4 nordon 



\section{Innovation og forbrugerkvalitet}

TemaNord 2006:541 
Innovation og forbrugerkvalitet

TemaNord 2006:541

(C) Nordisk Ministerråd, København 2006

ISBN 92-893-1348-X

Tryk: Ekspressen Tryk \& Kopicenter

Oplag: 200

Trykt på miljøvenligt papir som opfylder kravene i den nordiske miljøsvanemærkeordning.

Publikationen kan bestilles på www.norden.org/order. Flere publikationer på

www.norden.org/publikationer

Printed in Denmark

Nordisk Ministerråd

Store Strandstræde 18

1255 København K

Telefon $(+45) 33960200$

Fax (+45) 33960202

www.norden.org

\section{Nordisk Råd}

Store Strandstræde 18

1255 København K

Telefon (+45) 33960400

Fax (+45) 33111870

\section{Det nordiske samarbejde}

Det nordiske samarbejde er et af de ældste og mest omfattende regionale samarbejder i verden. Det omfatter Danmark, Finland, Island, Norge og Sverige samt Færøerne, Grønland og Åland. Samarbejdet styrker samhørigheden mellem de nordiske lande med respekt for de nationale forskelle og ligheder. Det øger mulighederne for at hævde Nordens interesser i omverdenen og fremme det gode naboskab.

Samarbejdet blev formaliseret i 1952 med Nordisk Råds oprettelse som forum for parlamentarikerne og regeringerne i de nordiske lande. I 1962 underskrev de nordiske lande Helsingforsaftalen, som siden har været den grundlæggende ramme for det nordiske samarbejde. I 1971 blev Nordisk Ministerråd oprettet som det formelle forum til at varetage samarbejdet mellem de nordiske regeringer og de politiske ledelser i de selvstyrende områder, Færøerne, Grønland og Åland. 


\section{Indhold}

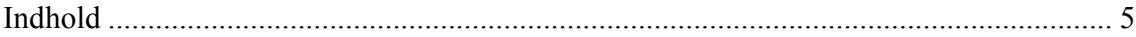

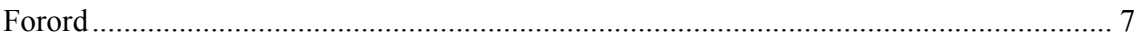

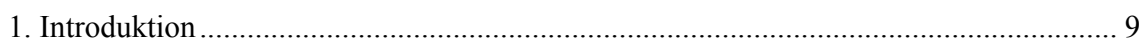

1.1 Debatten om brugerdrevet innovation...................................................... 9

1.2 Forbrugere, kvalitet og innovation .............................................................. 11

1.3 Formål med projektet............................................................................... 12

2. En model til analyse af forbrugernes kvalitetsopfattelse ....................................... 13

2.1 Redskaber til forbrugerdrevet innovation ............................................... 17

Gruppe 1: Indsigt i sammenhængen mellem mål, kvalitetsopfattelse og produktegenskaber............................................................... 24

Gruppe 2: Indsigt i udviklinger af sammenhængen mellem mål, kvalitetsopfattelse og produktegenskaber ........................................ 30

Gruppe 3: Kvantitative analyser af hvilke parametre der påvirker kvalitetsopfattelsen .......................................................................... 33

Gruppe 4: Indsigt i produkternes anvendelse ............................................... 37

Gruppe 5: Indsigt $\mathrm{i}$ indfrielse af forventninger og forbrugertilfredshed.............. 38

Gruppe 6: Løbende opsamling af forbrugerreaktioner................................... 41

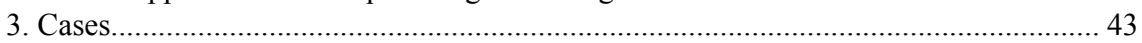

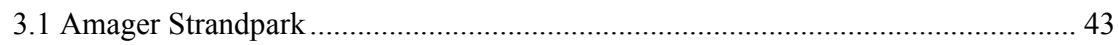

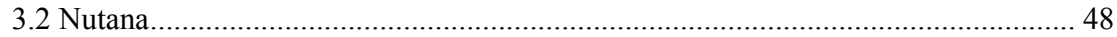

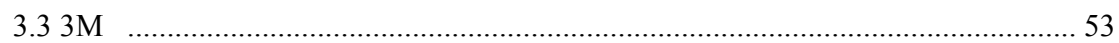

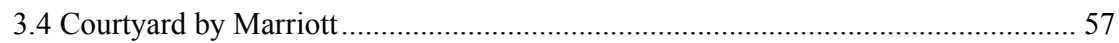

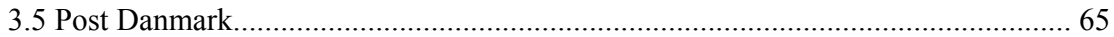

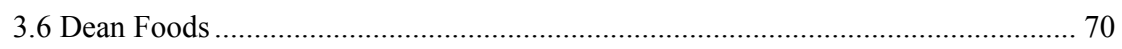

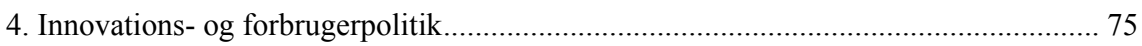

4.1 Innovationspolitik - begrundelse og instrumenter ........................................ 75

4.2 Teknologi- vs. forbrugerorienteret innovationspolitik ..................................... 77

4.3 Forbrugerpolitik og innovation ................................................................. 80

4.4 Muligheder for forbrugerpolitikken ......................................................... 82

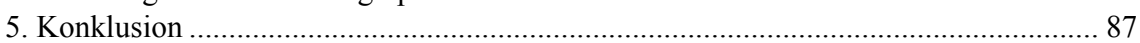

Sammenfatning: Innovation og forbrugerkvalitet ................................................ 89

Summary: Innovation Processes and Consumer Quality .......................................... 91

Yhteenveto: Innovaatioprosessit ja kuluttajalaatu .................................................... 93

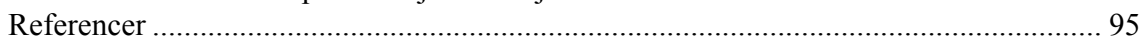

Appendiks A: Liste over interviews ................................................................... 99

Appendiks B: Interviewguides ................................................................... 101

Interview guide consumer policy ............................................................... 101

Appendiks C: Pjece om forbrugerdrevet innovation rettet til virksomheder................ 105 



\section{Forord}

Innovation knyttes ofte til teknologisk forskning og udvikling. Men innovation handler også om at opspore uopfyldte behov blandt forbrugerne og udvikle produkter og serviceydelser, som matcher disse behov. Det er dog ikke let at være innovativ eller udføre brugerdreven innovation. Det viser sig ved, at de fleste nye produkter ikke bliver en succes. Hermed har producenterne spildt ressourcer, og forbrugerne får ikke de produkter, de kunne ønske sig. Forbrugerinvolvering og brugerdreven innovation er emnet for denne rapport. Det undersøges, hvordan forbrugerne kan involveres i innovationsprocessen samt hvorledes kommunikationen mellem forbrugere og virksomheder kan forbedres.

I en tidligere rapport (Forbrugerkvalitet, TemaNord 2004:566) blev der sat fokus på virksomhedernes rolle i forbrugerpolitikken. Det skete ved at kortlægge og vurdere initiativer, som virksomheder og brancher har igangsat for at fremme forbrugerkvaliteten i form af god service og positive kundeforhold.

Formålet med dette projekt har været at sætte fokus på virksomhedernes rolle $\mathrm{i}$ forbrugerpolitikken ved at kortlægge og vurdere initiativer, som virksomheder og brancher har igangsat for at fremme forbrugerkvalitet og innovation. Det er håbet, at kortlægningen af initiativer til fremme af forbrugerkvalitet og innovation kan tjene som inspiration for virksomheder og brancheorganisationer.

Rapporten er finansieret af Nordisk Ministerråd og gennemført under EK Konsument. Professor, dr.oec.habil. Klaus G Grunert (Scientific Marketing Research) har været udreder på projektet.

Projektgruppen bestod af:

Annelise Fenger, Forbrugerstyrelsen, Danmark (projektleder)

Juha Eerikäinen, Konsumentverket, Finland

Eivind Stø, Statens institutt for forbrukerforskning, Norge

Karin Sjöberg, Jordbruksdepartementet, Sverige

Morten Brønnum Andersen, Forbrugerstyrelsen, Danmark 



\section{Introduktion}

\subsection{Debatten om brugerdrevet innovation}

Innovation bliver traditionelt ikke betragtet som et forbrugerpolitisk emne. Dette hænger sammen med, at innovation i den politiske debat mest bliver forbundet med teknologisk forskning og udvikling og dens anvendelse i form af nye produkter. Dette teknologiorienterede syn på innovation har rødder i nationaløkonomien, og de spørgsmål af politisk relevans, det rejser, handler om, hvordan man sikrer et tilstrækkeligt omfang af forskning og udvikling på offentlige forskningsinstitutioner og $\mathrm{i}$ erhvervslivet, og hvordan man sikrer transfer af ny teknologisk indsigt til potentielle brugere i virksomhederne.

Der findes dog et andet syn på innovation, som mest er fremherskende i erhvervsøkonomien: innovation er at opspore uopfyldte behov blandt de potentielle kunder i markedet, og udvikle produkter og serviceydelser, som matcher netop disse behov. Innovation i denne forstand kan, men behøver ikke at trække på ny teknologi - nyskabelsen kan ligge $i$, at man anvender kendte teknologier på en sådan måde, at der fremkommer et produkt, som forbrugerne vil opleve som nyt, og som gør noget for dem, som man ikke kunne få tidligere (Harmsen, Grunert, \& Declerck, 2000). De to syn på innovation, som tit kaldes for technology push og market pull, er illustreret i figur 1.
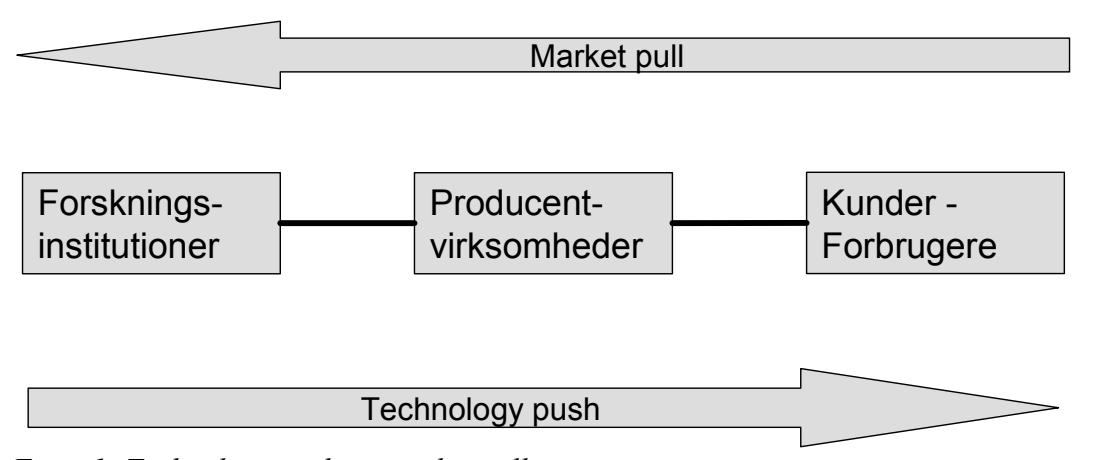

Figur 1: Technology push og market pull

Der er kommet meget mere fokus på den markedsbaserede innovation $\mathrm{i}$ den politiske debat om innovation i løbet af de seneste år. Der har været en stigende erkendelse af, at innovation som kilde til konkurrencekraft og velfærd ikke altid behøver at bunde i nye højteknologiske landvindinger, og at den markedsbaserede innovation i praksis er mindst lige så udbredt som den teknologibaserede. Den øgede opmærksomhed skyldes desuden, 
at man er ved at få øje på, at også den markedsbaserede innovation kan fremmes gennem egnede tiltag, både i virksomhederne og politisk.

Et nøgleord i denne debat har været brugerdrevet innovation. Begrebet bunder i en observation af, at der findes tilfælde, hvor kunderne i et marked ikke venter på, at producenterne lancerer nye produkter, men tager sagen $\mathrm{i}$ egen hånd og modificerer eller tilpasser de eksisterende produkter til de behov, som de føler (von Hippel, 1988). Der findes mange eksempler på industrielle markeder, hvor kunderne fx selv tilpasser maskiner og udstyr. Der findes også mange eksempler inden for it, hvor user communities modificerer software eller i enkelte tilfælde selv udvikler nye produkter (som operationssystemet Linux) helt forfra. Endeligt findes der også eksempler på konsumentvaremarkeder, hvor man fx hævder, at udviklingen af produktkategorien mountain bikes primært skyldes, at nogle cyklister selv begyndte at modificere almindelige cykler til brug uden for vejnettet. Alle eksempler har til fælles, at en producent så senere tog sagen op, industrialiserede produktionen og dermed kommercialiserede den innovation, som kunderne oprindeligt selv stod for.

Begrebet brugerdrevet innovation er dog i mellemtiden blevet udvidet en del og omfatter i dag ikke kun tilfælde, hvor brugerne tager initiativ til innovationen, men alle former for innovation, hvor brugeren er i centrum. Det inkluderer tilfælde, hvor producenten tager initiativ til innovationen, men involverer brugerne i udviklingsprocessen, og også tilfælde hvor producenten ikke engang selv involverer brugerne, men gør det ved hjælp af en tredjepart så som et markedsanalysebureau eller en trendspotter. Der findes også en hel stribe beslægtede begreber, som early customer integration (Gassmann \& Wecht, 2005), participatory design (Mayhew, 1999) og user-centred development (Ketola \& Ahonen, 2005). I nærværende rapport definerer vi brugerdrevet innovation som en proces mod udviklingen af et nyt produkt eller en ny serviceydelse, hvor en analyse og forstålse af brugernes behov og praferencedannelse spiller en afgørende rolle.

En bruger er ikke altid en forbruger. Mange produkter bliver udviklet til industrielle markeder, hvor de bliver købt af virksomheder, som bruger det som input i deres egen produktion. De fleste ældre dokumenterede eksempler på brugerdrevet innovation stammer faktisk fra sådanne markeder, hvor brugerne er nogen, der anvender de innovative produkter professionelt $\mathrm{i}$ deres eget arbejde. Brugerdrevet innovation af produkter og serviceydelser, som rettes mod private husholdninger, kan vi også kalde for forbrugerdrevet innovation. Det er denne type innovation denne rapport handler om - selv om vi vil bruge nogle eksempler fra industrielle markeder som illustration. 


\subsection{Forbrugere, kvalitet og innovation}

Denne sidste form for innovation, forbrugerdrevet innovation, peger på et felt, hvor forbrugerne og producenter har fælles interesser. Forbrugerne har en interesse i, at der kommer produkter på markedet, som opfylder deres behov. Producenterne har en interesse i at udvikle og introducere produkter, som vil falde $i$ forbrugernes smag. Betydningen af at et nyt produkt opfylder et hidtil udækket behov i markedet er velkendt og går igen i alle lærebøger om produktinnovation (Crawford, 1997; Fuller, 1994; Hart, 1996; Souder, 1989).

Alligevel er de fleste nye produkter, der bliver introduceret på konsumentvaremarkeder, fiaskoer - forstået på den måde at de ikke bliver en salgssucces og forsvinder fra hylderne igen i løbet af kort tid. Producenten har spildt ressourcer, og forbrugerne făr ikke de produkter, de kunne ønske sig.

Hvordan kan det være? Begrundelsen ligger i, at producenterne på konsumentvaremarkederne betjener et massemarked og har derfor ingen direkte kontakt med forbrugerne. Feedback fra forbrugerne kommer først, når produktet er lanceret på markedet - og når producenten allerede har investeret ressourcerne i udviklingen af produktet. Forbrugerdrevet innovation handler derfor om at få bygget kommunikation med forbrugerne ind i produktudviklingsprocessen, så nye produkter kan målrettes til forbrugerbehov, før de kommer på markedet (Cooper, 1984; Henard \& Szymanski, 2001).

Det er slet ikke let. 'Forbrugerbehov' er ikke noget, der er givet på forhånd, og forbrugerne kan for det meste ikke formulere ønsker om produkter, som endnu ikke er på markedet, medmindre der er tale om inkrementelle forbedringer af eksisterende produkter. Forbrugerbehov er latente, og de bliver til præferencer for produkter i en kompleks proces, hvor personlige, situationsbestemte og socioøkonomiske faktorer spiller en rolle, ud over de egenskaber som et muligt nyt produkt måtte have.

Den proces, hvori forbrugerne prøver at danne sig et indtryk af, hvad et nyt produkt vil kunne gøre for dem, kan betegnes som forbrugernes kvalitetsopfattelse, og producenternes forsøg på at skabe produkter, som forbrugerne vil tage til sig, kan betegnes som et forsøg på at skabe den rette kvalitet. Kvalitet er derfor et begreb, der kan bruges for at analysere, hvordan produktudviklingen hos producenten og udviklingen af produktpræferencer hos forbrugeren kan mødes. Kvalitet som brobyggende begreb mellem produktion og forbrug er blevet foreslået og brugt i forskellige sammenhænge, bl.a. i litteratur og praksis omkring kvalitetsledelse (Akao, 1990; Day, 1993; Griffin \& Hauser, 1993).

Et tidligere projekt under Nordisk Ministerråd (Grunert \& Andersen, 2004) har belyst, hvordan nordiske virksomheder prøver at forstå, hvordan forbrugere vurderer kvaliteten af deres produkter, så at produkterne kan forbedres på en måde, der falder i forbrugernes smag. Projektet viste, 
at mange virksomheder er meget famlende desangående. Nogle virksomheder kendte slet ikke til det hav af redskaber, der allerede findes, til at etablere kontakt mellem producent og forbruger, når der skal udvikles nye produkter. Andre brugte nogle af de mere enkle markedsanalyseteknikker som fokusgrupper. Generelt viste der sig et stort behov for kompetenceoverførsel mellem de virksomheder, som internationalt har udviklet spydspidskompetence $\mathrm{i}$ at analysere forbrugerbehov og integrere disse oplysninger i deres arbejde, og størstedelen af de nordiske virksomheder, der arbejder med produkter og serviceydelser rettet mod forbrugere.

Men match mellem forbrugerbehov og virksomhedens produktudvikling er ikke kun et spørgsmål om de rette teknikker til at fange forbrugernes røst. Den viden om forbrugerne, som man kan opnå på denne måde, skal også anvendes i virksomheden - den skal nyttiggøres i produktudviklingsprocessen, skal oversættes til tekniske produktspecifikationer, som kan bruges til design af produktionsprocesser, og skal sørge for, at ikke kun det fysiske produkt, men også kommunikation, distribution og service vil falde i forbrugernes smag. Forbrugerdrevet innovation er derfor en kompetence, som også i høj grad trækker på ledelsesmæssige og organisatoriske ressourcer i virksomheden, og at oparbejde denne kompetence er en langvarig og besværlig proces.

En forbedret kobling mellem forbrugernes behov og producenternes innovationsprocesser vil være til gavn for både forbrugere og producenter. Producenterne får mere succes med deres nye produkter. Forbrugerne bliver mere tilfredse med de produkter, de kan vælge imellem. Denne mulige win-win situation er udgangspunkt for nærværende projekt.

\subsection{Formål med projektet}

På baggrund af ovenstående har nærværende projektet to formål:

- At vise muligheder for hvordan producenterne kan øge forbrugerorienteringen i deres innovationsprocesser, gennem ibrugtagning af dertil egnede instrumenter og oparbejdning af de nødvendige kompetencer.

- At vise muligheder for hvordan forbrugerpolitikken kan bidrage til bedre forbrugerorienteret innovation i virksomhederne ved at skabe rammebetingelser, som letter kommunikationen mellem forbrugere og producenter.

Projektet bygger dermed bro mellem forbruger- og erhvervspolitik, herunder især innovationspolitik. 


\section{En model til analyse af forbrugernes kvalitetsopfattelse}

Før vi begynder at diskutere mulige redskaber, der kan bruges til at opnå en bedre forbrugerforståelse i en innovationsproces, kan det være nyttigt at opnå lidt mere klarhed om, hvad man egentlig gerne vil forstå. Grundlæggende vil en forbruger købe et nyt produkt, hvis forventningerne til produktet overstiger det offer, forbrugeren opfatter er forbundet med købet, i form af produktets pris. Denne grundantagelse holder på tværs af de fleste økonomiske, psykologiske og andre tilgange til forklaring af forbrugeradfærd. En forbruger er desuden mere tilbøjelig til at blive ved med at købe det pågældende produkt, hvis forventningerne faktisk bliver indfriet. Begge aspekter fanges af begrebet forbrugernes kvalitetsopfattelse: forventninger om produktets kvalitet afgør, om et nyt produkt bliver købt én gang, og indfrielse af forventninger afgør, om man køber igen. Når man har indsigt i, hvordan forbrugerne danner kvalitetsforventninger, før de køber, og hvordan de oplever kvalitet, efter de har købt, er man nået langt i opnåelsen af en forbrugerforståelse, der kan bruges i en innovationsproces.

Vi præsenterer derfor i det følgende en model af forbrugernes kvalitetsopfattelse, der fanger disse to aspekter. Modellen integrerer mange forskellige tilgange til analyse af forbrugeradfærd generelt og kvalitetsopfattelse specifikt og er blevet udviklet mest til analyse af kvalitetsopfattelse i forbindelse med fødevarer, men kan anvendes på alle konsumentvaremarkeder (Grunert, 2005a, b). Modellen præsenteres i figur 2. Vi kalder den bare Forbrugerkvalitetsmodellen.

Forbrugerkvalitetsmodellen har en vertikal og en horisontal dimension. Den vertikale dimension handler om, hvordan kvalitetsopfattelsen egentlig bliver til. Vi har den grundantagelse, at forbrugerne ser kvalitet $\mathrm{i}$ et produkt i den udstrækning, at de mener, at produktet er egnet til at opfylde deres mål. Mål skal her forstås helt bredt, nærmest som livsværdier som motiverer menneskelige valghandlinger på tværs af mange forskellige livssituationer (Rokeach, 1973; Schwartz \& Bilsky, 1987). En forbruger kan have overordnede mål som $\mathrm{fx}$ at have det sjovt i sit liv, at beskytte sin familie og at få udrettet noget professionelt. Disse mål vil ikke være relevante i alle tænkelige livssituationer, og deres vægt kan variere meget mellem situationer, men de vil, for denne forbruger, latent altid være til stede. I forbindelse med at forstå forbrugernes overordnede livsmål kan vi trække på omfattende forskning omkring menneskets livsværdier. 
Hvis sådanne mål motiverer valg af menneskelige handlinger på tværs af mange livssituationer, så vil de også motivere valg af produkter, herunder beslutninger om at købe nye produkter. Produkter bliver mere attraktive, hvis de opfattes som at kunne bidrage til opfyldelsen af livsmål. Det er denne opfattelse vi kalder kvalitetsopfattelse (Zeithaml, 1998).

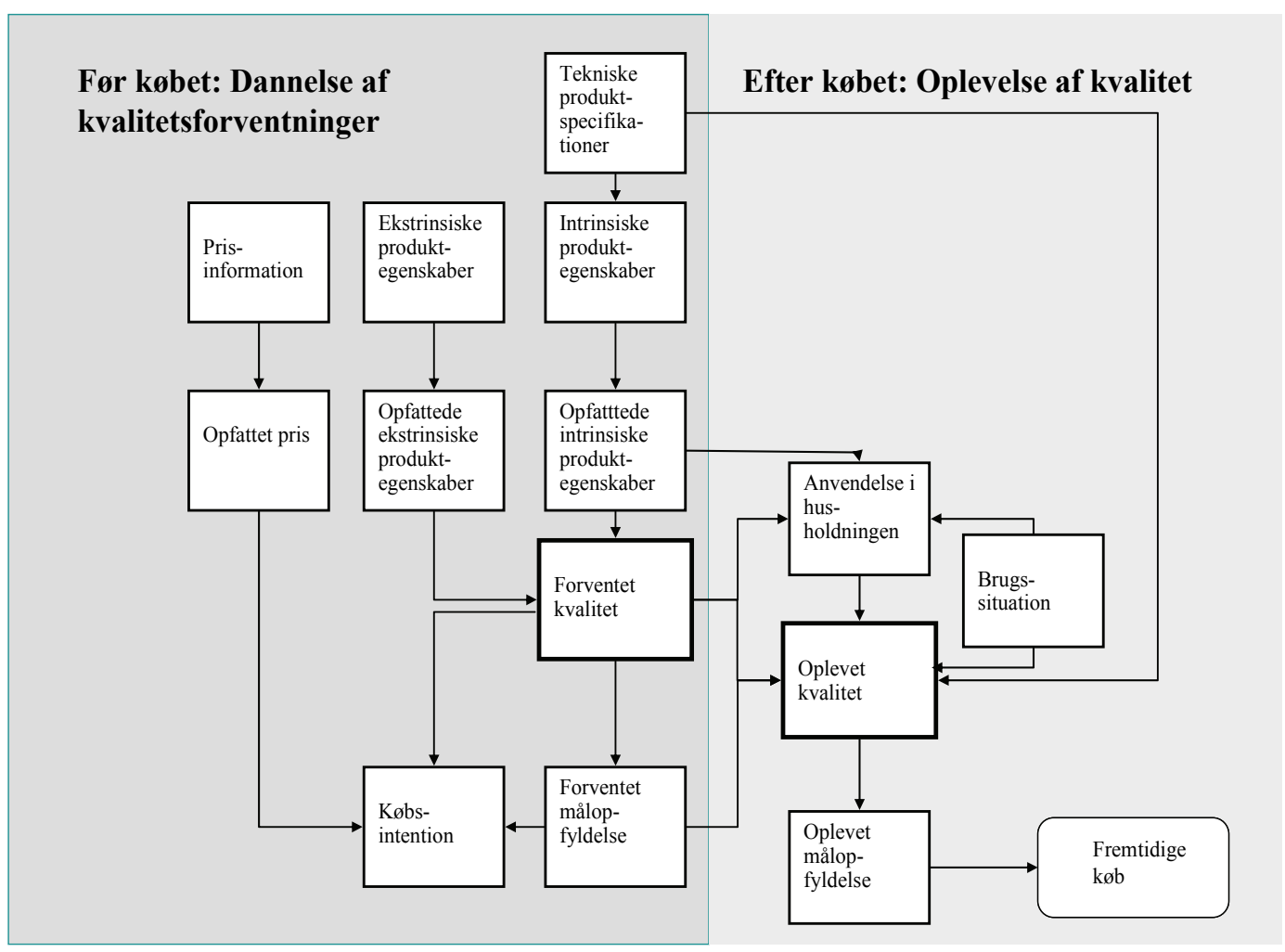

Figur 2: Forbrugerkvalitetsmodellen

Om et produkt er i stand til at bidrage til en forbrugers livsmål er ikke noget, der er iboende i produktet. Det er en opfattelse, som dannes i forbrugerens hoved, hvor han eller hun prøver at tolke sig frem til, om dette produkt mon vil kunne være relevant for netop hans/hendes mål. Kvalitetsopfattelsen dannes dermed ved at forbrugeren prøver at finde links mellem produktets opfattede egenskaber og vedkommendes livsmål. Jo flere sådanne links forbrugeren kan finde, jo mere kvalitet opfatter forbrugeren i produktet (Gutman, 1982).

Et eksempel kan illustrere tankegangen. Hvad gør en MP3 afspiller attraktiv for forbrugeren? Den kan spille musik, den er baseret på downloads, den er lille, den kan tages med overalt - det er nogle af en MP3 afspillers egenskaber. Nogle forbrugere ser i disse egenskaber måske nye muligheder for at opnå nogle af deres livsværdier. Vi kan forstille os en forbruger, der ønsker at nyde livet bl.a. ved at høre musik, og som samtidigt sætter meget pris på effektivitet og undgåelse af tidsspild. En sådan 
forbruger vil opfatte MP3en som en mulighed for at forene disse to værdier. Og han eller hun vil se kvalitet i en MP3 afspiller, hvis den har god lydkvalitet, bekvem håndtering og stor mobilitet.

Eksemplet viser tre ting. For det første, at kvalitet er et brobygningskoncept, som danner bro mellem produktets egenskaber og forbrugerens livsmål eller -værdier (Grunert, 2005a). Den skaber, i forbrugerens hoved, forbindelse mellem et konkret objekt, produktet, og nogle abstrakte, generelle mål. For det andet, at kvalitet i de fleste tilfælde er flerdimensionelt. I eksemplet har kvaliteten af MP3 afspilleren for denne forbruger tre dimensioner, som alle sammen kan være til stede i mere eller mindre grad. For det tredje, og det er det mest afgørende i nærværende projekts sammenhæng, at vi kan komme et stort skridt videre mod forståelsen af, hvordan forbrugere danner præferencer for nye, ukendte produkter, ved at forstå processen hvori forbrugere linker produkter til livsværdier. Fordi mens produkter kommer og går, så er livsværdier godt nok ikke uforanderlige, men dog ret stabile over tid, og også måden hvorpå forbrugeren tolker nye produkter i livsværdiernes lys kan karakteriseres ved en række stabile mekanismer.

Når man prøver at forstå, hvordan kvalitetsopfattelsen dannes på grund af opfattede produktegenskaber, er det almindeligt at skelne mellem intrinsiske og ekstrinsiske egenskaber (Olson \& Jacoby, 1972; Steenkamp, 1990). Intrinsiske egenskaber vedrører det fysiske produkt, ekstrinsiske egenskaber vedrører produktets brand, pris, reklamebudskaber, butikken hvor det bliver solgt - alle øvrige aspekter som forbrugeren muligvis bruger for at udlede en kvalitetsforventning. Forbrugeren kan måske tro, at en MP3 afspiller af mærket Sony har en særdeles god lydkvalitet. Denne form for slutninger er meget almindelige. Opdelingen viser også, at begrebet 'produktegenskaber' skal tolkes bredt her - det rummer alt, som forbrugeren muligvis kan finde på at bruge, når det handler om at danne sig et kvalitetsindtryk. Det er meget mere end det fysiske produkt, og det kan rumme aspekter, som ikke er helt under producentens kontrol, så som præsentationen af produktet i butikken.

Den opfattede kvalitet, baseret på opfattede produktegenskaber, holdes op mod den opfattede pris. Resultatet af dette trade-off vil resultere $\mathrm{i}$ en intention om at købe produktet eller ej. Vi kommer her ikke nærmere ind på, hvordan forbrugere opfatter priser, eller hvordan dette trade-off foregår, idet det ikke er centralt for nærværende projekt.

Inden for økonomisk teori er det almindeligt at skelne mellem søgekvaliteter, erfaringskvaliteter og troskvaliteter (Darby \& Karni, 1973; Nelson, 1970). Søgekvaliteter er kvaliteter, som forbrugeren med rimelig sikkerhed kan vurdere før købet, som fx MP3 afspillerens udseende (hvis denne indgår i denne forbrugers kvalitetsopfattelse). Erfaringskvaliteter er kvaliteter, som forbrugerne med rimelig sikkerhed først kan vurdere efter købet, nemlig gennem erfaring med produktet. Hertil hører MP3 afspillerens lydkvalitet og bekvemmelighed. Troskvaliteter er kvaliteter, 
som en almindelig forbruger aldrig med sikkerhed vil kunne vurdere tilstedeværelsen af, og som derfor er en trossag. Om en MP3 afspiller er blevet produceret på forsvarlig vis, fx ved at undgå miljøfarlige stoffer og børnearbejde, er noget, som den almindelige forbruger ikke har nogen mulighed for at finde ud af; han eller hun er tvunget til at beslutte sig for at tro på de oplysninger, der stilles til rådighed herom, eller for at lade være.

Et nyt produkt, som er karakteriseret mest ved søgekvaliteter, som $\mathrm{fx}$ et møbel, vil forbrugeren kunne vurdere før købet og derefter træffe en købsbeslutning på dette grundlag. Men de fleste produkter er kendetegnet ved erfarings- og troskvaliteter. Forbrugerne danner sig kvalitetsforventninger i eller før købssituationen, men disse er usikre, og kvalitetsopfattelsen vil kunne forandre sig efter købet. Det gælder især erfaringskvaliteter, hvor forbrugeren oplever kvaliteten efter købet, når produkter bliver brugt eller forbrugt, og hvor kvalitetsforventningen derfor kan af- eller bekræftes. Det gælder dog også troskvaliteter, hvor kvalitetsforventningen kan forandres efter købet på grund af ny information.

Denne forskel mellem kvalitetsforventning og kvalitetsoplevelse tilføjer Forbrugerkvalitetsmodellen en tidsdimension og udgør modellens horisontale dimension. Når der skal udvikles nye produkter og serviceydelser med udgangspunkt i, hvordan forbrugeren opfatter kvalitet, er det afgørende at forstå, hvordan kvalitetsopfattelsen forandres over tid. Kvalitetsopfattelsen før købet vil bestemme, om forbrugeren overhovedet giver et nyt produkt en chance. Men oplevelsen med produktet bagefter vil afgøre, om forbrugeren stadigvæk mener, at produktet bidrager til vedkommendes livsværdier, om produktet skal roses eller klages over, og ikke mindst om produktet købes igen eller forsvinder fra hylderne.

Forståelsen af kvalitetsopfattelsen efter købet kompliceres af, at denne ikke kun afhænger af produktets egenskaber. Den afhænger i høj grad af, hvordan produktet bruges af forbrugeren. Om MP3 afspilleren bruges mest, mens man jogger eller i en larmende undergrundsbane, kan føre til helt forskellige opfattelser af dens lydkvalitet og bekvemmelighed. Man kan sige, at kvalitetsforventningen opstår i interaktion mellem forbrugeren og det sæt informationer, forbrugeren er eksponeret for før og under købet, mens kvalitetsoplevelsen opstår i interaktion mellem forbrugeren og de anvendelser, han/hun udsætter produktet for.

Redskaber til forbrugerdrevet innovation skal hjælpe med at bygge udviklingen af nye produkter og serviceydelser på en forståelse af, hvordan forbrugerne danner kvalitetsforventninger til de nye produkter, og hvordan de vil opleve kvaliteten af produkterne, når de er blevet købt. Det er denne type redskaber det næste afsnit handler om. 


\subsection{Redskaber til forbrugerdrevet innovation}

Krav til redskaberne

Vi kan bruge Forbrugerkvalitetsmodellen til at formulere fem spørgsmål, som redskaberne til fremme af forbrugerdrevet innovation skal kunne give svar på. Ikke alle redskaber vil kunne give svar på alle spørgsmål tværtimod skal vi senere se, at et enkelt redskab typisk kun giver svar på et eller to af spørgsmålene, og at der derfor kræves en kombination af forskellige redskaber - men vi kan bruge disse spørgsmål som relevanskriterium til bedømmelsen af de mange forskellige redskaber, der potentielt kan finde anvendelse. Vi formulerer alle spørgsmål i henhold til en hypotetisk produktkategori, produkt $X$, hvor der er en producent, der sigter mod forbrugerdrevet innovation.

Hvordan udledes kvalitetsopfattelsen af $\mathrm{X}$ af forbrugernes overordnede livsmål og -værdier?

Det handler her om at forstå, hvad der grundlæggende motiverer forbrugerne til at efterspørge denne type produkt. Hvad er de overordnede livsværdier eller livsmål, som en forbruger vil kunne finde på at knytte til denne type produkt, og hvad betyder det for de kvalitetsdimensioner, der vil opfattes som relevante?

Hvordan kommunikerer produkt X kvaliteten til forbrugeren?

Med andre ord, hvilke egenskaber ved produktet gør, at produktet opfattes som at kunne bidrage til forbrugerens livsmål, og som dermed afgør om produktet opfattes som værende af højere eller lavere kvalitet? Dette er specielt vigtigt for nye produkter, hvor forbrugeren ikke kan bygge på sine egne og tidligere erfaringer med lignende produkter. Det er ikke tilstrækkeligt, at produktet har en eller anden indbygget objektiv kvalitet - den skal kommunikeres til forbrugeren gennem produktets design, produktets udstråling, produktets konkrete og synlige egenskaber.

Hvordan kan information om X støtte kvalitetsopfattelsen?

Det er selvfølgelig ikke kun selve produktet, der kommunikerer kvaliteten til forbrugeren, men også dets emballage, dets reklamemateriale, dets PR, dets salgsmæssige omgivelser m.m. Igen er effekten af denne kommunikation specielt vigtig ved førstegangskøb af nye produkter, hvor forbrugeren ikke kan trække på tidligere erfaringer, men vi har tidligere set, at information om produktet bliver ved med at have stor betydning for kvalitetsopfattelsen i de tilfælde, hvor der er tale om troskvaliteter, dvs. kvalitetsaspekter som ikke kan direkte erfares af forbrugeren og som derfor skal kommunikeres, også efter købet. Det gælder for eksempel sundhedseffekter af fødevarer, miljøegenskaber ved VVS udstyr og dyrevenlighed ved kosmetikprodukter. 
Hvordan påvirker måden, $\mathrm{X}$ anvendes på, kvalitetsopfattelsen?

Opfattelsen af produktets egnethed til at opfylde ens livsværdier og produktets kvalitet er, som tidligere argumenteret, påvirket af, hvordan og til hvad produktet anvendes. Det er derfor vigtigt at få indsigt i de forskellige måder, forbrugerne bruger X på, og hvordan disse influerer på kvalitetsopfattelsen.

Hvordan opleves $\mathrm{X}$ under brug?

Dette er simpelthen spørgsmålet om den oplevede kvalitet. Bliver forventningerne indfriet? Er forbrugeren tilfreds eller skuffet? Hvilke aspekter af produktet opleves som tilfredsstillende, hvilke som mindre tilfredsstillende? Spørgsmålet giver naturligvis kun mening for produkter, som allerede er fremstillet (i hvert fald som prototype), men kan give værdifulde oplysninger om produktforbedringer.

Vi betragter et redskab som egnet til at støtte forbrugerdrevet innovation, hvis det kan give svar på mindst et af disse fem spørgsmål. Samtidigt kan disse fem spørgsmål bruges til at klassificere redskaberne, alt afhængig af hvilke af disse spørgsmål de kan give svar på. Ud over variation i den type oplysninger redskaberne genererer, så er der også stor variation i den bagvedliggende teori eller den metodiske tilgang, der anvendes. Redskaberne kan derfor også karakteriseres og klassificeres efter den brugte metodiske tilgang. Før vi kommer til beskrivelsen af selve redskaberne, diskuterer vi derfor i næste afsnit først en række dimensioner, der fanger de forskellige metodiske tilgange.

Typer af redskaber: Dimensioner der fanger de vigtigste forskelle

Som nævnt ovenfor er forbrugerorientering hos producenterne både et spørgsmål om instrumenter og om kompetencer, der tillader at nyttiggøre disse instrumenter.

Litteraturen omkring markeds- eller brugerdrevet produktinnovation byder på et hav at redskaber og mange gode råd i forbindelse med brugerinvolvering. Nogle af disse redskaber er velkendte og indgår i mange virksomheders værktøjskasse, fx fokusgrupper, segmenteringsanalyser, brugerpaneler, koncepttests, og testmarkedsføring. Andre er forholdsvis nye og derfor ikke så udbredt endnu i deres anvendelse, fx antropologisk inspirerede observationsmetoder eller metoder, der bygger på brug af metaforer. Endnu andre bryder grænsen af det man almindeligvis kalder markedsanalyser og sigter mod at etablere eller ligefrem institutionalisere en egentlig dialog mellem producent og (for)bruger. Det sidste er især blevet brugt på industrielle markeder (Biemans, 1991; von Hippel, 1978), hvor det altså ikke er forbrugere, der er kunderne, mens eksempler på konsumentvaremarkeder har været mere sjældne.

De vigtigste forskelle mellem disse redskaber kan fanges i fem dimensioner, som hver især har implikationer for, hvordan og til hvad redskabet kan bruges i virksomheden: 
- Beskrivende vs. forklarende

- Reduktionistisk vs. kontekstorientret

- Dialog vs. envejskommunikation

- Direkte vs. indirekte kontakt mellem virksomhed og forbruger

- Ad hoc vs. institutionaliseret

Beskrivende vs. forklarende. Gennem et observationsstudie har vi fx fundet ud af, at mange forbrugere køber frisk kød og fryser det ned, så snart de kommer hjem. Vi har dermed beskrevet et element af forbrugeradfærd i forbindelse med køb og anvendelse af kød. Beskrivelsen rejser straks et spørgsmål: hvorfor køber forbrugeren ikke det frosne kød, som findes i supermarkedet, når det alligevel skal fryses ned derhjemme? Vi har beskrevet, men endnu ikke forklaret dette element af forbrugeradfærd. Yderligere undersøgelser viser måske, at forbrugeren tror, at kød, som sælges frosset, er af mindre kvalitet, og at det er mere vanskeligt at bedømme kvaliteten i supermarkedet, når kødet er frosset, end når det er frisk.

I eksemplet rejser beskrivelsen et spørgsmål, som forklaringen giver svar på. Forklaringen kan så være udgangspunkt for forbrugerdrevet produktudvikling, fx gennem en forbedret kvalitetsmærkning af frosset kød eller salg af fersk kød i frys-det-selv-ned pakninger.

En stor del af de forbrugeroplysninger, som virksomheder jævnligt indsamler, er beskrivende. Det gælder salgstal, præferencemålinger for eksisterende produkter eller nye produktkoncepter, tilfredshedsmålinger og størstedelen af observationsstudier. Denne type oplysninger kan rejse vigtige spørgsmål - hvorfor kan forbrugerne lide A men ikke $\mathrm{B}$, hvorfor bruger de ikke produktet korrekt, hvorfor går salget af produkt $\mathrm{X}$ ned. Nogle gange kan genereringen af denne type spørgsmål være nok som input til virksomheden, som så prøver at finde svarene internt, fx gennem brainstorming i produktudviklingsgruppen. Tit vil det dog være sådan, at man går et trin videre og ønsker også oplysninger om svarene. Det kan være gennem en ny undersøgelse - fx kombinerer man ofte observationsstudier med et efterfølgende trin, hvor man går i dialog med brugerne. Nogle værktøjer tillader dog at gå efter beskrivelsen og forklaringen samtidigt, fx når man anvender en model til måling af forbrugertilfredshed som samtidigt estimerer vægten af væsentlige potentielle forklaringsfaktorer for tilfredsheden (et eksempel på det følger senere).

Når man prøver at finde forklaringer på visse aspekter af forbrugeradfærd hjælper det, at det anvendte instrument bygger på teori. En teori siger, kort sagt, hvor man skal lede efter forklaringer for noget. Forbrugeradfærd er et teoretisk ganske meget udforsket område, selv om den teoretiske indsigt ofte ikke når at komme med i anvendelsen af instrumenter, der skal generere oplysninger til forbrugerdrevet innovation. Der er dog en række undtagelser, som vi kommer ind på senere. 
Reduktionistisk vs. kontekstorienteret. Når vi ønsker at forstå forbrugerkrav og -præferencer i forhold til et produkt som vaskemaskiner, kan vi fx lave dybdeinterviews med 3-4 familier, besøge dem i deres hjem, observere deres adfærd i forbindelse med vask af tøj, stille nye spørgsmål til dem på baggrund af det observerede osv. Vi opnår på denne måde en dybtgående forståelse af disse familiers krav til vaskemaskiner - ikke kun, hvilken type vaskemaskine de foretrækker, men også hvordan vask indgår i familiens hverdag, hvilken rolle familiemæssige og jobmæssige faktorer spiller, hvilken betydning de huslige omgivelser har, familiens tøjstil og mange andre ting. Vi vil kunne forstå disse forbrugeres krav til vaskemaskiner ud fra hele den kontekst, hvori vask og dermed brug af vaskemaskiner indgår for disse familier. En sådan metode kaldes derfor kontekstorienteret.

I skarp modsætning til dette vil man kunne lave en undersøgelse, hvor vi udelukkende ser på, hvordan enkelte produktegenskaber, fx antal programmer og længde af vaskeforløbet, påvirker forbrugerpræferencer. Vi ignorerer konteksten, men til gengæld vil vi med stor præcision kunne sige, hvor meget det betyder for forbrugerpræferencen at vaskelængden stiger med 10 minutter. En sådan fremgangsmåde kalder vi reduktionistisk, fordi vi reducerer virkelighedens kompleksitet til nogle få aspekter, som vi belyser ud fra et krav om præcision og kvantificering.

Der knytter sig i samfundsvidenskaberne store videnskabs- og erkendelsesteoretiske diskussioner til disse to fremgangsmåder, deres fordele og ulemper. Men ud fra en pragmatisk tilgang, hvor vi ønsker at vurdere redskaber, der kan hjælpe i forbrugerdrevet innovation, er det åbenlyst, at begge tilgange har fordele og ulemper og supplerer dermed hinanden. Det er selvfølgelig vigtigt som input $\mathrm{i}$ en innovationsproces at forstå konteksten, hvori produktet indgår $\mathrm{i}$ forbrugerens husholdning, fordi det giver ikke kun indsigt i de krav, en forbruger stiller til et produkt, men gør dem også forståelige ud fra denne forbrugers livssituation og livshistorie. Dette kan give inspiration ikke kun til produktforbedringer, men muligvis ligefrem til udviklingen af helt nye produkter, fordi man erkender, at de eksisterende ikke synes at løse de problemer, som forbrugerne virkelig føler. Til gengæld er de fremkomne oplysninger tit ikke særlige præcise og desuden typisk baseret på et fåtal af observationer, og det vil derfor tit være hensigtsmæssigt at supplere med en mere reduktionistisk undersøgelse, som kan baseres på flere observationer og som tillader kvantificering af $\mathrm{fx}$ den relative betydning af en række potentielle egenskaber af et nyt produkt. Vi gennemgår derfor senere eksempler på både reduktionistiske og kontekstorienterede redskaber.

Dialog vs. envejskommunikation. Langt størstedelen af traditionel markedsanalyse er envejskommunikation. Forbrugerne bliver udspurgt, interviewet eller observeret, tit ved hjælp af en markedsanalysevirksomhed, og den opdragsgivende virksomhed får resultaterne tilsendt. Resultaterne kan så indgå $\mathrm{i}$ en innovationsproces, som ender med nye produkter, 
som forbrugerne så kan til- eller fravælge fra hylderne, men en egentlig tovejskommunikation opstår der ikke.

Der er, også inden for traditionel markedsanalyse, undtagelser. Virksomheden kan oprette forbrugerpaneler, hvor man er i kontakt med de samme forbrugere over en længere periode. Det betyder ikke nødvendigvis, at der faktisk opstår dialog - som jo forudsætter, at virksomheden vender tilbage til forbrugerne i panelet med noget, som tager udgangspunkt i det input, forbrugerne kom med de sidste gange. Men muligheden er der. Ellers er dialog mellem virksomhed og forbruger tit noget der er forbrugerinitieret, mest $\mathrm{i}$ forbindelse med klager eller anmodninger om råd og vejledning, hvor en forbruger henvender sig og får svar fra virksomheden. Denne form for dialog har ikke som primært formål at fremskaffe oplysninger, der kan bruges i forbrugerdrevet innovation - det primære formål er jo netop at behandle klager eller give råd og vejledning. Men virksomheden kan vælge at udnytte de fremkomne oplysninger i innovationsøjemed, typisk med henblik på produktforbedringer. Hvis virksomheden sætter pris på denne type oplysninger kan den opmuntre forbrugerne til at tage initiativ til denne form for dialog, fx ved at henvise til hotlines, hvor man kan ringe til, og/eller ved at installere webbaserede dialogsystemer.

Direkte vs. indirekte kontakt. Der er tradition for at outsource kontakten til forbrugerne, dvs. det er ikke producenten selv, der tager kontakt til forbrugerne, men en tredje part, som er hyret til formålet. I de mest almindelige tilfælde er der tale om et markedsanalysebureau, der så organiserer fokusgrupper, gennemfører interview og udsender spørgeskemaer. Producenten formulerer typisk i dialog med markedsanalysebureauet de spørgsmål, han vil have svar på, og markedsanalysebureauet afleverer en rapport, typisk kombineret med en præsentation af resultaterne. Der findes også andre aktører, der påtager sig denne agentrolle - det kan være en trendspotter, som gennem egen interaktion med forbrugere 'opsamler' trends og videreformidler denne viden til producenterne, typisk kombineret med et forløb hvor trendspotteren og virksomheden i fællesskab prøver at relatere trendene til netop denne virksomheds produkter. Der findes også konsulentvirksomheder specialiseret i innovation, som gennemfører forløb med forbrugerinvolvering, fx gennem observationsstudier, som en del af deres ydelsespakke. Endeligt gennemfører reklamebureauer tit af egen drift projekter der involverer forbrugerkontakt, som så indgår i drøftelserne mellem reklamebureau og den virksomhed, der køber kommunikationsydelser.

Der er principielt ikke noget til hinder for, at producenten selv organiserer sin kontakt til forbrugerne uden yderligere hjælp fra en tredjepart. Egentlige dialogbaserede redskaber (se ovenfor) er tit noget producenten selv organiserer, mens de mere traditionelle former for markedsanalyse for det meste bliver overladt til specialister uden for huset. Spørgsmålet om direkte vs. indirekte kontakt kan godt sættes i relation til den generel- 
le diskussion om outsourcing. Den fremherskende mening er, at virksomheder skal koncentrere sig om deres kernekompetencer og outsource resten. Når så mange virksomheder overlader deres kontakt til forbrugerne til andre er det et tegn på, at forståelse af forbrugerbehov og dens nyttiggørelse i innovationsøjemed ikke betragtes som en kernekompetence.

Ad hoc vs. institutionalisering. Når en producent tager et redskab i brug for at etablere kontakt med forbrugerne eller skaffe oplysninger om forbrugere i forbindelse med et innovationsprojekt, er der i mange tilfælde tale om et ad hoc foretagende, dvs. noget der slutter, når de ønskede oplysninger er fremskaffet. En virksomhed, der prioriterer forbrugerkontakten i innovationsøjemed højt, vil dog kunne finde på at institutionalisere denne kontakt på en sådan måde, at den bliver varig - og dermed frakoblet det enkelte innovationsprojekt. Nogle af de tidligere omtalte dialogorienterede redskaber, så som brugerpaneler eller brug af hotlines, er eksempler på sådanne institutionaliserede former for forbrugerkontakt. En anden mulighed, som vi vender tilbage til, er etableringen af en afdeling i virksomheden, som skal hente forbrugernes røst ind i organisationen - såkaldte consumer affairs departments.

I forbindelse med brugerdrevet innovation er der desuden en vigtig diskussion, som går på, om nogle redskaber er mere egnede som input til inkrementelle produktforbedringer, mens andre er mere egnede som input til egentlige radikale innovationer. Der findes i en del af litteraturen for eksempel det argument, at alle redskaber, der bygger på verbal input fra forbrugerne, lider af, at forbrugernes sprogbrug er relateret til de eksisterende produkter, hvorved input, der kan bruges til mere radikale innovationer, ikke opnås (Leonard, 1995). Vi er ikke enige i en sådan enkel opdeling og har derfor også udeladt at bruge det som yderligere kriterium her, fordi vi mener, at dette afhænger i meget højere grad af redskabernes anvendelse end af deres iboende egenskaber. Vi vil dog tage spørgsmålet op i forbindelse med beskrivelsen af de enkelte redskaber. 
Tabel 1: De vigtigste redskaber

\begin{tabular}{|c|c|c|c|c|c|c|c|}
\hline & Udbytte & Metoder & $\begin{array}{l}\text { Beskrivende/ } \\
\text { forklarende }\end{array}$ & $\begin{array}{l}\text { Reduktio- } \\
\text { nistisk/ } \\
\text { kontekst- } \\
\text { orienteret }\end{array}$ & $\begin{array}{l}\text { Dialog/ } \\
\text { envejs }\end{array}$ & $\begin{array}{c}\text { Direkte/ } \\
\text { indirekte }\end{array}$ & $\begin{array}{c}\text { Ad hocl } \\
\text { institutio- } \\
\text { naliseret }\end{array}$ \\
\hline 1 & $\begin{array}{l}\text { Indsigt i sammenhængen } \\
\text { mellem mål, kvalitetsopfattelse } \\
\text { og produktegenskaber }\end{array}$ & & $B / F$ & $\mathrm{~K}$ & $\mathrm{E}$ & I & A \\
\hline 2 & $\begin{array}{l}\text { Indsigt i udviklinger af sam- } \\
\text { menhængen mellem mål, } \\
\text { kvalitetsopfattelse og produkt- } \\
\text { egenskaber }\end{array}$ & $\begin{array}{l}\text { Scenarieteknikker, } \\
\text { lead user metode, } \\
\text { brugerpaneler }\end{array}$ & $\mathrm{F}$ & $\mathrm{R} / \mathrm{K}$ & $\mathrm{D}$ & D & I \\
\hline 3 & $\begin{array}{l}\text { Kvantitative analyser af hvilke } \\
\text { parametre der påvirker kvali- } \\
\text { tetsopfattelsen }\end{array}$ & $\begin{array}{l}\text { Conjoint analyse, } \\
\text { category appraisal }\end{array}$ & $\mathrm{F}$ & $\mathrm{R}$ & $E$ & I & A \\
\hline 4 & $\begin{array}{l}\text { Indsigt i produkternes anven- } \\
\text { delse }\end{array}$ & Empatisk design & B & K & $\mathrm{D}$ & $\mathrm{D} / \mathrm{l}$ & A \\
\hline 5 & $\begin{array}{l}\text { Indsigt i indfrielse af forvent- } \\
\text { ninger og forbrugertilfredshed }\end{array}$ & $\begin{array}{l}\text { Tilfredsheds-, } \\
\text { loyalitetsmålings- } \\
\text { systemer, fx ECSI, } \\
\text { RelationScore }\end{array}$ & $\mathrm{F}$ & $\mathrm{R}$ & $\mathrm{E}$ & I & $A / I$ \\
\hline 6 & $\begin{array}{l}\text { Løbende opsamling af forbru- } \\
\text { gerreaktioner }\end{array}$ & $\begin{array}{l}\text { Complaint man- } \\
\text { agement, con- } \\
\text { sumer affairs } \\
\text { departments }\end{array}$ & B & K & D & D & I \\
\hline
\end{tabular}

De vigtigste grupper af redskaber

Ud fra de ovenfor formulerede krav til redskaber, der skal kunne bidrage til forbrugerdrevet innovation, og de fem dimensioner, der fanger de vigtigste metodiske forskelle, kan vi nu identificere de vigtigste grupper af redskaber. I tabel 1 nævner vi seks grupper af redskaber, der adskiller sig både med hensyn til hvilke spørgsmål i forbindelse med forbrugerdrevet innovation de kan give svar på, og hvordan de er placeret i forhold til de metodiske dimensioner (for andre lister og gennemgange af redskaber, se fx Holt et al.; Nijssen \& Lieshout, 1995; Tidd \& Bodley, 2002; van Kleef et al., 2005). Vi gennemgår i det følgende disse redskaber - hvad grundidéen er, hvordan de virker, hvad man kan bruge dem til og hvad ikke. I næste hovedafsnit følger der så en række cases, hvor nogle af redskaberne er blevet taget $i$ anvendelse.

Redskabernes rolle $\mathrm{i}$ et produktudviklingsforløb

Udviklingen af et nyt produkt opfattes almindeligvis som bestående af en række faser, som eksempelvis kan betegnes som identificering af muligheder, udvikling, optimering og lancering (Urban \& Hauser, 1993). I praksis vil de forskellige faser ikke altid være skarpt adskilt, og deres betegnelser er selvfølgelig vilkårlige, men grundlæggende indeholder al produktinnovation et forløb, hvor en idé efterhånden bliver modnet, indtil det nye produkt lanceres på markedet. Det er vigtigt at fastholde, at vi i det følgende kun omtaler redskaber, som kan bruges i begyndelsen af 
produktudviklingsforløbet, hvor det handler om at identificere muligheder for nye produkter eller produktforbedringer gennem en øget forbrugerforståelse og -involvering. Der findes også mange redskaber til at skabe links til forbrugerne senere hen i forløbet, når man $\mathrm{fx}$ har udviklet prototyper af det nye produkt og skal teste forbrugernes reaktion på det. Disse teknikker vil ikke blive omtalt her. Figur 3 (adapteret fra van Kleef et al., 2005) giver et meget kort overblik over andre teknikker, der bruges senere hen i udviklingsforløbet, og henviser til en række kilder, hvis man vil fordybe sig i disse.

Gruppe 1: Indsigt i sammenhcengen mellem mål, kvalitetsopfattelse og produktegenskaber

Her har vi grupperet en række metoder, som alle sammen kan give indblik i, hvordan forbrugere opfatter kvalitet, og hvordan denne kvalitetsopfattelse hænger sammen med deres overordnede mål eller livsværdier. Det er alle sammen kvalitative metoder, som bevarer kontekst og kompleksitet. De er i forskellig grad udbredt som værktøjer, der bruges i dag, og de fleste (hovedundtagelsen er ZMET) kan købes også i de nordiske lande som ydelser hos konsulentbureauer og markedsanalysevirksomheder.

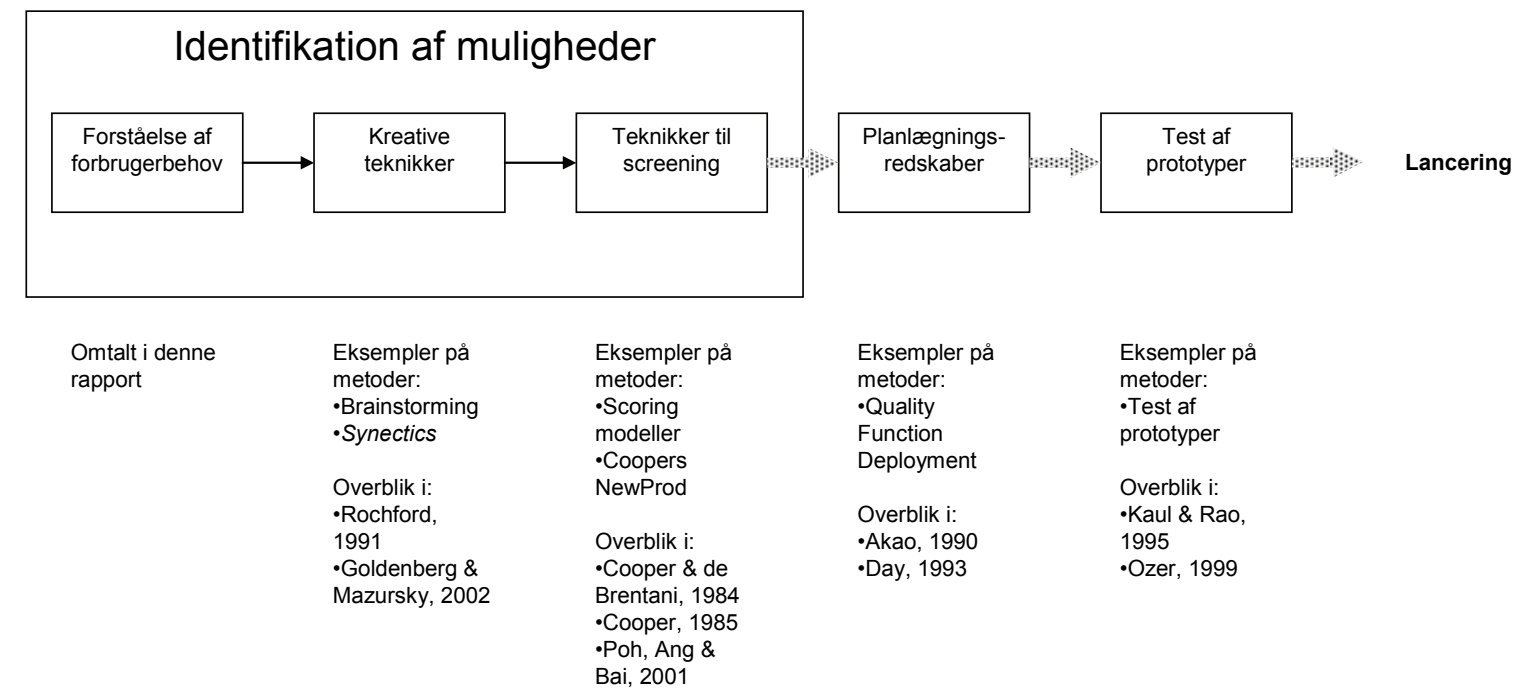

Figur 3: Redskaber i produktudviklingsforløbet

Adapteret fra van Kleef, van Trijp \& Luning, 2005

\section{Fokusgrupper}

Fokusgrupper er nok det mest udbredte instrument overhovedet, når det gælder om at inddrage forbrugerne i en innovations- eller produktudviklingsproces (McQuarrie \& McIntyre, 1986). Grundprincipperne er enkle: man samler et antal forbrugere fra målgruppen, typisk mellem 8 og 12, i et par timer, og gennemfører en fælles diskussion, som bliver ledt af en 
diskussionsleder uddannet til formålet. Diskussionslederen følger typisk en spørgeguide, som er blevet udarbejdet i samarbejde med den opdragsgivende virksomhed. Her kan man principielt rejse alle tænkelige emner, men tit starter man med generelle forbrugs- og købsvaner inden for en bestemt kategori, for derefter at gå over til mulige nye produkter, hvor man kan bruge produktkoncepter, dummies og samples som stimuli for at fodre diskussionen. Hele diskussionen bliver typisk optaget på videobånd med henblik på den senere analyse. Der findes et utal af varianter - rekrutteringen kan fx styres af en allerede eksisterende segmenteringsanalyse, så man sikrer sig, at kun de meste innovative forbrugere deltager i diskussionen, og i gennemførelsen kan man indbygge en række opgaver, som deltagerne løser individuelt, og som kan danne grundlag for videre diskussion. Her bruges der tit teknikker, som prøver at fange det ikkeverbale, som fx collager, og teknikker, der prøver at imødegå tendensen til at komme med udtalelser, der opfattes som socialt ønskelige, fx de såkaldte projektive teknikker, hvor man bliver bedt at udtale sig ikke om en selv, men om hypotetiske andre forbrugere.

Fokusgruppernes brede anvendelse skyldes især, at de er nemme at gennemføre og forholdsvis billige, og så giver de et første indblik i forbrugernes tænkemåde og sprogbrug. Det i sig selv kan være en eye opener for folk i en virksomhed, som ikke har tradition for at være i kontakt med forbrugerne, og som i sin dagligdag måske koncentrerer sig mest om kontakten med sine direkte kunder (Calder, 1977). Der er dog en potentiel væsentlig metodisk fordel i fokusgrupper, nemlig at udtalelserne kommer i stand i social interaktion mellem deltagerne. Når man beder forbrugerne om at udtale sig ikke kun om deres nuværende forbrugsmønstre og vaner, men også om hypotetiske situationer og produkter, så vil deres holdninger og meninger tit ikke være særlig stabile. Hvis der er anledning til at tro, at den sociale interaktion - med venner, familie, kollegaer - vil spille en væsentlig rolle $\mathrm{i}$ forbrugernes holdningsdannelse til den produktkategori man arbejder med også i forbrugernes 'virkelige' liv, så kan det tale for, at man analyserer deres holdninger ligeledes i en social situation som fx en fokusgruppe (Grunert, 1990; Mangold, 1960).

Der er dog også en række ulemper. Generaliserbarheden af resultaterne af en fokusgruppe er altid tvivlsom, og den kan derfor som udgangspunkt ikke bruges som andet end som inspirationskilde. Man får desuden kun indsigt i den del af forbrugernes tænkemåde, som de kan og ønsker at verbalisere gennem sprog, selv om brug af collager m.m. kan afbøde dette lidt. Men hvis der er anledning til at tro, at produktgruppen i høj grad karakteriseres af spontan og følelsesmæssig adfærd, burde en fokusgruppe nok suppleres med andre metoder.

Stort set alt kan diskuteres i en fokusgruppe, men i forhold til Forbrugerkvalitetsmodellen er det især den vertikale dimension, der kan opnås indsigt $i$. Forbrugerne kan let $\mathrm{i}$ en fokusgruppe beskrive de mål de har med at bruge et produkt, de kan beskrive hvad de opfatter som god kvali- 
tet, og hvilke egenskaber der for dem signalerer høj kvalitet. Der kan også opnås indsigt i typiske anvendelsessituationer.

\section{Dybdeinterviews, iscer repertory grid og laddering}

Dybdeinterviews er alternativet til fokusgrupper, når man ikke bryder sig om den sociale interaktion mellem deltagerne eller i hvert fald mener, at man kan undvære den, og i stedet vil gå mere i dybden med den enkelte forbruger. Også her er der et hav af varianter, men vi vil mest henvise til to metoder, tit brugt i flæng, som er særligt egnede til at fremkalde forbrugernes underliggende behov eller mål og den måde, de bliver relateret til konkrete produktegenskaber. Metoderne har en særlig teoretisk baggrund, kaldt theory of personal constructs, som blev grundlagt af den engelske psykolog Kelly (Kelly, 1955) og som stadigvæk har mange tilhængere, hvilket en søgning på nettet vil afsløre. En af Kellys grundhypoteser var, at mennesker finder mening i deres omgivelser ved at kategorisere det de ser i et sæt af 'bipolare konstrukter.' 'Dyrt - billigt' er fx et bipolart konstrukt, som forbrugere anvender for at kategorisere produkter. Sådanne konstrukter findes på flere abstraktionsniveauer, dvs. de danner et hierarki, og jo længere vi kommer op i hierarkiet, jo mere nærmer vi os menneskets grundlæggende behov, mål og værdier. 'Trygt - farligt', 'stimulerende - kedelig', 'innovativ - traditionel' kunne være eksempler på mere abstrakte bipolare konstrukter.

Repertory grid er en metode til at afdække menneskers bipolare konstrukter og er blevet brugt en del i forbindelse med at opnå forbrugerforståelse (Epting et al., 1971; Sampson, 1972). Når man anvender det på forbrugeradfærdsproblemstillinger, går det kort sagt ud på, at man præsenterer en forbruger for forskellige sæt af tre produkter ad gangen. Et af de tre produkter bliver trukket frem, og forbrugeren bliver opfordret til at sige, hvordan dette produkt adskiller sig fra de to andre. Svaret kunne fx være, at dette produkt er smukt, mens de to andre er hæslige, hvorved det første bipolare konstrukt er fundet. Spørgsmålet gentages med de andre variationer af ' 1 ud af 3', og gentages så med nye sæt af 3 produkter. Almindeligvis bliver til sidst alle produkter ratet på alle fundne dimensioner; dette er dog ikke nødvendigt, hvis det kun handler om at finde de meningsdannende konstrukter.

Det er således en åben teknik, der kan give god indsigt i forbrugernes kriterier i forbindelse med opfattelsen af produkter inden for en bestemt kategori (Bech-Larsen \& Nielsen, 1999; Thomson \& McEwan, 1988). Metoden tager dog nødvendigvis udgangspunkt i eksisterende produkter, hvilket kan være begrænsende for de konstrukter, der kommer frem. Desuden fokuserer fremgangsmåden forbrugernes opmærksomhed på produkternes mere konkrete eller synlige egenskaber, og de mere abstrakte konstrukter - dem højere op i hierarkiet, hvor vi nærmer os de underliggende behov eller værdier - kommer ikke frem. 
En videreudvikling af repertory grid er Laddering, som prøver at råde bod på dette (Grunert \& Grunert, 1995; Reynolds \& Gutman, 1988). Laddering er en interviewteknik, der tager udgangspunkt i konkrete bipolare konstrukter, som fx er fremkommet gennem repertory grid. De danner dog kun udgangspunkt for selve dybdeinterviewet, som går ud på at generere de bagvedliggende, mere abstrakte konstrukter. Når man fx har genereret konstruktet 'smuk - hæslig' ved hjælp af at konfrontere forbrugeren med en række konkrete køkkenredskaber, så kan man spørge videre, om det er vigtigt for forbrugeren, at køkkenredskaber er smukke, og givetvis hvorfor det er vigtigt for forbrugeren, at de skal være smukke. På denne måde kan man eksempelvis generere det næste konstrukt 'afslappet - anstrengt', som dermed både er et konstrukt, der beskriver forskellige måder, hvorpå forbrugeren kan opfatte sig selv i køkkenet, og som siger, at for denne forbruger bidrager det smukke til at være mere afslappet. Man kan blive ved og måske generere som det tredje konstrukt ' $i$ harmoni med mig selv - ude af mig selv'. Dermed har man genereret en 'stige' (derfra begrebet laddering) 'smuk - føler mig afslappet - er i harmoni med mig selv', som siger noget om, hvorfor denne forbruger anser det for vigtigt, at køkkenredskaber er smukke. Der genereres en række sådanne stiger fra hvert interview, og der findes et instrument til at dokumentere de vigtigste stiger på tværs af en række interviews i et diagram, det såkaldte hierarkiske værdikort. Figur 4 viser et eksempel på et sådant hierarkisk værdikort, som er fra en ældre undersøgelse om danskernes forbrug af fisk og skaldyr, som indgik i forbrugerorienteret produktudvikling af fiskeprodukter.

Laddering kan tage udgangspunkt i repertory grid, men de konkrete konstrukter, der danner udgangspunkt for interviewet, kan også komme frem på andre måder. Laddering tager typisk stadigvæk udgangspunkt $\mathrm{i}$ konkrete eksisterende produkter, men bevæger sig derfra mod de abstrakte, ikke produkt-specifikke behov og værdier, og kan derfor være et godt udgangspunkt for forbrugerorienteret produktudvikling. Det, man så typisk gør, er at man tager udgangspunkt i de mere abstrakte behov og værdier, som man tager for givet, og opfatter produktudviklingsopgaven som et forsøg på at konstruere produkter med konkrete egenskaber som forbrugerne vil kunne knytte til deres behov og værdier. Eksemplet i figur 4 viser, at forbrugernes overordnede mål og værdier i forbindelse med køb af frisk fisk kunne opfyldes bedst ved at tage udgangspunkt i de opfattede (negative) egenskaber omkring manglende tilgængelighed og besvær med tilberedningen, hvilket gav anledning til en række nye produkter og distributionsmåder. 


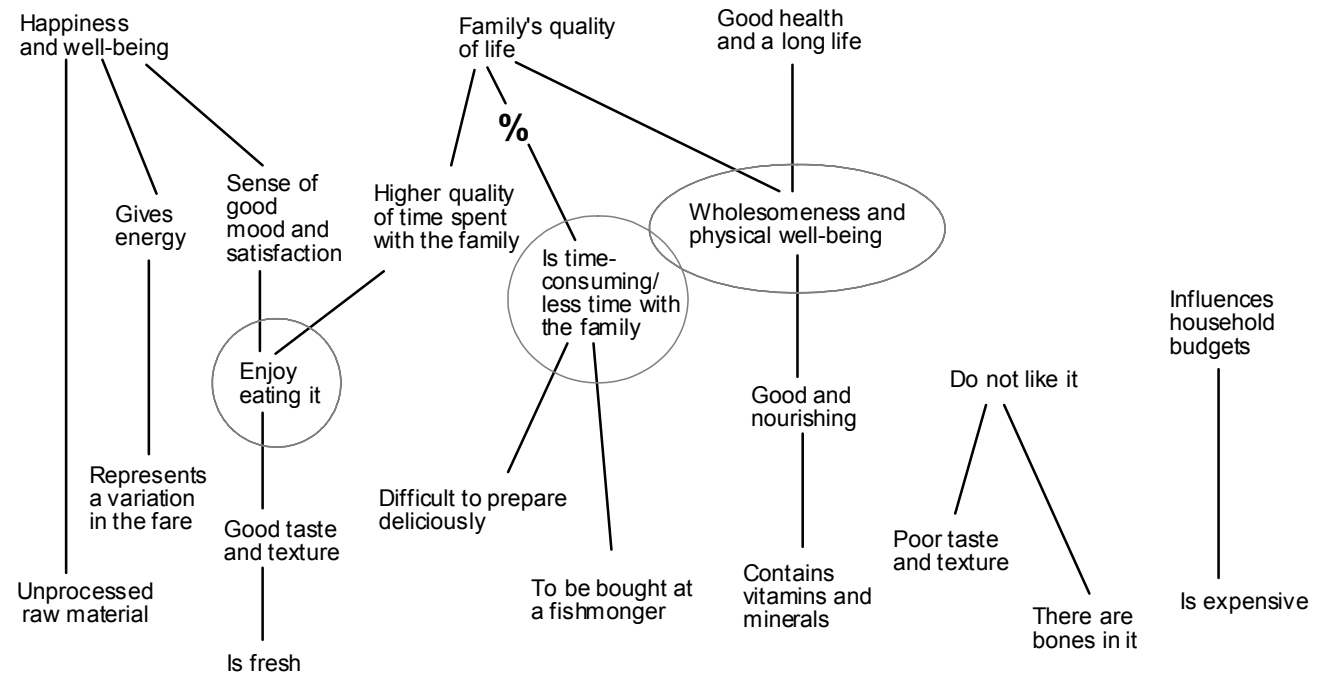

Figur 4: Hierarkisk vardikort for frisk fisk

Adapteret fra Nielsen et al., 1997

Nutana-casen i næste afsnit er et andet eksempel på denne fremgangsmåde. Laddering bliver brugt ganske meget i både produkt- og kommunikationsudviklingen, selv om metoden er slåt lidt mindre igennem i de nordiske lande end i de store EU lande eller i USA. Der findes også lignende tilgange, der går under andre navne (se fx Nielsen et al., 1997).

Laddering metoden sigter direkte mod den vertikale dimension i Forbrugerkvalitetsmodellen og tillader direkte indsigt i, hvordan forbrugernes mål, kvalitetsopfattelse og opfattede produktegenskaber hænger sammen. Metoden med at føre forbrugeren fra konkrete produkter mod abstrakte mål sætter produkterne ind i en større sammenhæng, der kan give inspiration også til nye produkter med en høj innovationsgrad. Metoden er i sin grundform kvalitativ, og indsigt vundet derigennem skal almindeligvis valideres gennem mere repræsentative undersøgelser.

\section{Zaltman Metaphor Elicitation Technique}

Zaltman Metaphor Elicitation Technique (ZMET) (Christensen \& Olsen, 2002; Zaltman, 1997; Zaltman \& Higie, 1993) bygger videre på grundtankerne i repertory grid og laddering, men udvider dem hovedsageligt på to måder. For det første bliver det betragtet som en ulempe, at man i disse metoder kun arbejder verbalt, mens en stor del af forbrugernes måde at tænke på foregår i billeder. For det andet bliver metaforen introduceret som et centralt analyseredskab. Det er en grundantagelse i ZMET, at tænkningen foregår i metaforer, dvs. at man prøver at forstå noget ved at analysere det i termer inden for noget andet. Grundtanken i ZMET er derfor at fremkalde de metaforer, som en forbruger anvender i forbindelse med en produktkategori, og at gøre det på en måde, som tager hensyn til det ikke-verbale. Det foregår i praksis sådan, at forbrugere får oplyst den 
produktkategori, det emne, eller det mærke, der skal arbejdes med, og bliver instrueret til at samle billeder om emnet - enten ved selv at tage billeder med et kamera, eller ved at samle billeder fra blade, aviser m.m. Forbrugeren får ca. en uge til det, og bliver så indkaldt til et opfølgende dybdeinterview. Interviewet indeholder en række forskellige trin, men hovedessensen er, at forbrugeren skal fortælle de historier, der knytter billederne til produktkategorien (eller det emne som undersøgelsen nu handler om), og der bliver brugt en række teknikker (herunder også laddering) til at skabe forbindelser mellem de forskellige historier, metaforer og konstrukter, som forbrugeren kommer med. Også her er der til sidst et trin, hvor man prøver at fange de vigtigste begreber, der er kommet frem på tværs af en række forbrugere. Figur 5 viser et eksempel fra en amerikansk undersøgelse om kvindeundertøj.

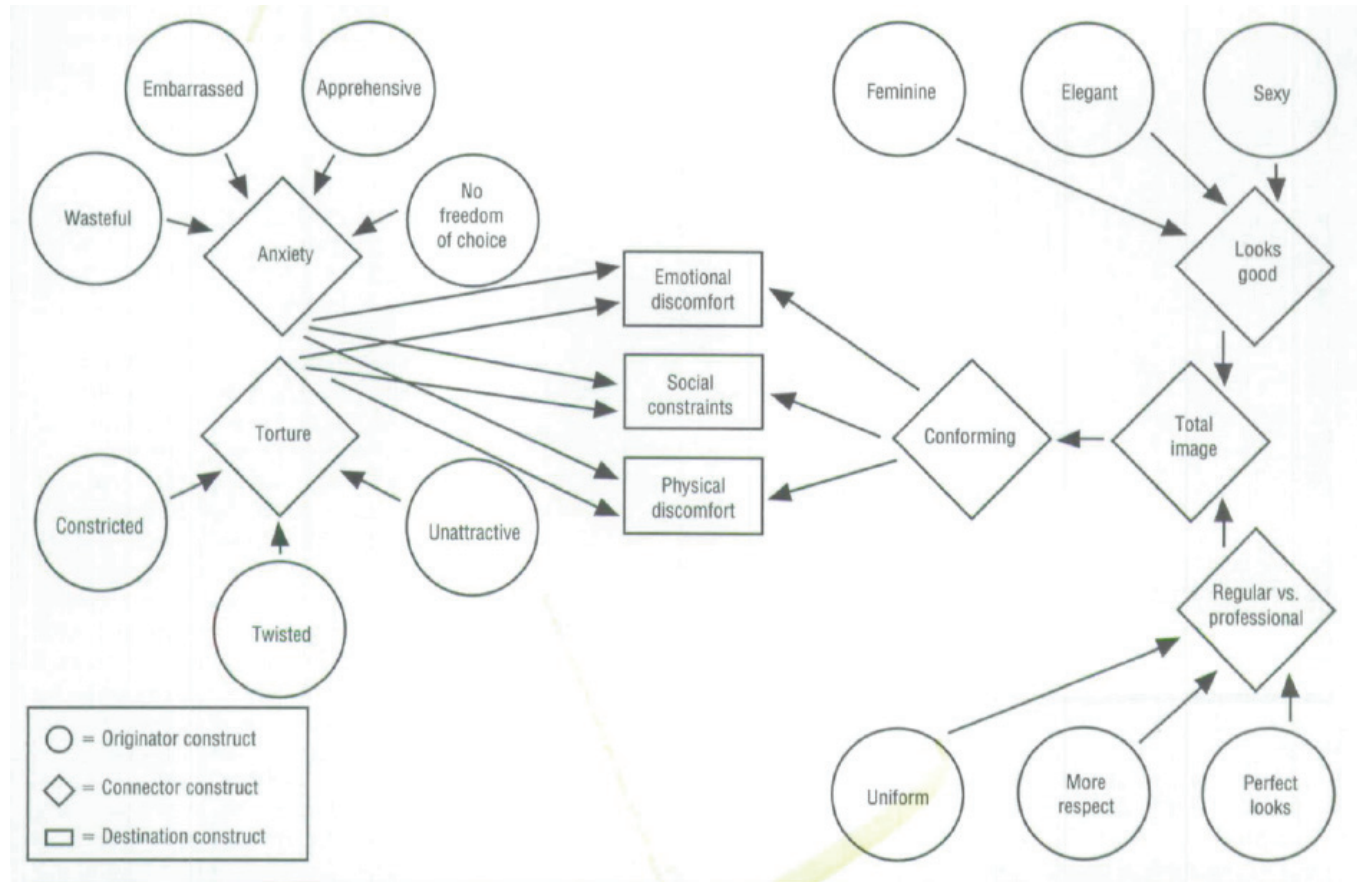

Figur 5: Mental map for kvindeundertøj

Kilde: Zaltman \& Coulter, 1995

Der medfølger ingen umiddelbare anvisninger på, hvordan man kan nyttiggøre oplysningerne i produktudviklingen, og de fleste anvendelser af metoden har da også været i kommunikations- frem for produktudviklingen (Coulter et al., 2001). Men metoden giver masser af inspiration og indsigt $\mathrm{i}$ forbrugernes tænkemåder, og vægten på det billedlige og metaforiske er en interessant tilgang. Metoden er dog kompliceret og dyr, og der findes - så vidt vi ved - ingen anvendelser på det nordiske område endnu. 
Gruppe 2: Indsigt i udviklinger af sammenhoengen mellem mål, kvalitetsopfattelse og produktegenskaber

Vi diskuterer her to redskaber, der kan supplere dem i gruppe 1 ved at de tilføjes et dynamisk perspektiv, hvor man ser på forbrugertrends, der kan påvirke, hvordan de kæder mål sammen med kvalitet og produktets egenskaber.

\section{Scenariemetoden}

Scenariemetoden er ikke nogen egentlig metode til forbrugerforståelse. Begrebet dækker over en række værktøjer, der skal disciplinere et individs måder at tænke over fremtiden på, så at fremtidsforståelsen ikke kun er ren intuition eller gætværk, men fremkommer på en mere struktureret måde. Scenariemetoden kan derfor også anvendes til at spå om fremtidige forbrugerbehov og vil i så fald typisk blive fodret af oplysninger, som er kommet frem gennem nogle af de ovenfor omtalte metoder, ligesom nogle af dem, der bliver beskrevet i de næste afsnit, kan bidrage med input.

Scenariemetoden kategoriseres ofte som "disciplineret intuition" (Wright \& Ayton, 1987). Den er intuitiv ud fra den betragtning, at den fremkalder kreativ fremtidstænkning. Omvendt er den disciplineret, som følge af at det er en systematiseret og styret proces. Et scenarie kan ses som et middel til at forudse, hvor fremtiden kunne være på vej hen, således at man i tide kan justere sine handlinger (P. Schwartz, 1991). Målet med scenarier er dog ikke at forudsige fremtiden, men derimod at udvikle alternative syn på mulige fremtidsbilleder. Det er i højere grad fremtidens struktur end de eksakte detaljer, som er af interesse. I modsætning til almindelig forecasting fremskriver scenarier desuden ikke kun de nuværende trends, men udfordrer vanetænkningen ved tillige at fremkomme med alternative fremtidsbilleder. Scenariemetoden udmønter sig derfor som oftest i 2-4 scenarier, som alle skal have følgende egenskaber (Fahey \& Randall, 1998; Godet \& Roubelat, 1996; Heijden, 1996):

- De skal være plausible, hvilket vil sige, at de skal kunne realiseres med større eller mindre sandsynlighed, bare sandsynligheden ikke er nul.

- De skal være internt konsistente. Udfaldet af de faktorer, som scenariet består af, må ikke være i modstrid med hinanden. Det er eksempelvis svært at forestille sig en situation, hvor høj inflation og lav rente forekommer på samme tid.

- Scenarierne skal være relevante for det område, der ønskes undersøgt. Der skal være sammenhæng mellem nutid og fremtid, dvs. der skal være en ubrudt linie mellem de to situationer.

- De skal udfordre vanetænkning.

Scenarierne konstrueres omkring prædeterminerede faktorer og - først og fremmest - nogle få centrale drivkræfter. Prcedeterminerede faktorer er 
trends, hvis fremtidige udvikling er forbundet med meget lille usikkerhed (for eksempel at der bliver flere ældre). Disse faktorer skal behandles i hvert enkelt scenarium i en eller anden form, såfremt de er vigtige for fokusområdet. Drivkrcefter udgøres derimod af de faktorer, der knytter sig størst usikkerhed til, og som samtidig har den største betydning for den fremtidige udvikling inden for fokusområdet, hvorved de kan drive udviklingen i forskellige retninger. Vigtige prædeterminerede faktorer og centrale drivkræfter udgør til sammen "scenarieskelettet". Dette skelet påfyldes dernæst forskellige udfald for de øvrige vigtige og usikre faktorer på en sådan måde, at det hænger logisk og konsekvent sammen med grundstrukturen (Schwartz, 1991).

Scenariemetoden kan være et vigtigt komplement til de andre teknikker, hvis det er målet at fremkomme med langsigtede perspektiver i innovationsprocessen. I forhold til Forbrugerkvalitetsmodellen kan den inddrage aspekter, der medfører udviklinger i de mål, forbrugere har med produkterne, og de situationer, de anvender dem i.

\section{Lead user metoden}

Lead user metoden, som går tilbage til innovationsforskeren von Hippel (Urban \& von Hippel, 1988; von Hippel, 1986), tager udgangspunkt i den kendsgerning, at der findes tilfælde, hvor det faktisk er brugerne, ikke producenterne, som er innovative. Fænomenet er blevet observeret mest på industrielle markeder, dvs. markeder hvor brugerne ikke er forbrugere, men professionelle aftagere. Fx på markeder for videnskabelige instrumenter, elektroniske komponenter og it-produkter er det dokumenteret, at visse brugergrupper nogle gange kan stå for størstedelen af innovationerne, som producenterne så bare overtager og kommercialiserer. Tre betingelser skal være opfyldte, før en bruger bliver til en sådan lead user: a) brugeren skal have nogle meget specifikke behov, som de på markedet eksisterende produkter ikke opfylder, b) brugeren skal have evnen til selv at kunne modificere de eksisterende produkter, så at de modsvarer behovene (hvilket for det meste betyder, at der er grænser for produkternes teknologiske sofistikering), $\mathrm{og} \mathrm{c}$ ) den nytte, som brugeren personligt får ud af at være innovativ, er så stor, at den motiverer brugeren til at bruge tid og kræfter på at være innovativ, selv om det kan betyde, at innovationen i sidste ende også kommer andre til gode, og andre kan komme til at tjene penge på den.

Mens lead user fænomenet er rimelig veldokumenteret på industrielle markeder (Herstatt \& von Hippel, 1992; Lilien et al., 2002), er fænomenet på konsumentvaremarkeder mere sparsomt belyst. Der findes dog en række anekdoter og mindst én større undersøgelse, som viser, at der fx findes en del lead user-agtige forbrugere, når det handler om udstyr til udendørssportsaktiviteter som klatring, langrend skiløb og mountain biking (Franke \& Shah, 2003). En tysk undersøgelse inden for disse produktkategorier viste, at cirka en tredjedel af forbrugerne på dette marked i 
det mindste havde idéer til produktforbedringer eller nye produkter, og at $15 \%$ rent faktisk havde kontaktet producenten med henblik på at få gennemført produktmodifikationer, selv om dette kun i $3 \%$ førte til et egentligt samarbejde (Lüthje, 2003).

Lead user metoden er et forsøg på at udnytte eksistensen af disse særlige brugertyper i en innovationsproces. I sin oprindelige form (von Hippel, 1986) omfatter metoden fire trin:

1. Først skal der identificeres de markedstrends, der skal tages udgangspunkt i. En lead user er en person, der er foran de andre brugere på et bestemt felt; de specifikke behov, som lead useren har, og som fører til hans innovationstrang, vil senere blive mere udbredt på hele markedet for produktkategorien. Der kan dog være mange trends, der gør sig gældende på et bestemt marked, og identificeringen af den eller de trends, man ønsker at arbejde med, skal derfor foretages af den pågældende virksomhed og skal styre det næste trin, hvor der skal identificeres brugere, der er foran med henblik på den valgte trend. Den ovenfor omtalte scenarieteknik kan være nyttig til at identificere relevante trends. For eksempel kunne convenience være en trend inden for fødevarekategorien.

2. Når trenden er valgt, skal der findes brugere, der er foran hvad denne trend angår, og som forventes at få specielt meget udbytte af innovation, der tager udgangspunkt i trenden. På konsumentvaremarkeder kan dette nemmest gennemføres gennem et survey, som i eksemplet kortlægger madlavningsvaner og brug af convenience produkter. Specielt interessant er her forbrugere, som har taget sagen i egen hånd og lavet deres egne løsninger, fx ved at forhåndsproducere måltidskomponenter selv og fryse dem ned. Analoge industrielle brugere, i eksemplet kunne det være brugere fra storkøkkener, kan muligvis også inddrages.

3. I tredje trin skal lead userne nyttiggøres til udviklingen af innovative produktkoncepter. Dette kan gøres på mange forskellige former; på industrielle markeder kan det betyde at en gruppe lead users inviteres til en workshop sammen med ingeniører og produktudviklere fra producenten med det formål at udvikle innovative produktkoncepter (se fx Herstatt \& von Hippel, 1992). Dette er principielt også muligt på konsumentvaremarkeder, men man kan også nøjes med at gennemføre nogle af de mere klassiske dialogteknikker med disse folk, som fx en fokusgruppe eller en række dybdeinterview.

4. Endeligt anbefales det at teste de nyvundne produktkoncepter over for en mere almindelig brugergruppe, hvilket kan ske ved hjælp af klassiske markedsanalyseteknikker.

Hovedbudskabet fra lead user tilgangen er, at man skal opgive repræsentativitetstankegangen, når det handler om at skaffe brugerinput i en inno- 
vationsproces. I de klassiske markedsanalyseteknikker opfatter man repræsentativitet som et kvalitetskriterium - det survey eller den undersøgelse, man gennemfører, skal være repræsentativ for hele markedet. De fleste nuværende kunder er dog begrænset i deres tænkemåde af de eksisterende produkter, og er dermed ikke særlig innovative. Det handler derfor om at identificere de brugere, der allerede har tænkt længere end de andre, og arbejde med dem, i stedet for med en gruppe brugere, der er repræsentative for hele markedet.

Metoden er som sagt ikke blevet brugt særlig meget inden for konsumentvaremarkeder, men nogle af de teknikker, der omtales under overskriften brugerorienteret eller empatisk design (omtalt nedenunder), har et vist intellektuelt fællesskab med lead user metoden. Vi beskriver i næste afsnit en case fra et industrielt marked som illustration på anvendelsen af metoden.

Ligesom scenariemetoden kan lead user metoden, i forhold til Forbrugerkvalitetsmodellen, mest rette opmærksomheden mod nye mål og nye anvendelser af et produkt, som visse (for)brugergrupper er forud med i forhold til det samlede marked, og det kan give indsigt $i$, hvad disse nye mål og anvendelser kommer til at betyde for kvalitetsbegrebet og for produktets ønskede egenskaber.

\section{Gruppe 3: Kvantitative analyser af hvilke parametre der påvirker kvalitets-opfattelsen}

De op til nu omtalte redskaber er alle kvalitative og kontekstorienterede. De tillader dyb indsigt $i$, hvordan et fătal af udvalgte forbrugere tænker om en produktkategori og dens betydning i deres liv. Desuden bygger de alle på refleksion - oplysningerne fremkommer ved, at man opmuntrer forbrugerne til at tænke lidt mere, reflektere over tingene, se på tingene fra forskellige vinkler og beskrive den rolle, produkterne spiller i deres liv.

Den gruppe redskaber, som vi nu kommer til, har derimod en helt anden tilgang. De sigter mod at analysere, hvilke faktorer der har mest indflydelse på forbrugernes kvalitetsopfattelse, og har dermed fra starten et mere reduktionistisk sigte. De sigter mod en kvantificering af resultaterne. De kan anvendes på større stikprøver af forbrugere og kan dermed opfylde et ønske om repræsentativitet, der hvor det ønskes. Endeligt bliver hovedresultaterne ikke direkte afledt af forbrugernes svar i undersøgelsen, men af en statistisk bearbejdning af de indsamlede data.

Det sidste er ikke kun en teknisk forskel, men rører ved et afgørende spørgsmål, når det handler om analyse af forbrugeradfærd, nemlig om forbrugerne er i stand til selv bevidst at erkende de faktorer, der styrer deres adfærd. Alle teknikker i grupperne 1 og 2 bygger mere eller mindre eksplicit på denne antagelse, selv om nogle af dem - især laddering og ZMET - gør meget ud af at opmuntre forbrugerne til at tænke på nye 
måder. Teknikkerne i gruppe 3 bygger derimod på en antagelse om, at væsentlige drivkræfter af forbrugeradfærden kan analyseres ved statistisk analyse, uanset om forbrugeren selv har bevidsthed om dem. Forbrugerne afkræves i disse teknikker kun svar på ret enkle, og på forhånd formulerede spørgsmål med forud givne svarmuligheder.

\section{Category appraisal}

Denne gruppe redskaber, som tit også kaldes for perceptual mapping, har et enkelt formål: Man ønsker at visualisere den måde, forbrugerne opfatter en bestemt produktgruppe på, ved at placere de forskellige eksisterende produkter i produktgruppen i et 'rum' - almindeligvis et to- eller tredimensionelt rum, fordi ellers bliver tolkningen noget vanskelig. Produkter, der ligger tæt ved hinanden i rummet, ligner hinanden i forbrugernes opfattelse, mens produkter, der ligger langt fra hinanden, opfattes som meget forskellige. De dimensioner, der definerer rummet, er samtidig de afgørende faktorer, der driver forbrugernes opfattelse af produkterne inden for kategorien (Carroll \& Green, 1997; Green \& Rao, 1972).

Figur 6 (fra Hauser \& Wisniewski, 1979) viser et enkelt eksempel. Produktgruppen er transportydelser, og de enkelte produkter er at gå, at cykle, at tage bussen og at tage bilen. Det viser sig, at transportydelsernes opfattelse kan forklares gennem tre dimensioner:

- hurtighed og effektivitet: at kunne komme frem uden ventetid, til tiden og hurtigt

- bekvemmelighed: uden fysisk anstrengelse, ikke trættende, ingen problemer ved dårligt vejr, let at bruge med bagage eller med børn

- behagelighed: afslappende, uden forstyrrelser, trygt

I forbindelse med forbrugerorienteret innovation opnår man gennem en sådan analyse to typer information. For det første opnår man en forståelse af de kernedimensioner, der driver forbrugernes kvalitetsopfattelse i produktkategorien, hvilket kan give værdifuld inspiration til udvikling af nye produkter, som forbrugerne vil danne præference for. For det andet kan der opdages 'huller' i det eksisterende udbud - dele af rummet, hvor der p.t. ikke findes produkter, men hvor et nyt produkt kunne placeres og måske blive til en succes. 


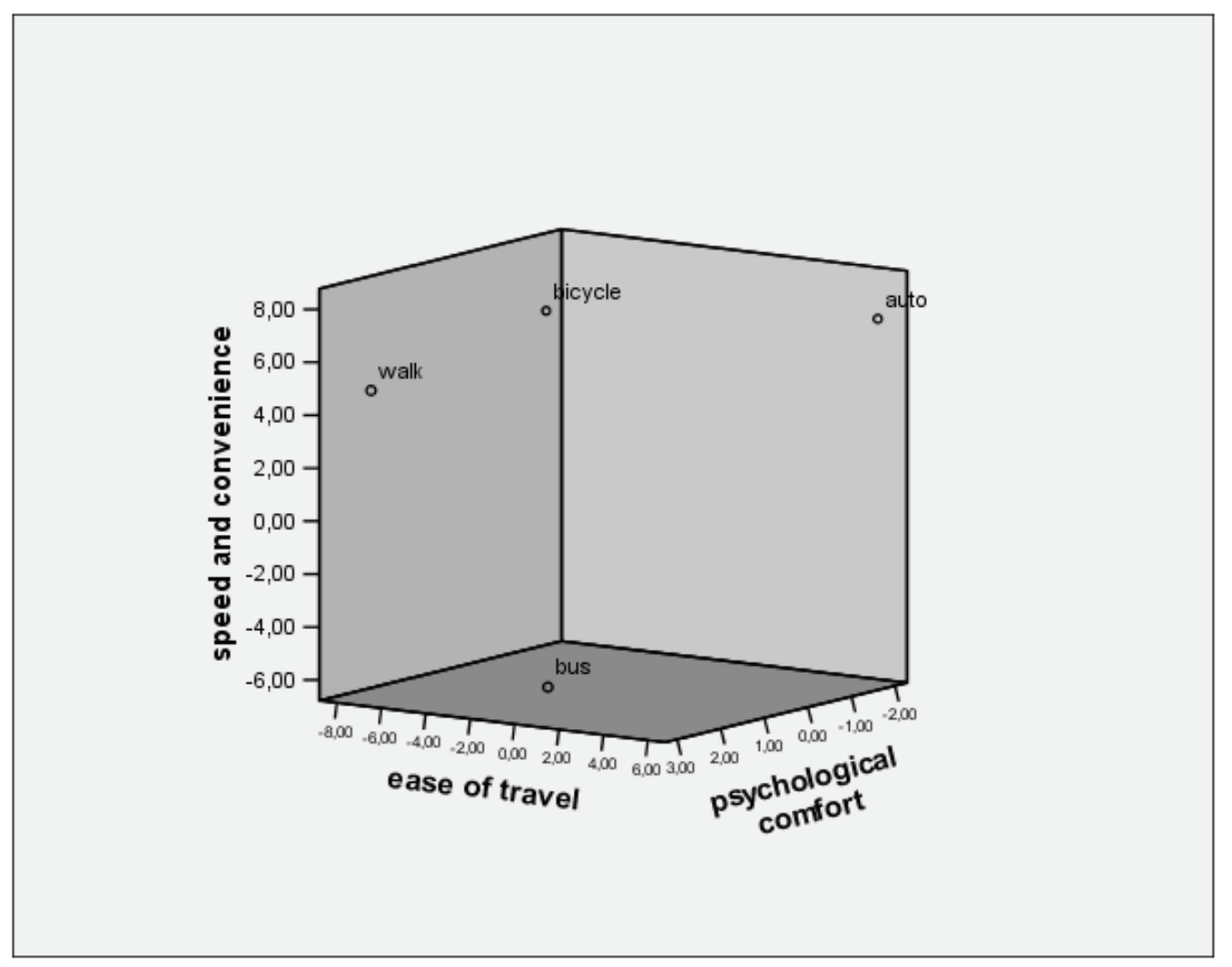

Figur 6: Nøgledimensioner i opfattelsen af transportydelser

Kilde: Hauser \& Wisniewski, 1979

Der findes forskellige metoder til at komme frem til et sådant produktrum. De har alle til fælles, at en stikprøve af forbrugere skal tage stilling til de eksisterende produkter, der skal placeres i rummet. Metoderne adskiller sig så $i$, hvilken type data der skal indsamles om disse produkter. De tre alternative hovedtilgange er: a) indsamling af præferencedata, hvor forbrugerne bedømmer produkterne gennem en rangordning eller en vurdering på en præferenceskala, b) indsamling af data, hvor hvert produkt bedømmes ud fra en række produktegenskaber, og c) indsamling af data, hvor forbrugerne skal tage stilling til, hvor meget produkterne - parvist - ligner hinanden. Der findes forskellige statistiske metoder (de vigtigste er den såkaldte hovedkomponentanalyse og flerdimensional skalering) der kan bruges for at udlede de perceptuelle rum ud fra dataene.

Metoderne er konservative i den forstand, at de bygger på data, der er knyttet til det eksisterende udbud af produkter. Man kan forestille sig, at et virkelig innovativt produkt, der tager helt andre forbrugerbehov op, vil bryde det perceptuelle rum og skabe nye dimensioner. I eksemplet om transportydelser kunne man $\mathrm{fx}$ forestille sig, at 'oplevelser under transporten' kunne være en ny innovativ dimension, der kunne føre tankerne 
hen mod helt andre serviceydelser, end dem vi kender i dag. Men hvis vi ser bort fra de radikale innovationer, er category appraisal en god måde at skabe indsigt $i$, hvordan forbrugerne opfatter kvalitet i en produktkategori.

I forhold til Forbrugerkvalitetsmodellen kan metoderne mest bruges til at belyse den midterste del, dvs. at afdække de hovedkvalitetsdimensioner, som udgør forbrugernes kvalitetsopfattelse.

\section{Conjoint analyse}

Grundidéen er her den samme, nemlig af finde og kvantificere de dimensioner, der påvirker forbrugernes kvalitetsopfattelse i en produktkategori. Forskellen er, at man her er interesseret i effekten af konkrete, på forhånd specificerede produktegenskaber. Fremgangsmåden er, at man beder forbrugere om at vurdere attraktiviteten af en række hypotetiske nye produkter, som kan være beskrevet verbalt og/eller ved hjælp af billeder. Disse hypotetiske produkter bliver konstrueret ud fra et såkaldt faktorielt design, hvor man systematisk krydser de forskellige udfald af en række produktegenskaber. Gennem statistiske metoder kan man ud fra forbrugernes vurderinger bagefter estimere, hvilke egenskaber bidrager hvor meget til den samlede præference, og hvilke udfald af de forskellige egenskaber forbrugerne havde mest præference for. Resultaterne tillader dermed, inden for sættet af de på forhånd definerede egenskaber og deres udfald, at konstruere det 'ideale' produkt - det produkt, som de forbrugere, produktet sigter imod, bedst vil kunne lide (Carroll \& Green, 1995; Green et al., 2001; Moore et al., 1999).

Metoden er meget brugt i innovationsøjemed (Lilien \& Rangaswamy, 1998), og der findes et hav af forskellige varianter, som stort set alle er forsøg på at komme det problem til livs, at et produkt tit består af ganske mange relevante produktegenskaber, men at det er hverken muligt at gøre produktbeskrivelserne alt for komplekse for forbrugeren, eller at udsætte dem for alt for mange af disse produktbeskrivelser. Kompleksiteten af dataindsamlingen skal begrænses, samtidigt med at realismen opretholdes. Et godt eksempel på dette er Marriott Courtyard casen i næste afsnit.

Metoden belyser, hvordan et sæt afgrænsede produktegenskaber påvirker den samlede kvalitetsopfattelse af et produkt. Den kræver en del forhåndsviden, fordi resultaterne aldrig bliver åbenlyst bedre end de produktegenskaber, man på forhånd har defineret. Metoden vil derfor aldrig kunne stå alene $\mathrm{i}$ en innovationsproces. Men når problemet er blevet struktureret så meget, at man har en bruttoliste af potentielt relevante produktegenskaber, så er metoden yderst nyttigt til at optimere nye produkter på en forbrugerorienteret måde. 


\section{Gruppe 4: Indsigt i produkternes anvendelse}

Et af hovedbudskaberne i Forbrugerkvalitetsmodellen var, at forbrugernes kvalitetsopfattelse ikke kun styres af selve produktet, men i høj grad også af hvordan produktet anvendes. Dybere indsigt i, hvordan produkterne anvendes hos forbrugerne, kan derfor være en vigtig kilde til inspiration i forbrugerorienteret innovation.

Mens indsigt i forbrugernes anvendelse af produkterne kan opnås gennem mange metoder, herunder gennem fokusgrupper eller dybdeinterviews hvor forbrugerne beretter om anvendelsen og oplevelserne knyttet hertil, så er det nærliggende, at produkternes anvendelse er noget, der burde kunne studeres lettest gennem observation af forbrugerne i de naturlige omgivelser, hvor produkterne faktisk bliver brugt. Denne tilgang til brugeranalyse er i innovationssammenhæng mest blevet diskuteret under navnet empatisk design (Leonard, 1995; Leonard \& Rayport, 2000), men der findes også andre betegnelser, som fx contextual inquiry (Beyer \& Holtzblatt, 1998). Proponenter af empatisk design går endda et skridt videre og hævder, at observation af brugere i deres naturlige omgivelser ligefrem er kongevejen til brugerorienteret innovation. Begrundelsen er, at man dermed kan frigøre sig af de bånd, som brugernes egne erfaringer og det dermed forbundne sprogbrug udgør i alle de metoder, der er baseret på verbale beretninger fra (for-)brugerne. Observation tillader indsigt $i$ aspekter, som brugerne ikke selv er bevidste om, og som de derfor ikke ville ytre i fx et interview, men som alligevel kan give vigtig inspiration til nye eller forbedrede produkter. Det gælder fx indsigt $i$, hvilke situationer der i det hele taget udløser ønsket om at bruge produktet, interaktion mellem brugssituation og brugsmåder, samt produktanvendelser som producenten aldrig havde til hensigt (et eksempel i litteraturen er fx en forbruger, der brugte en madoliespray til at behandle sin plæneklipper).

Det at man prøver at undgå sproget som kommunikationskanal (det er dog tilladt at stille fx spørgsmål som 'hvorfor gør du det her') er både en styrke og en svaghed. Man undgår som sagt de begrænsninger, der følger af forbrugernes sprogbrug, men samtidig er det klart, at den observerede adfærd kræver tolkning, mange gange endda ganske meget tolkning, før den bliver til information, der kan bruges i en innovationsproces. Metoden er mere beskrivende end forklarende; til gengæld er den i høj grad kontekstorienteret, og konteksten skal underbygge tolkningen af det observerede. Det er derfor vigtigt at sikre, at en mangfoldig tolkning bliver muliggjort. Dokumentation af observationen gennem video er et vigtigt instrument, der sikrer, at tolkningerne kan gentages og valideres. Et andet instrument er brug af forskellige observatører med forskellig faglig baggrund. Ingeniører og psykologer vil se helt forskellige aspekter i den samme adfærd; mens den første måske straks tænker i nye produktløsninger, vil den anden i første omgang sigte mod at forstå den observerede adfærds drivkræfter. Det anbefales også, at man i den videre tolkning 
også inddrager personer, som ikke deltog i selve observationen, for at få en yderligere udvidelse af tolkningsspektret. Derfra kan man tage den kreative proces videre gennem brainstorming for nye løsninger.

Idéerne omkring empatisk design er et vigtigt komplement til de mere verbale redskaber. Ligesom et laddering interview lægger de fokus på, hvad produkterne gør for forbrugeren mere end hvad de er, men i modsætning til laddering interviews får situationsbestemte aspekter og interaktionen mellem produkt og bruger meget mere vægt. Det er dog også en dyr og tidskrævende metode, og anvendes den i stor stil, genererer den store mængder af data, som det kan være besværligt at reducere til nogle få innovationsorienterede idéer.

\section{Gruppe 5: Indsigt i indfrielse af forventninger og forbrugertilfredshed}

Hvis den kvalitet, forbrugeren oplever, indfrier eller overgår forventningerne, så bliver forbrugeren tilfreds. En forbruger, der er tilfreds, bliver loyal over for producenten. Loyale kunder er producentens fremtid (Oliver, 1997).

Ovenstående er kernen af filosofien bag en række instrumenter, der sigter mod at måle og forklare forbrugernes tilfredshed og loyalitet. Der har været både virksomhedsorienterede og samfundsorienterede drivkræfter bag udviklingen af disse instrumenter. Samfundet er interesseret $i$ at markederne fungerer, og hvad kunne dokumentere dette bedre, end hvis forbrugerne på markederne er tilfredse med de produkter og ydelser, de får? $\mathrm{Og}$ virksomhederne er interesserede i tilfredse og loyale kunder, i den udstrækning at det sikrer virksomhedens fremtid og vækst. Loyale kunder er en vigtig ressource for virksomheden, fordi det for det meste er meget mindre ressourcekrævende at holde på de kunder, man har, end at finde nye. Kundetilfredshed og -loyalitet er derfor blevet lanceret som virkomhedspræstationsmål på linje med markedsandel og profitabilitet, og det er især blevet fremhævet, at disse mål er fremtidsorienterede - de siger noget om virksomhedens grundlag for at kunne drive forretning fremover, mens markedsandel og især profitabilitet er bagudrettede mål, som mest siger noget om, hvor godt virksomheden har gjort det i perioden op til nu.

De instrumenter, vi taler om her, er standardiserede, kvantitative og reduktionistiske. De sigter mod at måle og forklare tilfredshed og loyalitet på en sådan måde, at målingerne bliver sammenlignelige over tid, mellem virksomheder og også mellem markeder og industrier. Det sidste er en forudsætning, hvis resultaterne skal kunne bruges til at bedømme, hvilke markeder der fungerer bedre end andre. Det første er en forudsætning, hvis den enkelte virksomhed skal kunne vurdere sin evne til at skabe tilfredshed og loyalitet i forhold til konkurrerende virksomheder, og hvis den vil overvåge udviklingen af denne evne over tid. 
Sverige var det første land, hvor en sådan målemodel blev iværksat (Fornell, 1992). Den blev senere, i let modificeret form, overtaget i USA (Fornell et al., 1996), for så senere at vende tilbage til Europa i form af European Customer Satisfaction Index (ECSI), som er et standardiseret instrument, der anvendes i en række europæiske lande og bliver koordineret af et paneuropæisk udvalg (Juhl et al., 2002; Kristensen et al., 2000). ECSI grundmodellen er vist i figur 7.

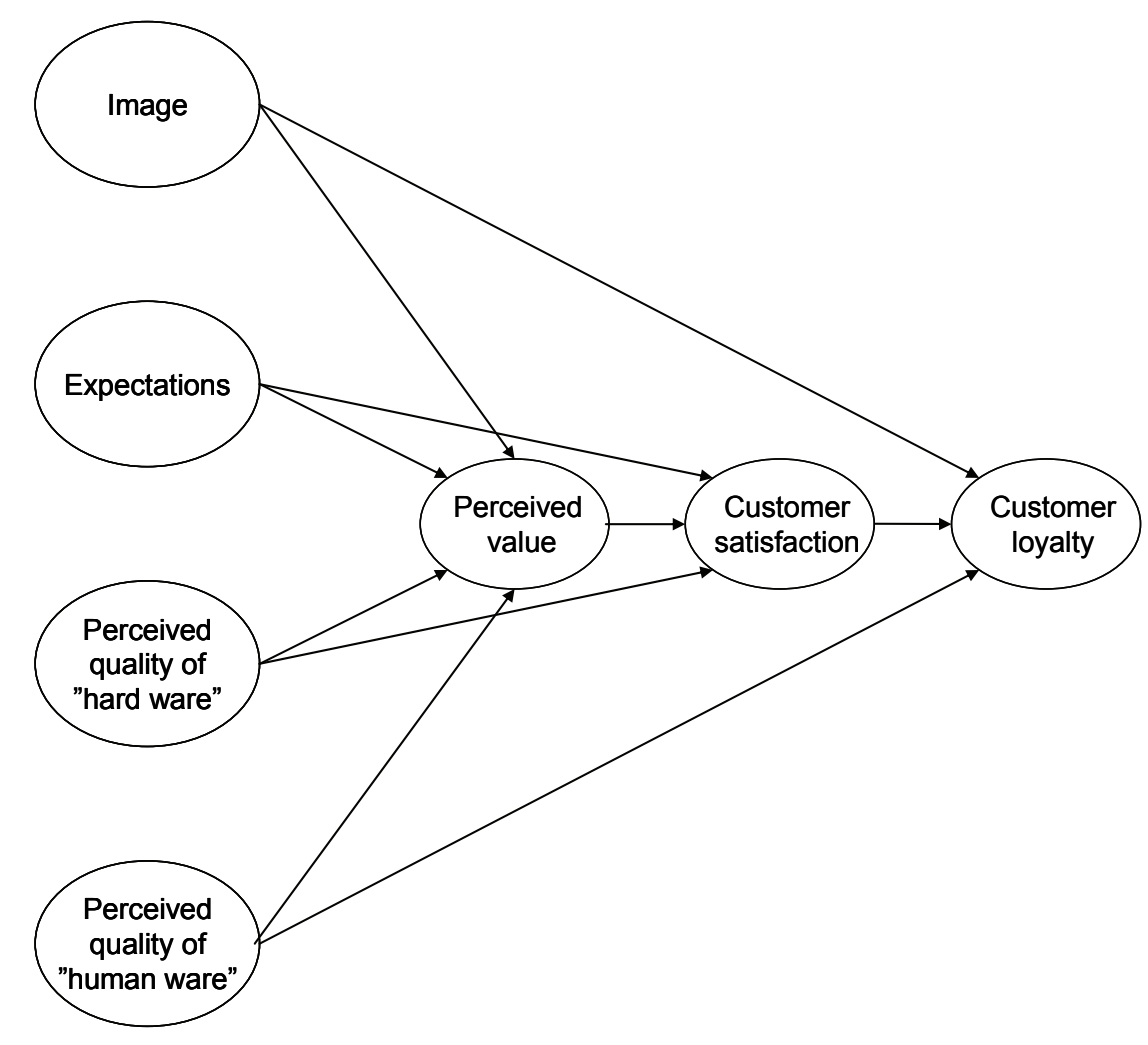

Figur 7: ECSI modellen

Modellen tager højde for en række komplikationer i forhold til den grundlæggende, enkle filosofi refereret i begyndelsen af afsnittet. Det er ikke kun diskrepansen mellem forventningerne og oplevelsen, der afgør tilfredshed - og det er desuden heller ikke kun tilfredsheden, der afgør loyalitet. Forventningerne kan direkte påvirke tilfredsheden, især i de tilfælde, hvor forbrugeren har svært ved at bedømme, om en forventet kvalitet faktisk er til stede (de tidligere omtalte 'troskvaliteter'). Niveauet af den oplevede kvalitet kan direkte påvirke tilfredshed, uanset hvad forventningerne var. Nogle af de mere 'bløde' faktorer knyttet til oplevelsen af et produkt eller en serviceydelse kan påvirke loyaliteten direkte.

Variablene i ECSI måles via et standardiseret spørgeskemainstrument. Resultaterne gengives i scores, som tillader de ovenfor omtalte sammenligninger. Modellen har desuden den fordel, at den tillader en vurdering 
af den såkaldte interne validitet - dvs. man kan checke, om det nu også lykkes at forklare udsvingene i tilfredshed og loyalitet.

I forhold til forbrugerorienteret innovation har virksomheder, der bruger ECSI, mulighed for at forfølge udviklingen i forbrugernes tilfredshed over tid eller i forhold til konkurrenterne, og får dermed oplysninger om potentiale for forbedringen af tilfredsheden. Idet tilfredshed desuden bliver forklaret gennem oplevet kvalitet, forventninger og image, får virksomheden også en række overordnede fingerpeg om, hvordan tilfredsheden kan forbedres. Den store vægt på sammenlignelighed og standardisering medfører dog også, at ECSI standardmodellen skal suppleres med andre analyser, hvis virksomheden skal få mere konkret indsigt i, på hvilke områder de skal satse for at kunne øge forbrugertilfredshed gennem modificerede eller nye produkter.

Der findes også andre kvantitative instrumenter til måling af indfrielse af forventninger, tilfredshed og loyalitet, der bygger på en lignende grundfilosofi, men som vægter standardiseringen, og dermed sammenligneligheden, på tværs af markeder noget mindre for til gengæld at kunne indarbejde markeds- eller virksomhedsspecifikke determinanter af tilfredshed og loyalitet. Et eksempel herpå er RelationScore, som forklarer forbrugertilfredshed og -loyalitet gennem de 'bånd', virksomheden formår at knytte til forbrugeren, hvor hvert bånd igen forklares af en række 'drivers'. Der skelnes mellem fire typer af 'bånd': funktionelle, formmæssige, finansielle og følelsesmæssige. 'Drivers' er markeds- eller virksomhedsspecifikke og dækker alle de kvalitetsdimensioner, som er blevet identificeret som relevante gennem fx fokusgrupper. RelationScore modellen er vist i figur 8 .

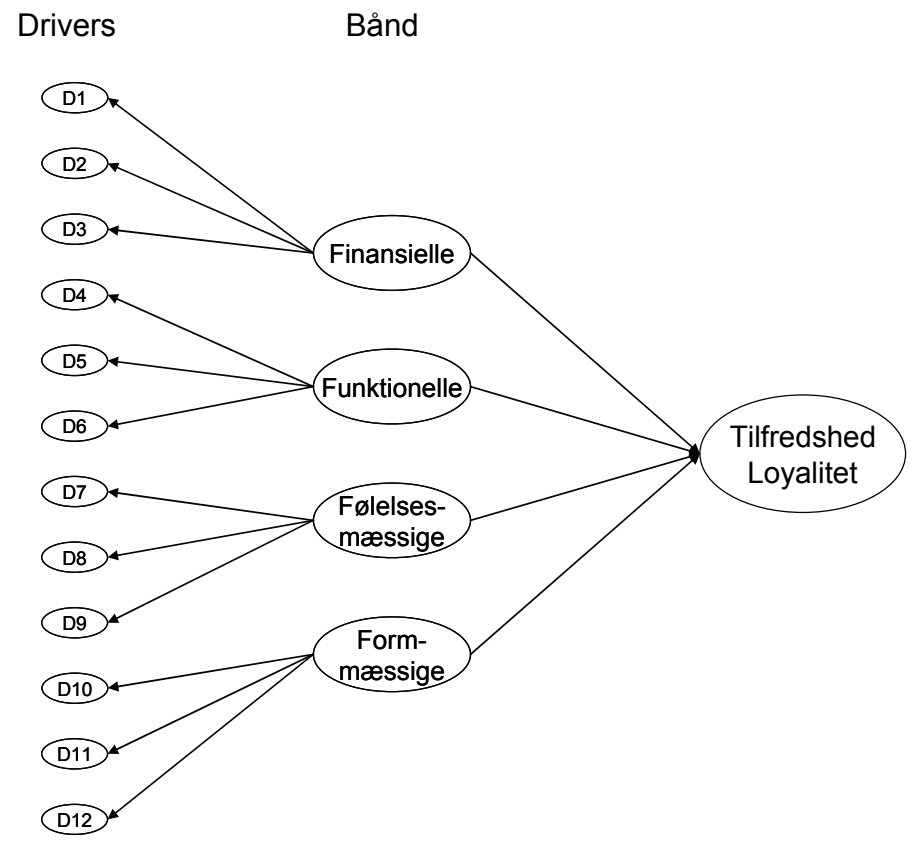

Figur 8: RelationScore modellen 


\section{Gruppe 6: Løbende opsamling afforbrugerreaktioner}

Nogle gange henvender forbrugere sig uopfordret til en virksomhed. Den hyppigste årsag hertil er en klage, men det kan også være for at udtrykke tilfredshed eller komme med forslag til produktforbedringer eller nye produkter.

De færreste mennesker kan lide klager, men der er generel forståelse for, at det er vigtigt at behandle forbrugerklager seriøst, og at en seriøs behandling af en forbrugerklage kan transformere en utilfreds kunde til en loyal kunde. Men denne form for uopfordret henvendelse fra forbrugerne er også en vigtig informationskilde, der kan nyttiggøres i forbindelse med forbrugerorienteret innovation. At klager samtidig indeholder information, der kan føre til produktforbedringer eller nye produkter, har været kendt længe, og har fundet udtryk i begrebet complaint management, som dækker over virksomhedens strategiske nyttiggørelse af klageprocessen (Fornell \& Wernerfelt, 1988; Hansen et al., 1995). Her er det alment anerkendt at en sådan form for 'klageledelse' har to hovedkomponenter: for det første at behandle klager på en for den klagende forbruger tilfredsstillende måde, og for det andet at viderebearbejde den gennem klagen indkommende information på en sådan måde, at den kan nyttiggøres $i$ innovationsprocessen. Erkendelsen af nytten af denne type information har også ført til, at det tit er blevet et mål i klageledelsesprocessen at opmuntre forbrugerne til at klage, mest ved at etablere og promovere kommunikationskanaler, der er lette at bruge for forbrugeren, og som gør det klart, hvorhen en klage skal rettes.

Der er dog samtidig en erkendelse af, at brug af disse informationer skal ske varsomt. Det er altid kun et mindretal af de utilfredse forbrugere, der faktisk klager, og dem der klager kan almindeligvis ikke betragtes som repræsentative for forbrugerne i almindelighed (Stephens \& Gwinner, 1998). Information, der kommer ind gennem klager og forslag, kan derfor danne vigtig inspiration i innovationsprocessen, men skal almindeligvis sikres gennem andre former for oplysninger, før man committer større ressourcer. På denne måde ligner de klagende forbrugere en lead user gruppe, jvf. den tidligere diskussion om denne brugergruppe.

Nogle gange bliver behandlingen af klager integreret $i$ en speciel afdeling i virksomheden, der skal tage sig af forbrugerforhold. Tanken om denne type afdelinger blev for ca. 30 år siden lanceret i USA under betegnelsen consumer affairs departments (Fornell, 1978) og var hovedsagelig ment som en proaktiv håndtering af den forbrugerpolitiske 'trussel': ved at integrere dialogen med forbrugerne $i$ virksomhedens organisation tager man selv vare på eventuelle problemer i forhold til forbrugerne $\mathrm{i}$ stedet for at overlade dem til offentlig regulering. Ud over modtagelsen og bearbejdningen af forbrugerhenvendelser kan sådanne afdelinger også have ansvaret for forbrugerrettet kommunikation (fx gennem brugsanvisninger), relationer til medier og offentlige myndigheder angående forbrugerforhold, og virksomhedsintern videreuddannelse i forbrugerorientering 
og forbrugerforhold (Hansen \& Stauss, 1985). Tanken omkring sådanne afdelinger er slået igennem mest i USA, hvor ansatte i denne type afdelinger er organiseret i Society for Consumer Affairs Professionals in Business.

Sådanne afdelinger institutionaliserer dialogen med forbrugerne i virksomheden og kan derfor være et nyttigt supplement til nogle af de andre omtalte redskaber. Uopfordrede henvendelser fra forbrugerne er en værdifuld og omkostningsfri informationskilde til virksomheden, som kan udnyttes til at belyse især den horisontale dimension af Forbrugerkvalitetsmodellen. En sådan afdeling kan desuden også tage sig af anvendelsen af nogle af de andre her omtalte redskaber, så at informationsstrømmen ind i virksomheden dækker alle grupper af forbrugere, ikke kun dem der henvender sig af egen drift, for at udligne hovedvægten på oplysninger, der er mere relevante for marginale forbedringer frem for egentlige innovationer. 


\section{Cases ${ }^{1}$}

I det følgende beskriver vi 7 virksomhedscases, hvor nogle af de ovenfor omtalte redskaber er blevet taget $\mathrm{i}$ anvendelse. I hver case gennemgås virksomheden, problemstillingen, den valgte metode, resultaterne og deres anvendelse, og til sidst en evaluering.

\subsection{Amager Strandpark}

Brug af fokusgrupper for øget brugerinvolvering i planlægningen af en ny storbystrand. $^{2}$

Virksomhedsbeskrivelse

Ny Amager Strand er en storbystrand, der ejes af Københavns Kommune, Københavns Amt og Frederiksberg Kommune. Ejerne har dannet interessentskabet Amager Strandpark I/S. Amager Strand ligger fem kilometer fra Rådhuspladsen i København. At stranden er placeret så centralt betyder, at der befinder sig mere end 500.000 mennesker inden for en afstand på $10-12 \mathrm{~km}$.

I 2003 blev Amager Strandpark I/S etableret med det formål at bygge og drive en ny strand. Der har været en strand på Amagers østkyst siden 1930'erne. På grund af mange problemer med den daværende strand blev der i 1980'erne sat planer i værk for at få realiseret en ny og bedre strand. I sommeren 2005 blev den nye strand indviet på Amager.

Amager Strandparks ledelse valgte at anvende fokusgrupper til inddragelse af borgerne i udviklingsprocessen. Denne metode blev valgt, da det er en metode til hurtigt og billigt at indsamle kvalificerede oplysninger om brugernes behov og ønsker til den nye strand. På trods af at den nye strand først blev indviet i sommeren 2005, har den allerede vist sig at være en stor succes.

Problemstilling

Amager Strand har altid været en meget populær strand. I starten af 1980'erne begyndte borgere, lokale klubber og foreninger dog at vise interesse i at få anlagt en ny strand, da der var for mange problemer med den daværende. Problemerne bestod primært i, at der var lav vandstand, hvilket altid havde medført problemer. Den gamle strand var en kunstig anlagt badestrand fra 1930'erne. Der havde igennem alle årene været et

\footnotetext{
${ }^{1}$ Jeg takker Henriette Boel Nielsen for hendes uundværlige hjælp med udarbejdelsen af casene.

${ }^{2}$ Udarbejdet ud fra interview med projektleder for Amager Strandpark Tove Frederiksen.
} 
behov for konstant at fylde mere sand på stranden, idet strøm og højvande førte sandet ud i Øresund. Ud over at tilføre stranden 95.000 kubikmeter sand for at udbedre forholdene, havde man også forsøgt at opføre en spunsvæg, der skulle holde på vandet. Ingen af disse tiltag viste sig dog at hjælpe.

Der var således en del krav til den nye strand, som skulle være længere, have en større vanddybde og højere badevandskvalitet. Den måde Amager Strandpark valgte at opfylde disse krav på, var ved at anlægge en kunstig ø på samme område, men længere ude i Øresund. Anlæggelsen af denne nye $\varnothing$ gjorde det muligt at få en bredere, mere stabil og længere strand, som strakte sig ud til bedre og dybere badevand, hvor bølgerne kunne holde på sandet.

Da projektet om at etablere en ny Amager Strand i 2003 blev politisk godkendt, fandt Amager Strandparks ledelse det meget vigtigt, at der skulle findes en effektiv og billig metode til at inddrage borgerne så meget som muligt i udviklingsprocessen. At denne brugerinddragelse var så vigtig for Amager Strandpark skyldtes, at det vigtigste formål med stranden var at opfylde borgernes ønsker og behov.

Metode

En fokusgruppe er et forum, hvor brugerne diskuterer holdninger til koncept, indhold, design og funktionaliteter. Diskussionen kan være i forhold til et allerede eksisterende koncept, hvor man ønsker at forbedre konceptet, eller det kan være i forhold til et nyt koncept, hvor man ønsker at lade brugerne komme med deres forslag til kvalitet og indhold. Idet brugerne $\mathrm{i}$ fokusgruppen kan bygge videre på hinandens idéer, opstår der ofte nye former for indsigt, der kan give et godt inspirationsgrundlag for udviklingsprocessen.

Amager Strandpark valgte at anvende en fokusgruppe, idet metoden opfyldte kravene om hurtigt og billigt at kunne indsamle kvalificerede oplysninger om, hvad brugerne ønskede sig af stranden. Fokusgruppen, der bestod af 11 interesserede borgere, var bredt sammensat under hensyn til alder, køn, uddannelse og geografisk tilhørsforhold. Den måde hvorpå Amager Strandpark fandt frem til de personer, der skulle indgå i fokusgruppen, var ved at annoncere efter interesserede borgere i de lokale aviser. Dette gav hurtig respons og efter interviews med nogle af de relevante personer, der havde henvendt sig, blev personerne til fokusgruppen udvalgt.

Amager Strandpark valgte primært at anvende fokusgruppen i de første faser af udviklingsprocessen. I stedet for først at udvikle et produkt og herefter få det til diskussion i fokusgruppen ønskede man, for at undgå unødige omkostninger, at fokusgruppen skulle inddrages så tidligt som muligt.

Der blev i alt afholdt to workshop-runder for fokusgruppen. Den første workshop-runde blev afholdt i august 2003, hvilket var inden projek- 
tet endnu var blevet politisk godkendt. Anden workshop-runde blev afholdt i februar 2004, nogle måneder inden at selve anlægsarbejdet gik i gang. Inden den første workshop blev respondenterne i fokusgruppen bedt om, at de i deres sommerferie skulle tage billeder af det, som de anså som den perfekte strand. Disse billeder blev brugt som inspiration i den første workshop. Derefter skulle fokusgruppen arbejde med ideer og visioner til den nye strand. Den anden workshop-runde byggede videre på den første workshop-runde, og her skulle der arbejdes med værdier, regler og rammer for stranden. For at fokusgruppen havde mulighed for at komme med kvalificerede forslag til den nye strand, var både teknikere, planlæggere og andre fagfolk til rådighed for fokusgruppen under begge workshop-runder.

For at sikre at fokusgruppen kunne arbejde uafhængigt af Amager Strandpark I/S, var processen styret af en ekstern konsulent.

Fokusgruppen er ikke den eneste metode, der er blevet brugt til at høre borgernes stemme i udviklingen af Ny Amager Strand. Der har løbende været dialog med de lokale borgere, mange beslutninger har været $\mathrm{i}$ offentlig høring, og der har desuden været en spørgeskemaundersøgelse blandt 1000 borgere i området. Det har dog været fokusgruppen, der er fremkommet med de mest strukturerede og anvendelige ideer til den ny strand.

Resultater

Arbejdet med fokusgruppen resulterede $\mathrm{i}$ to indstillinger, en fra hver workshop-runde. I den første workshop-runde, som var mere overordnet end den anden, kom fokusgruppen frem til følgende vision for den ny strand: 'Københavns bedste åndehul med rummelighed, alsidighed, innovation og cestetik'. Indstillingen tog udgangspunkt i tre temaer: rammer, tryghed og oplevelser. Den anden indstilling havde lidt flere konkrete forslag til, hvordan fokusgruppen ønskede, at Ny Amager Strand skulle tage sig ud. Her var der konkrete forslag omkring tonen, vejledning og nødvendige forbud. Fokusgruppens samlede anbefalinger til Amager Strand ses i tabel 2. 
Tabel 2: Sammenfatning af fokusgruppens to indstillinger til Amager Strand

Resumé over fokusgruppens anbefaling til Amager Strand

- Rammer - vi ønsker at fastholde indtrykket af natur, bevare et frit udsyn og skabe forskellige rum, der kan glæde flest mulige borgere.

- Tryghed - Amager Strandpark skal være overskuelig, og man skal føle sig godt vejledt. Strandparken skal være et trygt sted at komme året og døgnet rundt.

- Oplevelser - Amager Strandpark skal være et sted for så mange som muligt og skal have plads til et alsidigt udbud af oplevelser og aktiviteter. Muligheden for oplevelser er skabt af de rigtige rammer, og ved at stranden er et trygt sted at komme.

- Tonen - vi ønsker en positiv tone på Amager Strandpark. Det skal være en tone, der lægger op til, at man tager hensyn til hinanden, så stranden bliver et dejligt sted at være for alle. Den positive tone skal slås an i foldere, på oversigtskort, hjemmeside, i regelsæt og andet materiale om stranden. F.eks. med forklaring om hvad man godt må, frem for hvad man ikke må.

- Vejledning - Amager Strandpark skulle gerne i sig selv være et overskueligt og åbent sted, men det vil naturligvis være nødvendigt med en vis vejledning. Vejledning skal forstås i bred forstand. Det er de pejlemærker og oplysninger man orienterer sig efter før besøget, på vej til at slå sig ned og under opholdet på stranden.

- Nødvendige forbud - man kan komme langt med en positiv tone, vejledning og diskret skiltning, men vi står alligevel tilbage med enkelte sager, som kræver regler eller et egentligt forbud (hunde, windsurfere, motoriserede køretøjer, erhverv og aktiviteter)

Kilde: Amager Strand kernekoncept: Dogmer \& udfordringer, mål \& strategier for drift \& aktiviteter på Amager Strand.

I anbefalingerne foreslås der eksempelvis, at stranden skal fokusere på, hvad der er tilladt frem for forbud. Så i stedet for at have et skilt hvor der står "boldspil forbudt", skal der henvises til et område, hvor boldspil er tilladt.

\section{Anvendelsen}

Amager Strandpark har i høj grad anvendt resultaterne fra fokusgruppen. I første omgang blev indstillingerne anvendt som inspirationskilde og som retningslinie for udvikling af stranden. Løbende i denne proces var der dog forskellige beslutningsgrundlag, der skulle overholdes. Der blev eksempelvis fremsat et krav til fokusgruppen om, at der skulle være 1000-1400 parkeringspladser et eller andet sted ved Amager Strand. Det var så fokusgruppens opgave at komme med forslag til, hvor disse parkeringspladser skulle placeres. Alle steder hvor det var muligt at inddrage fokusgruppens idéer, blev det gjort.

Efter at have anvendt fokusgruppens indstillinger i de første af projektets faser, blev indstillingerne også anvendt i forskellige senere beslutnin- 
ger og som tjekliste for, om alt var husket. Da Ny Amager Strand stadig ikke er helt færdigudviklet endnu, benytter Amager Strandparks ledelse sig stadigvæk af indstillingerne og tager dem med ind i beslutninger.

Som eksempel på nogle af fokusgruppens forslag, der er blevet implementeret, kan nævnes, at stranden er blevet sådan, at biler kun har begrænset adgang til stranden, windsurfere har deres eget område i vandet, der er etableret kontakt med natteravnene, der gøres kun i lille omfang brug af forbudsskilte, der gøres brug af piktogrammer og der er undgået massiv og "Tivoli-agtig" skiltning.

Ingen af fokusgruppens forslåede tiltag var urealistiske, hvilket medførte, at de fleste forlag blev anvendt i udarbejdelsen af den endelige strand.

\section{Evaluering}

Amager Strandpark har haft rigtig gode erfaringer med at anvende fokusgruppen i produktudviklingen. At Amager Strandpark har haft oplysninger omkring borgernes ønsker og behov tidligt i processen, har gjort det muligt, at projektet blev færdigt til tiden og samtidig overholdte anlægsbudgettet.

Hvorvidt den nye Amager Strand bliver en succes, vil først rigtigt vise sig i løbet af de næste par år. Dog har der været så stor interesse for den nye strand, at dele af stranden åbnede allerede før indvielsen i sommeren 2005.

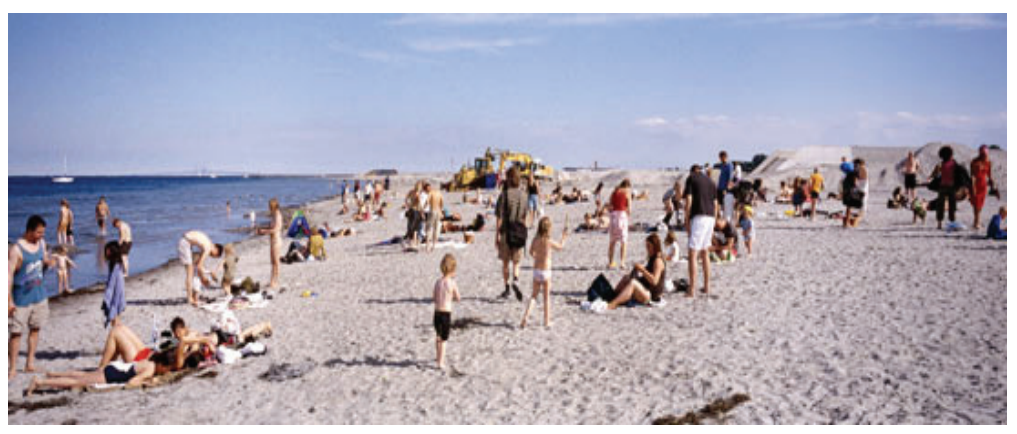

Figur 9: Strandliv i juni 2005

At der er stor tilfredshed med stranden, har Amager Strandpark oplevet, da de efter indvielsen har modtaget mange takkebreve fra yderst tilfredse borgere i Københavnsområdet.

Fokusgrupper bliver normalt anvendt, når større virksomheder udvikler produkter. Det er første gang i Danmark, at en fokusgruppe har været anvendt som rådgiver for en offentlig bygherre i Danmark. Ledelsen hos Amager Strandpark har en formodning om, at fokusgrupper vil blive anvendt langt mere til offentlige anlægsprojekter i fremtiden.

Amager Strandparks anvendelse af fokusgruppemetoden går en del udover den måde, den for det meste bliver brugt på i udviklingsøjemed. Den samme gruppe er således blevet brugt to gange $\mathrm{i}$ to forskellige stadi- 
er i udviklingsforløbet for at kunne få input svarende til forskellige konkretiseringsgrader. At gruppen skulle komme frem med egentlige indstillinger til bygherren, giver gruppen en meget mere forpligtende funktion, end man almindeligvis gør. Også kendsgerningen at gruppen havde adgang til en række eksperter, der tog sig af projektets udformning, gør, at fokusgruppemetoden er blevet videreudviklet til noget, der mere minder om brugercentreret design. Det er samtidigt klart at denne form for fokusgruppeforløb stiller store krav til de deltagende forbrugere, som skulle bruge en del tid og ressourcer, og at den derfor kun kan bruges i projekter med en stor (for-)brugerinteresse

Det skal også nævnes, at fokusgruppen er blevet suppleret med et større kvantitativt survey, hvilket tager højde for det, der måske er fokusgruppemetodens hovedproblem i innovationssammenhæng, nemlig at det er farligt at generalisere alt for meget ud fra en lille gruppe mennesker.

\subsection{Nutana}

Anvendelse af laddering interview i udviklingen af nye færdigretter til børn. ${ }^{3}$

Virksomhedsbeskrivelse

Nutana er en mindre dansk fødevarevirksomhed, der producerer fødevarer uden brug af kunstige aroma- og tilsætningsstoffer. Virksomheden blev grundlagt i 1898 og er i dag Skandinaviens største producent af vegetabilske fødevarer. Nutana producerer en række traditionelle vegetariske produkter. Nutanas produktsortiment kan deles op i fire kategorier: konserves, morgenmad, tørkolonial og dybfrost.

Nutanas slogan er "Nutana - ren smag". Med dette ønsker Nutana at kommunikere "ærlig og sund mad" til forbrugerne. "Ærlig og sund mad" dækker over mad, hvor ingredienserne svarer til dem, som allerede kendes i ethvert privat køkken. Virksomhedens mål er at slå sig fast på markedet for snack og tilbehør.

I 1999 igangsatte Nutana et projekt med det formål at udvikle dybfrosne retter til børn og unge baseret på danske økologiske grøntsager. I løbet af produktudviklingsprocessen blev der gennemført fokusgrupper, laddering interviews og en smagstest med børnene.

Problemstilling

Årsagen til at Nutana satte fokus på at udvikle nye produkter til produktsortimentet skyldtes, at der var et pres fra både kunderne og ledelsen herom. Kunderne, som især var indkøbere i detailhandlen, ønskede nye produkter til hylderne, mens Nutanas ledelse gerne ville af med virksomhedens lidt støvede image og derfor ønskede smartere og mere trendy

\footnotetext{
${ }^{3}$ Casen er hovedsageligt baseret på Søndergaard (2004)
} 
produkter. Det støvede image skyldtes, at virksomheden i en årrække ikke havde haft de store innovative produktudviklinger. De fleste produktudviklinger havde indtil nu været forbedringer af eksisterende produkter og forbedrede udgaver af konkurrentprodukter. Det var således små produktforbedringer, der ikke virkede som nye produkter for forbrugerne. Problemet for Nutana var, at virksomheden ikke havde meget tradition for at indsamle eller anvende markedsinformation til produktudviklingen. Mere viden om markedet generelt og især om forbrugertrends skulle bruges både som inspirationskilde til nye ideer og til vurdering af de ideer, der opstår.

Metode

Det centrale instrument, som blev taget i anvendelse i produktudviklingsforløbet, var laddering interviews. Grundidéen bag laddering interviews er, at forbrugeren køber produkter, fordi produkterne har nogle egenskaber, der har en positiv konsekvens for forbrugeren. Disse konsekvenser er vigtige for forbrugerne for at få opfyldt vaerdier. Det købte produkt er derfor ikke et mål i sig selv, men et middel til at opnå andre og højere mål. Laddering teknikken anvendes i personlige interviews og går ud på, at respondenten ikke kun udspørges om, hvilke egenskaber ved et produkt der er vigtige, men også hvorfor netop disse egenskaber er vigtige. Interviewet fortsætter indtil der er opnået viden om, hvordan forbrugeren knytter produktet til sine personlige værdier. En sådan analyse kan være særlig interessant for en virksomhed som Nutana, der producerer produkter, som der er stærke holdninger til.

Der blev genereret forbrugerinput i fire trin. 'Forbrugere' er her både børn og voksne, fordi produktet hovedsageligt retter sig til børn, men indgår selvfølgelig i den måltidsplanlægning, som forældrene foretager.

I første trin blev der afholdt fokusgrupper med børn og voksne for at få en fornemmelse af deres holdninger, erfaringer og meninger i forhold til spisning af grøntsager. På baggrund af resultaterne derfra blev der defineret seks overordnede produktkategorier, som er vist i tabel 3 .

I andet trin blev disse seks produktkategorier brugt som udgangspunkt for laddering interviews med forældre. Forældrene skulle rangordne de seks produktkategorier "hvis du stod $i$ supermarkedet og havde disse seks produkter at valge efter". De skulle så begrunde deres rangordning og disse begrundelser dannede udgangspunkt for selve laddering processen. 
Tabel 3: Indledende produktkategorier

Frosne, økologiske grøntsager (fx en grøntsagsblanding).

Produktet kan bruges af hele familien som tilbehør til aftensmaden.

Friske, økologiske grøntsager.

De kan bruges af hele familien som tilbehør til aftensmaden (af den slags du normalt køber)

Frosne, økologiske grøntsager (fx en grøntsagsblanding).

Produktet er beregnet til børn og kan bruges som tilbehør til aftensmaden.

En frossen færdigret, baseret på økologiske grøntsager.

Produktet er beregnet til børn og kan bruges som et aftensmåltid.

Et produkt, der er baseret på frosne, økologiske grøntsager, og som kan bruges som mellemmåltid.

Produktet er beregnet til børn. (fx mini-pizza eller grøntsags-is)

Et produkt, der er baseret på friske, økologiske grøntsager, og som kan bruges som mellemmåltid (fx forskellige minigrøntsager). Produktet er beregnet til børn.

På baggrund af resultaterne fra disse laddering interviews blev der udviklet syv produktkoncepter, som skulle danne grundlag for en anden omgang laddering interviews (trin 3). I sidste trin blev der fremstillet prototyper, som blev smagstestet blandt børn og et familiepanel.

\section{Resultater}

Resultater fra laddering interviews præsenteres oftest i form af såkaldte hierarkiske værdikort. Figur 10 viser et eksempel på et hierarkisk værdikort, som fremkom efter den første runde laddering interviews. Eksemplet viser, hvad forbrugerne associerede med produktkategorien 'frosset tilbehør til hele familien.'

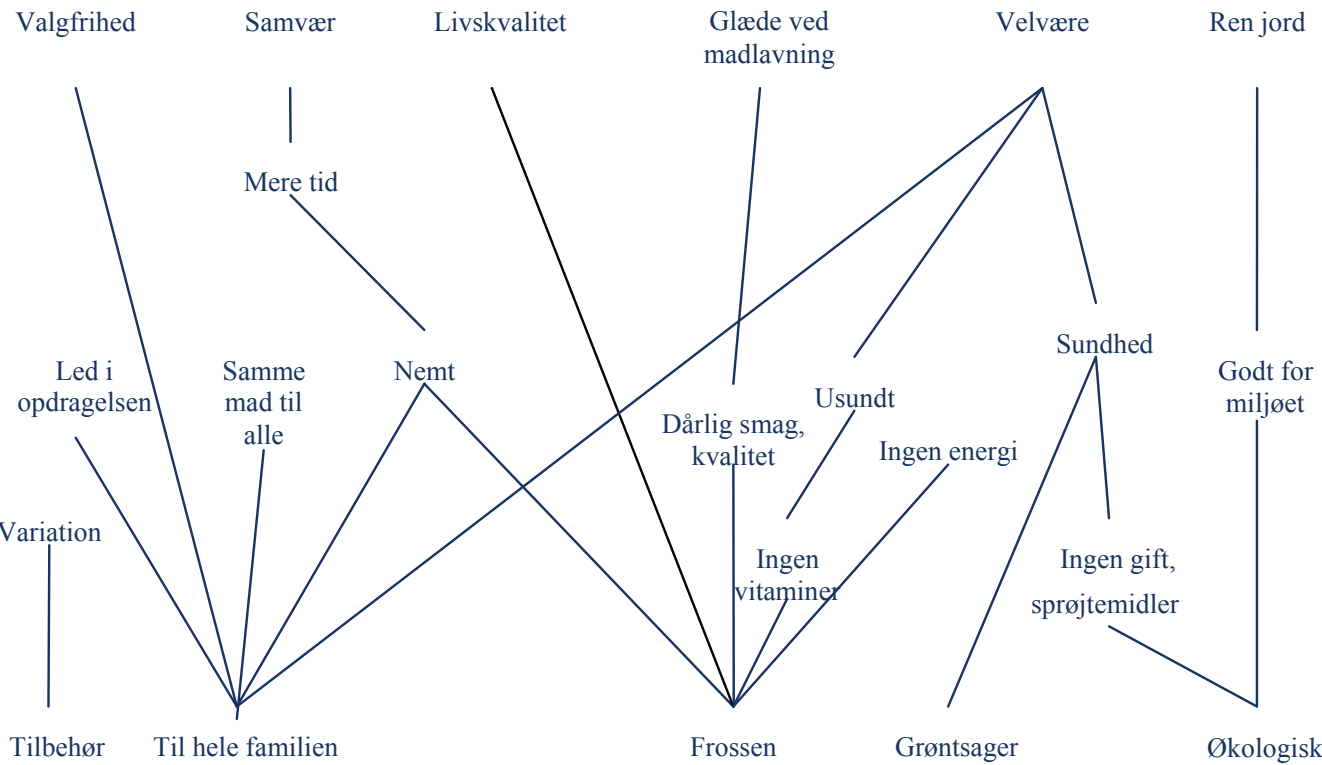

Hierarkisk værdikort for "Frosset tilbehør til hele familien"

Alle hierarkiske værdikort viste, at "sundhed" spiller en meget centrale rolle for, hvordan forældrene vurderer disse produkter. Herudover var god mad, nemt og samme mad til alle i husstanden begreber, der gik igen 
i alle kortene. Fra dette kan det udledes, at respondenterne søger nem og velsmagende mad, som alle kan lide. Glæde ved madlavning, samvær, velvære og valgfrihed er vardier, der går igen i alle kort. Respondenterne foretrækker således mad, som man kan være sammen om og få en god oplevelse ud af, samtidig med at der er nogle valgmuligheder.

Inspireret af disse resultater udviklede Nutana syv produktkoncepter, som er vist i tabel 4. I tabellen er også gengivet de 'stiger', som laddering interviewene resulterede i, og som Nutana troede var relevante for det pågældende produktkoncept - både positive og negative.

Tabel 4: Nutanas produktkoncepter

\begin{tabular}{|c|c|c|c|c|}
\hline Produkttype & Navn & Ingredienser & Emballage & Laddering-stiger \\
\hline $\begin{array}{l}\text { Frosset tilbe- } \\
\text { hør til familien }\end{array}$ & $\begin{array}{l}\text { Økologisk indianer- } \\
\text { blanding (wok ret) }\end{array}$ & $\begin{array}{l}\text { ÆErter, gulerød- } \\
\text { der, majs }\end{array}$ & Evt. familieportion & $\begin{array}{l}\text { + hele familien -> nemt-> sam- } \\
\text { vær- frosset -> ingen vitaminer-> } \\
\text { usundt (skal præciseres på } \\
\text { emballagen) }\end{array}$ \\
\hline \multirow{2}{*}{$\begin{array}{l}\text { Frossen } \\
\text { mellemmåltid } \\
\text { til børn }\end{array}$} & $\begin{array}{l}\text { Trafikpinde (stegte } \\
\text { kroketter) }\end{array}$ & $\begin{array}{l}\text { ÆErter, gulerød- } \\
\text { der (evt. spinat) }\end{array}$ & Kroketter på pind & $\begin{array}{l}\text { + tilbehør/sund snack- frossen -> } \\
\text { ingen vitaminer-> usundt }\end{array}$ \\
\hline & Grøntsagsautomat & ÆErter (evt. majs) & $\begin{array}{l}\text { Løsfrosne i pez- } \\
\text { agtig automat }\end{array}$ & $\begin{array}{l}\text { + sund snack- frosset -> ingen } \\
\text { vitaminer-> usundt }\end{array}$ \\
\hline \multirow[t]{3}{*}{$\begin{array}{l}\text { Frossen } \\
\text { færdigret til } \\
\text { børn }\end{array}$} & $\begin{array}{l}\text { Bimmers brocco- } \\
\text { li(pastaret) }\end{array}$ & $\begin{array}{l}\text { Broccoli og } \\
\text { mælkesauce }\end{array}$ & $\begin{array}{l}\text { Bakke med børne- } \\
\text { motiv }\end{array}$ & $\begin{array}{l}\text { + pastaret: (piger 6-9 år) - foræl- } \\
\text { dre er generelt negative overfor } \\
\text { færdigretter. Har produktet allige- } \\
\text { vel en chance hos forældre/børn? } \\
\text { (skal testes) + kan anvendes som } \\
\text { tilbehør -> valgfrihed }\end{array}$ \\
\hline & $\begin{array}{l}\text { Skipper Skræk- } \\
\text { lasagne }\end{array}$ & $\begin{array}{l}\text { Spinat og kogte } \\
\text { pastaplader i lag } \\
\text { med mælke- } \\
\text { sauce }\end{array}$ & & $\begin{array}{l}\text { + lasagne er børns livretter (6-11 } \\
\text { år) +/- spinatsmag for børn }\end{array}$ \\
\hline & $\begin{array}{l}\text { Space pasta (pastaret } \\
\text { evt. pasta i figurer) }\end{array}$ & $\begin{array}{l}\text { Grøntsager kan } \\
\text { varieres efter } \\
\text { behov og mild } \\
\text { tomatsauce }\end{array}$ & & $\begin{array}{l}+ \text { kan anvendes som tilbehør -> } \\
\text { valgfrihed }\end{array}$ \\
\hline $\begin{array}{l}\text { Frosset tilbe- } \\
\text { hør til børn }\end{array}$ & Kartoffelhoveder & Kartoffelskiver & Pose/bakke & $\begin{array}{l}\text { frosset -> nemt -> samvær + } \\
\text { tilbehør -> valgfrihed (kan også } \\
\text { anvendes som tilbehør til voksne) }\end{array}$ \\
\hline
\end{tabular}

Produktkoncepterne i tabel 4 blev brugt $i$ en anden runde laddering interviews, som førte til en optimering af koncepterne og til udvælgelse af kartoffelhoveder, spinatlasagne, indianerblanding og trafikpinde. Disse blev så smagstestet og herefter rangordnet af børn og et familiepanel/forældrepanel. I tabel 5 ses resultatet af smagstestene.

Tabel 5: Resultater af smagstest

\begin{tabular}{lcc}
\hline Produkt & \multicolumn{2}{c}{ Rangorden } \\
\cline { 2 - 3 } & Forældre & Børn \\
\hline Kartoffelhoveder & 1 & 1 \\
Indianerblanding & 2 & 2 \\
Trafikpinde & 3 & 2 \\
Spinatlasagne & 1 & 3 \\
\hline
\end{tabular}


På trods af at kartoffelhoveder var det produkt, der blev rangordnet højest af både børnene og familiepanelet, så valgte Nutana ikke at arbejde videre med dette produkt. Nutana vurderede, at der var tale om et produkt, som de ikke ville være i stand til at tjene penge på, da der i forvejen var mange udbydere af dette produkt. Indianerblandingen, som havde fået en anden plads i rangordningen, vurderede Nutana ikke kunne blive en succes, da det var en type mad, som de fleste familier selv kunne lave i køkkenet. Spinatlasagnen var forældrene meget begejstrede for, men da børnene tilsyneladende ikke syntes om produktet, så ville det næppe blive en succes. Det produkt som Nutana valgte at arbejde videre med, var således et Trafikpinde-lignende produkt. For at få forældrene til at acceptere produktet var det vigtigt at modificere produktet således, at det kunne spises af hele familien uden at være for "børne-agtigt". Dette var oplysninger, som Nutana havde ud fra de hierarkiske værdikort.

\section{Anvendelsen}

Som resultat af fokusgrupperne, laddering interviewene og de afsluttende smagstests udviklede Nutana blandt andet Nutana Croquetter og Nutana Chili Bites, der ses i figur 11. For at gøre Trafikpindene attraktive for hele familien havde Nutana således valgt at fjerne pinden i produktet og tilsætte flere forskellige typer af grøntsager.

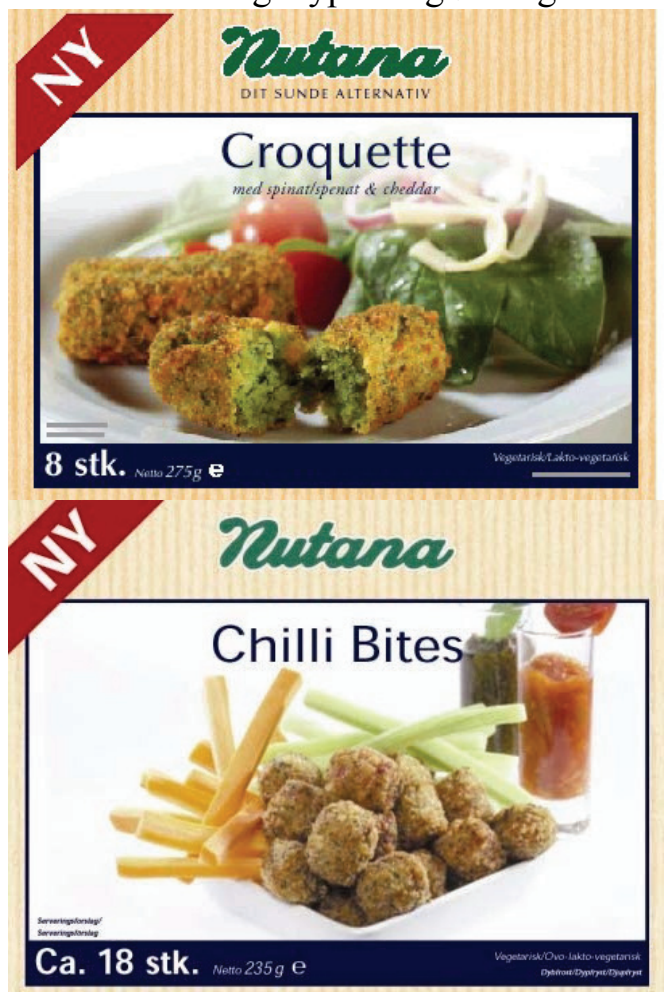

Figur 11: Resultatet af produktudviklingsprocessen: Kroketter og Bites 
Udover forskellige typer af kroketter og bites blev de resultaterne også brugt som en inspirationskilde til udviklingen af andre produkter. Nutana har herudover anvendt informationerne fra analysen til at vurdere, hvorvidt Nutanas eksisterende produkter er i overensstemmelse med brugernes ønsker og behov.

\section{Evaluering}

Der var her tale om et ambitiøst forsøg, hvor en mindre virksomhed prøvede at opnå en større grad af forbrugerorientering gennem anvendelse af en række redskaber, der tillader bedre indsigt i forbrugernes vurderinger. Det var især den første runde laddering interviews, som virksomheden opfattede som meget inspirerende, og hvor resultaterne opfattedes som troværdige og relevante.

Nutana, der før i tiden ofte tog afsæt i konkurrenternes produkter, når der skulle udvikles nye produkter, har via arbejdet med laddering resultaterne formået at sætte fokus på forbrugerne. Således håber virksomheden på, at de nye produkter kan hjælpe Nutana til at komme af med det lidt støvede image.

Arbejdet med laddering resultaterne har gjort Nutanas udviklingsteam mere fortrolig med, hvordan man anvender markedsinformation i produktudviklingen. Udviklingsteamet har formået at overføre resultaterne fra de hierarkiske værdikort til inspiration til produktudviklingen. Herudover har informationerne fra analyserne givet deltagerne i udviklingsprojektet en fælles forståelsesramme, således at de har kunnet "tale samme sprog”. Nutanas udviklingsteam har dermed også opnået viden om, hvordan de kan strukturere deres udviklingsprojekter i fremtiden.

Casen viser også, at der er virksomhedsspecifikke forskelle i, hvor i produktudviklingsforløbet sådanne oplysninger bør indgå, og hvordan forskellige redskaber skal kombineres. I en fødevarevirksomhed som Nutana er det for eksempel vigtigt, at der indarbejdes en smagstest i et forbrugerorienteret produktudviklingsforløb.

\section{$3.33 \mathrm{M}$}

Anvendelse af lead user metoden til produktudvikling på industrielle markeder. ${ }^{4}$

Vi bruger denne case til at illustrere lead user metoden, selv om den ikke omhandler produkter til et forbrugermarked. Stort set alle dokumenterede cases omkring lead user metoden vedrører industrielle markeder.

Virksomhedsbeskrivelse

$3 \mathrm{M}$ er en diversificeret teknologivirksomhed, der producerer innovative produkter og services. 3M's produktsortiment spænder fra industrielle

\footnotetext{
${ }^{4}$ Baseret på Hendersen, 2000; Lilien et al., 2002; von Hippel \& Sonnack, 1999
} 
produkter som fiberoptiske forbindelser, slibematerialer og medicinske produkter, til rengøringsprodukter, Post-it Notes, Thinsulates m.v., der anvendes på forbrugermarkedet.

3M, der blev grundlagt i 1902, har hovedkontor i Minnesota, USA. På verdensplan er der ansat over 70.000 mennesker til at udvikle, fremstille og sælge de cirka 50.000 forskellige produkter. 3M har en årlig omsætning på 20 milliarder dollar.

Koncernen har tradition for nytænkning på alle områder og niveauer, og der er stor fokus på at udvikle nye produkter til kunderne. Dette underbygges af koncernens innovationsmål, som er, at $30 \%$ af omsætningen hvert år skal komme fra produkter, som er mindre end 5 år gamle.

I 1996 fik 3M's produktudviklingsspecialister, gennem et in-house foredrag, indsigt $i$ lead user metoden. Ud fra dette vurderede $3 \mathrm{M}$, at lead user processen var en af de produktudviklingsmetoder, der kunne gøre det muligt for koncernen at virkeliggøre innovationsmålet på $30 \%$.

Problemstilling

I midten af 1990'erne indså 3M's ledelse, at den nuværende produktudviklingsstrategi ikke var stærk nok til at bidrage med signifikant vækst $i$ fremtiden. 3M's produktudviklinger var efterhånden kun små produktforbedringer af eksisterende produkter, og der var færre og færre innovative produktudviklinger.

$3 \mathrm{M}$ klarede sig godt, hvad angik teknologidrevne produktudviklinger. Det var specielt ved de brugerdrevne produktudviklinger, at $3 \mathrm{M}$ havde store problemer. Denne erkendelse var dog ingen overraskelse for 3M's ledelse. Koncernen havde altid betragtet sig selv som mere teknologidrevet end brugerdrevet, og der var derfor også ansat mange flere mennesker i R\&D end i marketingafdelingen. Ledelsen var dog efterhånden begyndt at betragte problemet som stort og indså, at der var store muligheder for vækst i nogle af de markeder, som der på nuværende tidspunkt ikke var fokus på. Disse markeder skulle erobres med produkter, der var udviklet på baggrund af teknologisk indsigt, men også med dyb indsigt i nye kundebehov.

Manglen på innovative produktudviklinger skyldtes herudover den tilgangsvinkel, som 3M havde til brugerdrevet produktudvikling. Produktudviklingsafdelingen fik nye ideer ved at udspørge de traditionelle kunder om, hvad de ønskede sig af eventuelle nye produkter. Dette resulterede mest i oplysninger, der alene kunne bruges til forbedringer af eksisterende produkter og var således ikke den rette metode til at få brugeroplysninger, der skulle medføre større innovationer.

Et af de områder, hvor 3M så mulighed for at øge den på daværende tidspunkt stagnerende vækst, var inden for kirurgiske operationsafdækninger. Operationsafdækninger er et tyndt stykke plastic film, der klæber sig til patientens hud under operationen, og som anvendes for at undgå infektion. 


\section{Metode}

Lead users er virksomheder, organisationer eller individer, der er foran, hvad angår markedstrends, og som har nogle behov, som de eksisterende produkter på markedet ikke opfylder. Lead user metoden er en proces, hvor man prøver at nyttiggøre viden om og fra disse brugere for at opnå inspiration til nye produkter med en større innovationsgrad.

Almindeligvis gennemgås fire faser som en del af lead user processen:

- Identificere trends og brugerbehov: Her kontaktes eksperter, som har viden om både omfanget af markedet, men også om nye teknologier og praksis på markedet.

- Identificere lead users: Her søges der, ved hjælp af netværkskontakt, efter individer og grupper, der ligger lige på kanten af det efterforskede område, og som derfor har en viden, der kan være anvendelig i processen. Ved identificering af lead users er det meget normalt, at disse personer dukker op på de mest overraskende steder.

- Samle idéerne og generere koncepter: Her bliver idéerne og koncepterne videreudviklet til egentlige produktforslag med hjælp fra lead userne.

- Teste koncepterne: De nye produktkoncepter skal testes med den målgruppe, de er beregnet til.

3M havde 4-6 medarbejdere på projektet, som tog fem måneder. Medarbejderne brugte dog kun $35 \%$ af arbejdstiden på projektet. Det var fase to, hvor lead userne skulle identificeres, der tog størstedelen af tiden.

\section{Resultater}

Det var 3M's ledelse, der havde taget initiativet til den nye produktudviklingsmetode. Målet var at videreudvikle de nuværende kirurgiske operationsafdækninger, således at væksten på produktområdet kunne øges.

Som et resultat af ekspertinterviewene i fase II blev det konkluderet, at der i mange udviklingslande var et stort behov for et nyt produkt til forebyggelse af infektion ved operationer. Lægernes tiltro til at billige antibiotika ville kunne forebygge spredningen af infektion, holdt ikke i det lange løb. Denne trend var således kendetegnet ved, at der var et behov for at finde et billigere og mere effektivt produkt til at beskytte mod infektioner. Ud fra denne indsigt blev 3M's mål med projektet nu tilpasset det identificerede behov: "At finde en billigere og mere effektiv måde til at forebygge spredningen af infektion”. Løsningen skulle samtidig være billigere end 3M's nuværende operationsafdækning.

$3 \mathrm{M}$ fandt frem til lead userne ved hjælp af netværkskontakt. Denne proces foregik ved, at 3M først kontaktede deres nuværende kunder, som henviste til andre personer, der til sidst kunne lede frem til de rette lead usere. Ud over at lead userne dukkede op vidt forskellige steder, så var de samtidig også meget forskellige personer. Eksempelvis fandt man ud 
af, at nogle af specialisterne inden for dyrlægehospitalerne havde stor erfaring med at holde infektionsniveauet nede, på trods af at der her var store omkostningsbegrænsninger. En anden overraskende lead user blev fundet $\mathrm{i}$ et makeupstudie i Hollywood. Makeup artisten havde stor erfaring med at påføre materiale på hud, således at det var let at fjerne igen og samtidig ikke irriterede huden. 3M interviewede desuden læger i Bosnien, som kæmpede med infektionerne under ekstreme krigsforhold. Dette var meget vigtige oplysninger i designet af infektionsmaterialet.

Ud fra den sidste fase af lead user processen, hvor der blev afholdt en workshop for lead userne, blev der genereret idéer og koncepter til 6 nye produktlinier.

Anvendelsen

Af de seks produktlinier, der fremkom ved den afsluttende workshop, blev de tre, som man mente, der var de største muligheder i, præsenteret for 3M's ledelse. Disse tre produktlinier var: En økonomibesparende linie af kirurgisk operationsafdækning, håndholdt udstyr til brug af hudeksperter og en ny linie af produkter, der ved hjælp af antimikrobiel beskyttelse dækker det udstyr, der bruges i operationer, således at der ikke opstår infektioner.

Havde 3M ikke kigget udover sine traditionelle kunder, de almindelige hospitalslæger, var produktudviklingsafdelingen aldrig kommet frem til så innovative produktudviklinger.

\section{Evaluering}

3M har haft stor succes med at anvende lead user metoden til produktudvikling. Specielt den økonomibesparende linie af kirurgisk operationsafdækning blev en stor succes for 3M. I figur 12 ses et eksempel på den økonomibesparende linie af kirurgisk operationsafdækning.
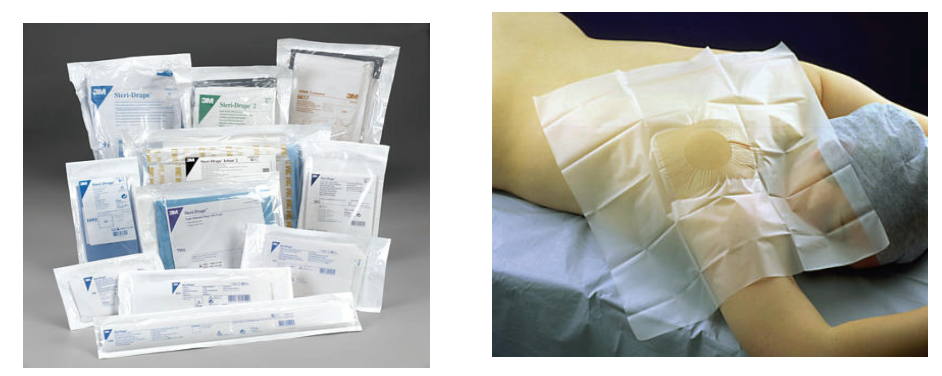

Figur 12: Eksempel på den økonomibesparende linie af kirurgisk perationsafdcekning

Ud over at 3M har anvendt lead user metoden til at udvikle nogle succesfulde produkter, har introduktionen af metoden også haft andre positive effekter på produktudviklingsprocessen. Metoden bragte repræsentanter fra de forskellige afdelinger sammen i teams, som arbejdede tæt sammen med lead users på forskellige områder; denne form for tværgående samarbejde er kendt for at være en succesfaktor i produktudviklingsprocesser. 
I dag har 3M brugt lead user metoden på flere forskellige produktområder, og der er i ledelsen stadig stor entusiasme for metoden.

Selv om casen er fra det industrielle marked, er det ikke svært at forstille sig lignende anvendelser på konsumentvaremarkeder. Nøglerne til en succesfuld anvendelse af metoden er identificeringen af lead users og den senere test med den nye målgruppe, som tit jo ikke er identisk med lead userne.

\subsection{Courtyard by Marriott}

Udvikling af et nyt hotelkoncept gennem conjoint analyse. ${ }^{5}$

Virksomhedsbeskrivelse

The Marriott Corporation har 2.600 hoteller placeret rundt om i USA og i 70 andre lande. The Marriott Corporation har eksisteret siden 1927, men det var først i 1957, at Marriott gik ind i hotelbranchen og åbnede det første hotel i USA. Marriott har hoteller under 16 forskellige brands. Hotelkæden Courtyard by Marriott er et af disse brands. Courtyard by Marriott er et koncept, der blev udviklet i starten af 1980'erne ved hjælp af den såkaldte conjoint analyse, som er et redskab til at kvantificere brugerønsker og anvende dem $i$ et produktudviklingsforløb.

Marriott har hovedkontor i Washington, D.C., og der er i alt cirka 128.000 medarbejdere. I 2004 havde Marriott en samlet omsætning på 10 milliarder \$. Marriott er af Fortune Magazine kåret som den mest beundringsværdige organisation i udlejningsbranchen og som en af de bedste arbejdspladser.

Problemstilling

I starten af 80 'erne satte Marriott en undersøgelse i gang for at vurdere, om der var nogle kundesegmenter, der ikke blev tilfredsstillet tilstrækkeligt med det daværende udbud af hoteller. Den indledende analyse identificerede to segmenter, der ikke var tilfredse med det daværende hoteludbud: forretningsrejsende, der rejste mindst seks gange om året og boede på middelklassehoteller, og turister, der rejste mindst 2 gange om året. Et kritisk spørgsmål var herefter: Hvilken kombination af hotelfaciliteter skulle Marriott designe og tilbyde for at tiltrække disse potentielle kunder? Nogle af de konkrete spørgsmål, som Marriott ønskede at få svar på gennem den videre analyse, var blandt andet:

1. Hvordan skal de nye hoteller positioneres?

2. Hvilke faciliteter og services skal tilbydes?

3. Hvad skal prisstrategien være?

\footnotetext{
${ }^{5}$ Casen bygger hovedsagelig på Wind et al., 1989
} 
4. Hvordan vil de to identificerede segmenter tage imod det nye hoteltilbud?

Metode

Marriott valgte at anvende den såkaldte hybrid conjoint analyse til at besvare ovenstående spørgsmål. Analysen blev gennemført med en stikprøve på i alt 601 potentielle brugere.

En conjointanalyse er en analyse, der kan belyse produktegenskabers (attributters) relative betydning for kundernes samlede tilfredshed med den modtagne ydelse. Respondenten skal bedømme eller vælge mellem forskellige hypotetiske produkter, hvor hvert produkt er beskrevet gennem en række attributter, afledt af et større bagvedliggende design. Ud fra bedømmelserne kan der gennem anvendelse af statistiske redskaber afledes mål for den relative vigtighed af en attribut i forhold til en anden, samt for hvordan de forskellige attributniveauer bidrager til den overordnede præference for produktet. I denne case kan attributterne eksempelvis være roomservice, motionscenter, sauna eller værelsesstørrelse. Ved hjælp af conjoint analysen kan man finde frem til, hvordan forbrugeren "trader off" mellem de forskellige attributter, samt hvilke attributniveauer der foretrækkes.

Hybrid conjoint modellen blev udviklet i starten af 1980'erne. Hensigten med modellen var at reducere kompleksiteten af den traditionelle conjoint analyses dataindsamling. Metoden er især velegnet, hvis antallet af attributter er stort. Hybrid conjoint modellen beregner nytteværdien af alle attributter af alle niveauer, mens omfanget af respondentens opgaver bliver minimeret.

Hybrid conjoint modellen er således en version af den almindelige conjoint analyse og består af to trin. Det forste trin er vægtning af alle attributniveauer og hver enkelt attribut. Respondenten bliver vist et antal attributter med forskellige niveauer. Respondenten skal herefter vurdere hvert attributniveau på $\mathrm{fx}$ en 10 point skala og give det mest ønskede attributniveau 10. Efter at have vurderet alle sæt af attributniveauer skal respondenten vurdere den relative betydning af hver attribut. Det andet trin er den traditionelle rating af en række hypotetiske produktbeskrivelser. Her vises respondenten et begrænset ( 8 eller 9 ) sæt af produktbeskrivelser, som herefter skal vurderes på en numerisk skala.

Conjoint analysen hos Marriott foregik ved, at hver af de 601 respondenter blev tildelt 7 kort - et ad gangen. Disse kort indeholdt forskellige sæt af attributter omkring hotelfaciliteter. I tabel 6 ses den fuldstændige liste af attributterne. På hvert kort var der listet et sæt attributter med de dertil hørende attributniveauer. Figur 13 er et eksempel på det kort, der blev brugt i forbindelse med "rooms". Til hver attribut skulle respondenten tage stilling til, hvilket niveau der bedst passede til det hotel, de almindeligvis boede på, hvilket niveau var helt uacceptabelt for dem, og 
hvilket niveau de ønskede og var villige til at betale for. Herudover skulle respondenterne prioritere de forskellige attributter i forhold til hinanden.

Til sidst blev respondenterne forevist i alt 50 kort, 5 ad gangen, med komplette hoteltilbud (Figur 14). Hvert kort var således et nyt hotelkoncept. Respondenten skulle for hvert sæt af 5 hotelkoncepter vælge, hvad der var det mest attraktive tilbud for ham/hende. 
Tabel 6: De 50 attributter og dertil hørende attributniveauer

\section{EXTERNAL FACTORS}

Building Shape

L-shaped w/landscape

Outdoor courtyard

Landscaping

Minimal

Moderate

Elaborate

Pool type

No pool

Rectangular shape

Free form shape

Indoor/outdoor

Pool location

In courtyard

Not in courtyard

Corridor/View

Outside access/restricted view

Enclosed access/unrestricted

view/balcony or window

Hotel size

Small (125 rooms, 2 storeys)

Large (600 rooms, 12 storeys)

\section{ROOMS}

Entertainmen

Color TV

Color TV $\mathrm{w} / \mathrm{movies}$ at $\$ 5$

Color TV w/30 channel cable

Color TV w/HBO, movies etc.

Color TV w/free movies

Entertainment/Rental None

Rental Cassettes/in-room

Atari.

Rental Cassettes/stereo cas-

sette playing in-room

Rental Movies/ in-room

BetaMax

Size

Small (standard)

Slightly larger (1 foot)

Much larger (2 $1 / 2$ feet $)$

Small suite (2 rooms)

Large suite (2 rooms)

Quality of Décor

Budget motel décor

Old Holliday Inn décor

New Holliday Inn decor

New Hilton décor

New Hyatt décor

Heating and Cooling

Wall unit/full control

Wall unit/soundproof/ full

control

Central $\mathrm{H}$ or $\mathrm{C}$ (seasonal)

Central $\mathrm{H}$ or $\mathrm{C} /$ full control

Size of bath

Standard both

Slightly larger/sink separate

Larger bath, larger tub

Very large/tub for 2
Sink location

In bath only

In separate area

In bath and separate

Bathroom features

None

Shower Massage

Whirlpool (Jacuzzi)

Steam bath

Amenities

Small bar soap

Large soap/shampoo/shoeshine

Large soap/bath gel/shower cap/sewing kit

\section{FOOD}

Restaurant in hotel

None (coffee shop next door)

Restaurant/lounge combo

\section{limited menu}

Coffee shop, full menu

Full-service restaurant, full menu

Coffee shop/full menu and

good restaurant

Restaurant nearby

None

Coffee shop

Fast food

Fast food or coffee shop and

moderate restaurant

Fast food or coffee shop and

good restaurant

Free continenta

None

Continental included in room

rate

Room service

None

Phone-in order/guest to pick

up

Room service, limited

menu

Room service, full menu Store

No food in store

Snack items

Snack, refrigerated items,

wine, beer, liquor

Above items and gourmet

food items

Vending service

None

Soft drink machine only

Soft drink and snack machines

Soft drink, snack, and sand-

wich machines

Above and micro oven avail-

able

In-room kitchen facilities

None

Coffee maker only

Coffeemaker and refrigerator

Cooking facilities in room
LOUNGE

Atmosphere

Quiet bar/lounge

Lively, popular bar/lounge

Type of people

Hotel guests and friends

Open to public-general

appeal

Open to public - many singles

Lounge nearby

None

Lounge/bar nearby

Lounge/bar w/entertainment nearby

\section{SERVICES}

Reservations

Call hotel directly

800 reservation number

Check-in

Standard

Pre-credit clearance

Machine in lobby

Check-out

At front desk

Bill under door/leave key

Key to front desk/bill by mail

Machine in lobby

Limo to airport

None

Yes

Bellman

None

Yes

Message service

Note at front desk

Light on phone

Light on phone and message

under door

Recorded message

Cleanliness/upkeep/

management skill

Budget motor leve

Holiday Inn level

Nonconvention Hyatt level

Fine hotel level

Laundry/valet

None

Client drop off and pick up Self-service

Valet pick up and drop off

Special Services (Concierge)

None

Information on restaurants,

theatres etc.

Arrangements and reservations

Travel problem solution

Secretarial services

None

Xerox machine

Xerox machine and typist

Car maintenance

None

Take car to service

Gas on premises/bill to room
Car rental, Airline reservations

None

Car rental facility

Airline reservations

Car rental and airline reservations

LEISURE

Sauna

None

Yes

Whirlpool/Jacuzzi

None

Outdoor

Indoor

Exercise room

None

Basic facilities w/weights

Facility w/nautilus equipment

Racquet ball courts

None

Yes

Tennis courts

$\underline{\text { None }}$

Yes

Game room/entertainment

None

Electric games/pinball

Electric games/pinball/ping

pong

Above + movie theatre, bowl-

ing

Children's playroom/ play-

ground

None

Playground only

Playroom only level

Playground and playroom

Pool extras

None

Pool w/slides

Pool w/slides and equipment

Pool w/slides, waterfall,

equipment

SECURITY

Security guard

None

11 a.m. to 7 p.m.

7 p.m. to 7 a.m.

Smoke detector

None

In rooms and hotel

Sprinkler system

None

Lobby and hallways only

Lobby/hallways/rooms

24-hour video camera

None

Parking/hallways/public areas

Alarm button

None

Button in rooms, rings desk 
Most Frequently " $\mathrm{X}$ " in the TRIANGLE in the block that comes closest to describing your current hotel (ONLY "X" ONE)

Used Hotel Chain "X" in the CIRCLE in the block(s) that you find to be completely unacceptable (YOU MAY "X" NONE, ONE OR MORE THAN ONE)

"X" in the SQUARE in the block that represents what you want and are willing to pay for (ONLY "X" ONE)

Figur 14: Beskrivelse af hypotetisk hotelkoncept

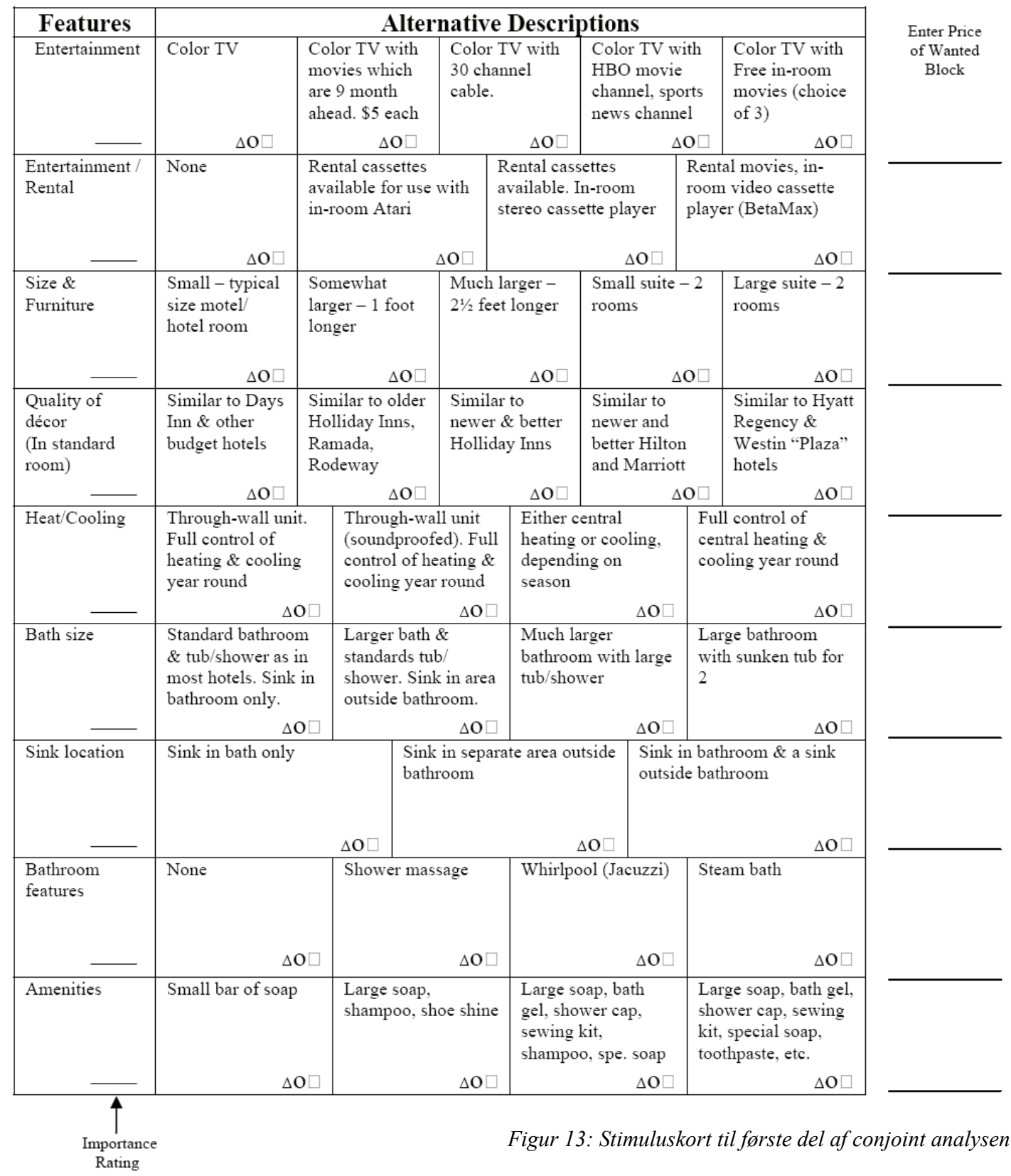




\section{ROOM PRICE PER NIGHT IS $\$ \underline{44.85}$}

BUILDING SIZE. BAR/LOUNGE

Large (600 rooms) 12-story hotel with:

- Quiet bar/lounge

- Enclosed central corridors and elevators

- All rooms have very large windows

LANDSCAPING/COURT

Building forms a spacious outdoor courtyard

- View from rooms of moderately landscaped courtyard with

- Many trees and shrubs

- The swimming pool plus a fountain

- Terraced areas for sunning, sitting, eating

FOOD

Small moderately priced lounge and restaurant for hotel guests/friends

- Limited breakfast with juices, fruit, Danish, cereal, bacon and eggs

- Lunch - soup and sandwiches only

- Evening meal - salad, soup, sandwiches, six hot entrees including steak

HOTEL/MOTEL ROOM QUALITY

Quality of room furnishings, carpet, etc. is similar to:

- Hyatt Regencies

- Westin "Plaza" Hotels

ROOM SIZE\& FUNCTION

Room 1 foot longer than typical hotel/motel room

- Space for comfortable sofa-bed and 2 chairs

- Large desk

- Coffee table

- Coffee maker and small refrigerator

SERVICE STANDARDS

Full service including:

- Rapid check in/check out systems

- Reliable message service

- Valet (laundry pick up/deliver)

- Bellman

- Someone (concierge) arranges reservations, tickets, and generally at no cost

- Cleanliness, upkeep, management similar to

- Hyatts

- Marriotts

LEISURE

- Combination indoor-outdoor pool

- Enclosed whirlpool (Jacuzzi)

- Well-equipped playroom/playground for kids

SECURITY

- Night guard on duty 7 p.m. to 7 a.m

- Fire/water sprinklers throughout hotel

$\mathrm{X}$ " the ONE box below which best describes how likely you are to stay in this hotel/motel at this price:

\begin{tabular}{|c|c|c|c|c|}
\hline $\begin{array}{c}\text { Would stay } \\
\text { there almost all } \\
\text { the time }\end{array}$ & $\begin{array}{c}\text { Would stay } \\
\text { there on a } \\
\text { regular basis }\end{array}$ & $\begin{array}{c}\text { Would stay } \\
\text { there now and } \\
\text { then }\end{array}$ & $\begin{array}{c}\text { Would rarely } \\
\text { stay there }\end{array}$ & $\begin{array}{c}\text { Would not stay } \\
\text { there }\end{array}$ \\
$\square$ & $\square$ & $\square$ & $\square$ & $\square$ \\
\hline
\end{tabular}




\section{Resultater}

Analysen viste, at mange forretningsrejsende og turister var utilfredse med det daværende udbud af hoteller. Nogle hoteller var for dyre og havde faciliteter, der ikke blev værdsat af den rejsende. Andre billigere hoteller havde for få faciliteter. Et hotel med rimelige priser og acceptable faciliteter manglede således på markedet. Ud fra dette blev følgende positionering foreslået: "Et lille anderledes hotel med rimelige priser". At dette var den rette positionering, blev understreget af, at begge segmenter foretrak hoteller, der var stille, uformelle, afslappende og med personlighed. De forretningsrejsende ønskede et stille og roligt sted, hvor de kunne opholde sig, når de ikke arbejdede. Samtidig var det vigtigt, at det var et billigt hotel, da de rejste meget. Turisterne ønskede et sted, hvor de kunne komme hen og slappe af, og for dem var prisen også af afgørende betydning.

Analysen forsynede Marriott med meget detaljerede retningslinier for, hvordan de skulle vælge de op til 200 forskellige faciliteter og services. Herudover blev Marriott også udstyret med klare idéer om:

- Hvordan de forskellige kunder fordelte sig på de forskellige hotelkoncepter, der blev forevist.

- Fra hvilke typer af hoteller dette nye hotel lokkede gæster.

- Hvordan man kunne karakterisere det segment, der tiltrækkes af en specifik kombination af faciliteter og services.

\section{Anvendelse}

Medarbejdere fra Marriotts forskellige produktudviklingsafdelinger var alle involveret i processen med at implementere resultaterne fra analysen over i det endelige produkt. Courtyard by Marriott, som blev resultatet af analysen, indeholdt stort set alle de forslag, der var kommet frem i undersøgelsen. De understregede attributter i tabel 6 viser, at alene ud fra det første sæt af attributter (eksterne faktorer) blev en gårdsplads, små værelser, lukkede centrale gange og trapper, firkantet pool, m.v. implementeret i det endelige hotel. Dette var attributter, som var prioriteret højt af respondenterne. Alle de faciliteter og services, der i dag tilbydes på hotellet, var blandt de, der blev vurderet højest af respondenterne. 

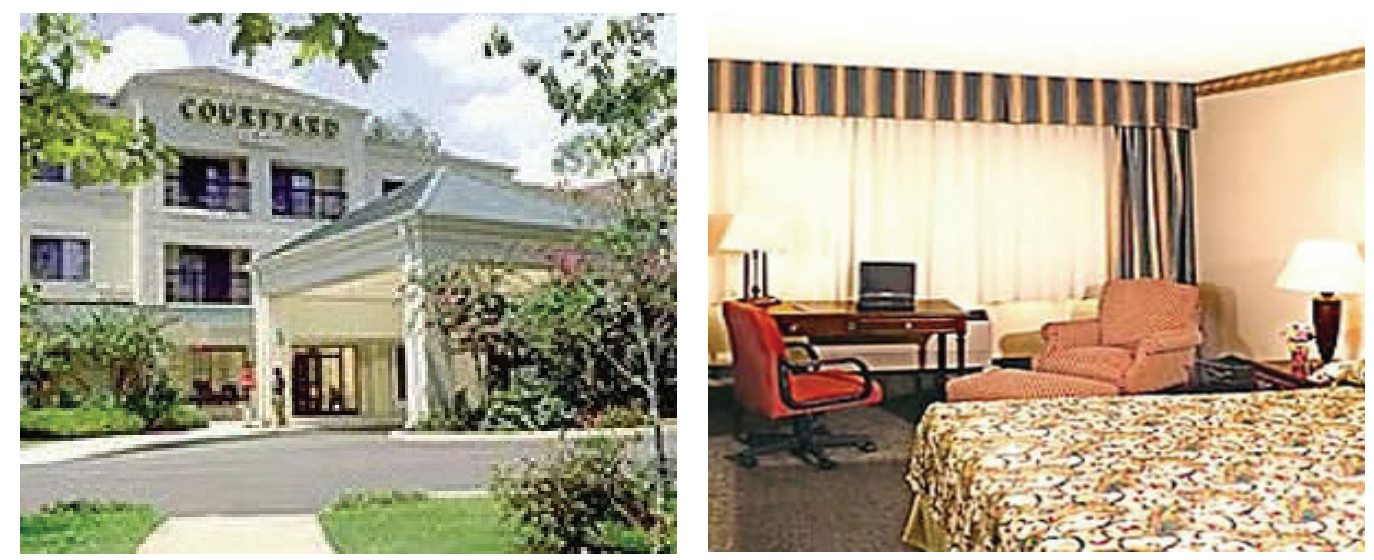

Figur 15: Courtyard by Marriott

Evaluering

Der er siden 1983 åbnet over 650 Courtyard by Marriott hoteller på verdensplan, hvor de 583 ligger i USA. De resterende hoteller er placeret i 21 andre lande verden over. Mellem 1983 og 1987 var Courtyard by Marriott den hurtigst voksende hotelkæde inden for mellem-prisklassen af hoteller. Marriott identificerede et gap i markedet, og valgte at lukke dette ved at designe Courtyard by Marriott. Ud over at Marriotts succes kom til udtryk gennem salgstal og antal hoteller verden over, kom det også til udtryk ved, at de øvrige hoteller i samme priskategori mistede markedsandele. Mange af de virksomheder, som følte sig truede, begyndte at efterligne Courtyard by Marriott på deres populære egenskaber. Samtidig blev hotelkonceptet i nogle tilfælde klonet af konkurrenterne.

The Marriott Corporation har efter udviklingen af Courtyard by Marriott udvidet brugen af conjointanalyse til at designe flere produkter til organisationens produktportefølje. Her kan blandt andet nævnes designet af time-share lejligheder samt udvikling af hotelkæderne Fairfield Inn og Marriott Suites.

Casen illustrerer anvendelsen af conjoint analysen på et forholdsvist komplekst produkt, og den illustrerer endvidere tydeligt både fordele og ulemper ved dette redskab til større forbrugerorientering. Det forudsætter nemlig, at problemstillingen er så meget præstruktureret, at alle relevante attributter og deres niveauer kan listes. Metoden tillader kun en optimering inden for dette sæt. Her får man til gengæld meget detaljerede oplysninger, der viser noget om, hvordan forbrugere prioriterer de forskellige aspekter ved produktet, og som dermed gør det muligt at bygge det ind $\mathrm{i}$ produktet, som forbrugerne sætter pris på og er villige til at betale for, og undlade det, som i forbrugernes øjne er mindre vigtigt. Det er dog klart, at metodens anvendelse kræver et forudgående kvalitativt arbejde for at sikre, at ingen (i forbrugernes øjne) vigtige attributter bliver overset. 


\subsection{Post Danmark}

Forbrugertilfredshedsmålinger og optimering af serviceydelsen. ${ }^{6}$

Virksomhedsbeskrivelse

Post Danmark er Danmarks nationale postvirksomhed. Virksomheden indsamler og distribuerer breve og pakker, omdeler adresseløse forsendelser samt tilbyder Facility Services og eKommunikationsløsninger. Post Danmark har fire forretningsenheder: Erhvervskunder, Privatkunder, Kurer Ekspres Pakker samt International Post.

Siden 2002 har Post Danmark været et aktieselskab med staten som hovedaktionær. Post Danmark har en årlig omsætning på 11 milliarder kr. og beskæftiger i alt ca. 22.000 fuldtidsmedarbejdere. Det er således er en af Danmarks største virksomheder.

På grund af øget konkurrence begyndte Post Danmark i 1998 at måle kundetilfredsheden ved hjælp af ECSI-analyser. Ud fra disse analyser fik ledelsen indblik i, på hvilke områder forbedringer var en nødvendighed, hvis kundetilfredsheden skulle øges. Resultater fra år 2000 og 2001 viser, at tilfredsheden med Post Danmarks produkter og serviceydelser har været stigende, efter at der er gennemført forbedringer på de områder, som kunderne var utilfredse med.

Problemstilling

Frem til 1995 havde Post Danmark eneret til postudbringning. I 1995 blev monopolet for postudbringning brudt, og Post Danmark opererer derfor i dag på et marked med gradvis liberalisering. Der forventes i de kommende år en endnu mere skærpet konkurrence på postmarkedet, idet der ifølge et EU-direktiv er truffet beslutning om, at alle medlemslande skal arbejde sig hen imod en fuld liberalisering på postmarkedet fra og med år 2009. Denne beslutning har store konsekvenser for Post Danmark, der i dag har eneret på nationale breve op til 50 gram.

Ud over den skærpede konkurrence på postmarkedet har der i de senere år været et markant afsætningsfald på brevmarkedet, hvilket forventes at fortsætte de kommende $a^{7}{ }^{7}$. En af hovedårsagerne til denne udvikling er de substituerende produkters indtræden på markedet. Udbredelsen af elektronisk kommunikation, der både er billigere og hurtigere, er en kommunikationsform, som en stor del af befolkningen sætter pris på og benytter sig af.

Denne øgede konkurrence på postmarkedet har medført, at Post Danmark i de senere år har haft stor fokus på kundetilfredshed og -loyalitet. I 1998 påbegyndte Post Danmark derfor kundetilfredshedsanalyser med det

\footnotetext{
${ }^{6}$ Udarbejdet på baggrund af interview med markeds- og analysechef i Post Danmark, Peter Hatlö.

${ }^{7} \mathrm{http} / / /$ www.postdanmark.dk/cms/da-dk/files/Bestyrelsensberetning_2004.pdf
} 
formål at skabe mere loyale kunder. Kundetilfredshedsanalyserne bliver både foretaget blandt Post Danmarks privatkunder og erhvervskunder.

\section{Metode}

European Customer Satisfaction Index (ECSI) er et værktøj, der kan give virksomheden et bedre grundlag for at tage beslutninger om markedsføringsstrategien. Med dette værktøj kan virksomheden få indblik i, hvilke faktorer der har størst betydning for kundetilfredsheden og -loyaliteten. Er det forbedringer af image, forventninger, produktkvalitet eller kundebetjeningen, virksomheden skal fokusere på? Når vi i denne rapport især koncentrerer os om produktudvikling, er det vigtigt at have for øje, at ECSI-analysen kan give indblik i, præcis hvilke af virksomhedens produkter der trænger til forbedringer.

Post Danmark måler kundetilfredsheden blandt et repræsentativt udsnit af erhvervskunder og privatkunder. Disse er enten telefonisk eller per brev blevet interviewet om deres holdning til Post Danmark. Herunder er ECSI-modellen for Post Danmarks Privatkunder illustreret.

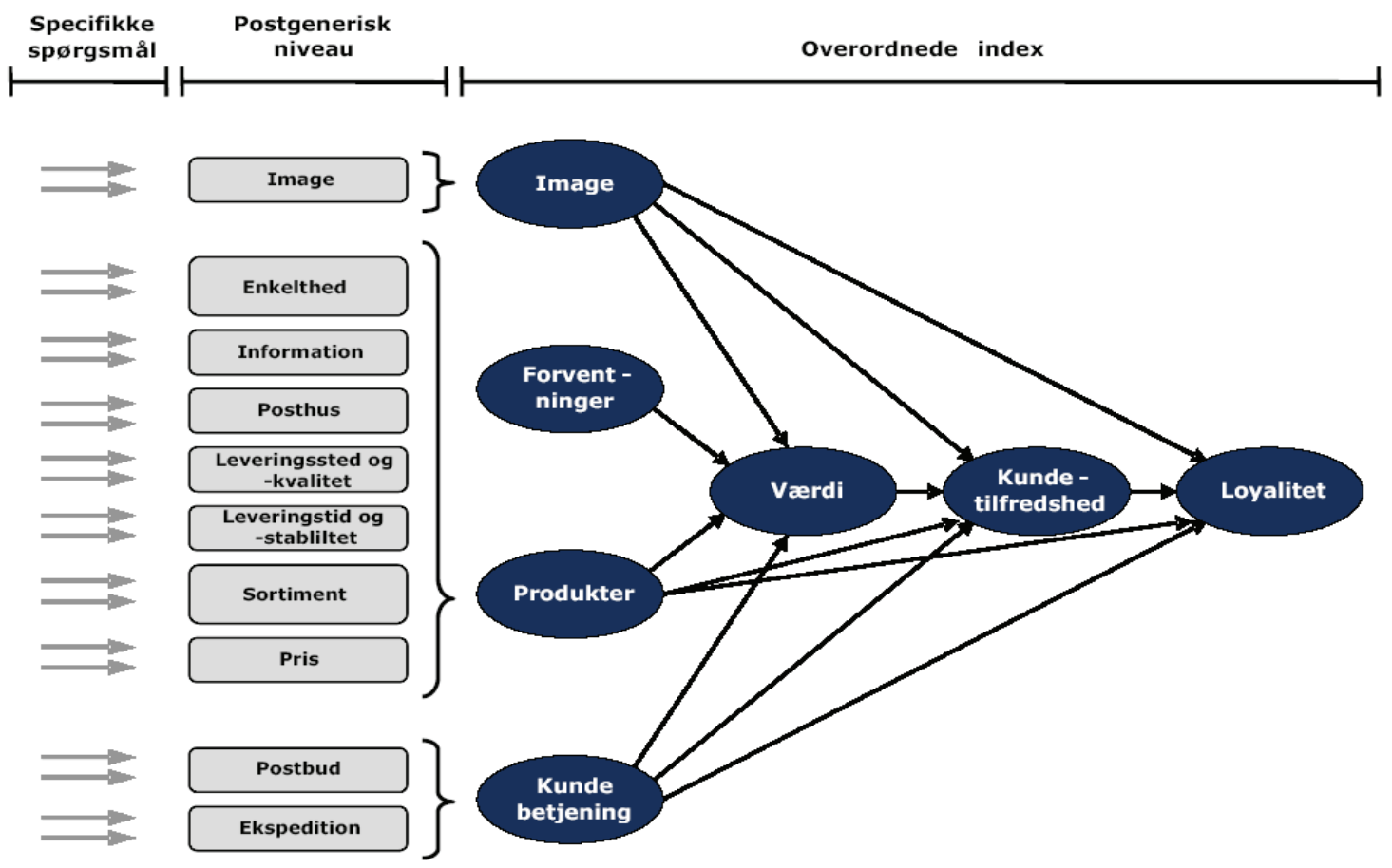

Figur 16: ECSI-modellen for Privatkunder

Kilde: Post Danmark

Post Danmark har udvidet Privatkunde-modellen med flere specifikke spørgsmål, som uddyber privatkundernes vurdering af image, produkter og serviceydelser samt kundebetjening. Ved at kombinere ECSImodellen med virksomhedsspecifikke spørgsmål kan kundetilfredshedsmålingen bruges både på det strategiske og det taktiske/operationelle 
plan. Relationerne i modellen gør det muligt at prioritere indsatsområder både overordnet, men også specifikt.

For at finde ud af hvor Post Danmark kan foretage forbedringer, plottes resultaterne af både de specifikke og de generiske spørgsmål ind i kvalitetskort. Kvalitetskort giver et overblik over vigtighed og tilfredshed med de områder, som spørgsmålene henviser til. Resultaterne inddeles i følgende fire kategorier: styrker, muligheder, svagheder og trusler. Det er de områder, der er kategoriseret under trusler, der skal prioriteres højest i forbedringsprocessen, idet det er områder, der er vigtige for forbrugerne, og som de er mindre tilfredse med.

Kundetilfredshedsanalysen er kun en problemidentificeringsanalyse, så for at få en dybere indsigt i, hvad Post Danmark helt konkret skal gøre for at øge kundetilfredsheden, suppleres kundetilfredshedsanalysen ofte med andre ad hoc-analyser. Dette gøres i tilfælde, hvor der internt i Post Danmark er usikkerhed om, hvordan det givne område forbedres. Her undersøges det, hvad der skal til, for at kunden bliver mere tilfreds. Det er forskelligt, hvilke analyser der anvendes til dette, men fokusgrupper er en af de metoder, der af og til bliver anvendt.

\section{Resultater}

Med hensyn til ECSI-modellen er det fortrinsvis "Produkter og serviceydelser", der er relevant i produktudviklingen. Derfor vil vi i det efterfølgende kun gå i dybden med dette parameter. Tilfredsheden med Post Danmarks "Produkter og serviceydelser" afdækkes ved en række af specifikke spørgsmål. For at få et overblik over svarene grupperes disse spørgsmål under de syv overordnede grupper, der er angivet i figur 16. Resultaterne af disse overordnede grupper kan som før nævnt illustreres i et kvalitetskort. Et eksempel på Post Danmarks kvalitetskort for produkter og tjenesteydelser i år 2000 er illustreret i figur 17.

Ud fra et kort som dette kan det ses, at det specielt er leveringssted og -kvalitet, som Post Danmark i 2000 skulle prioritere højt. Post Danmark kunne ud fra de specifikke spørgsmål om leveringssted og -kvalitet se, at det især var nedenstående fire områder, der krævede forbedring. 


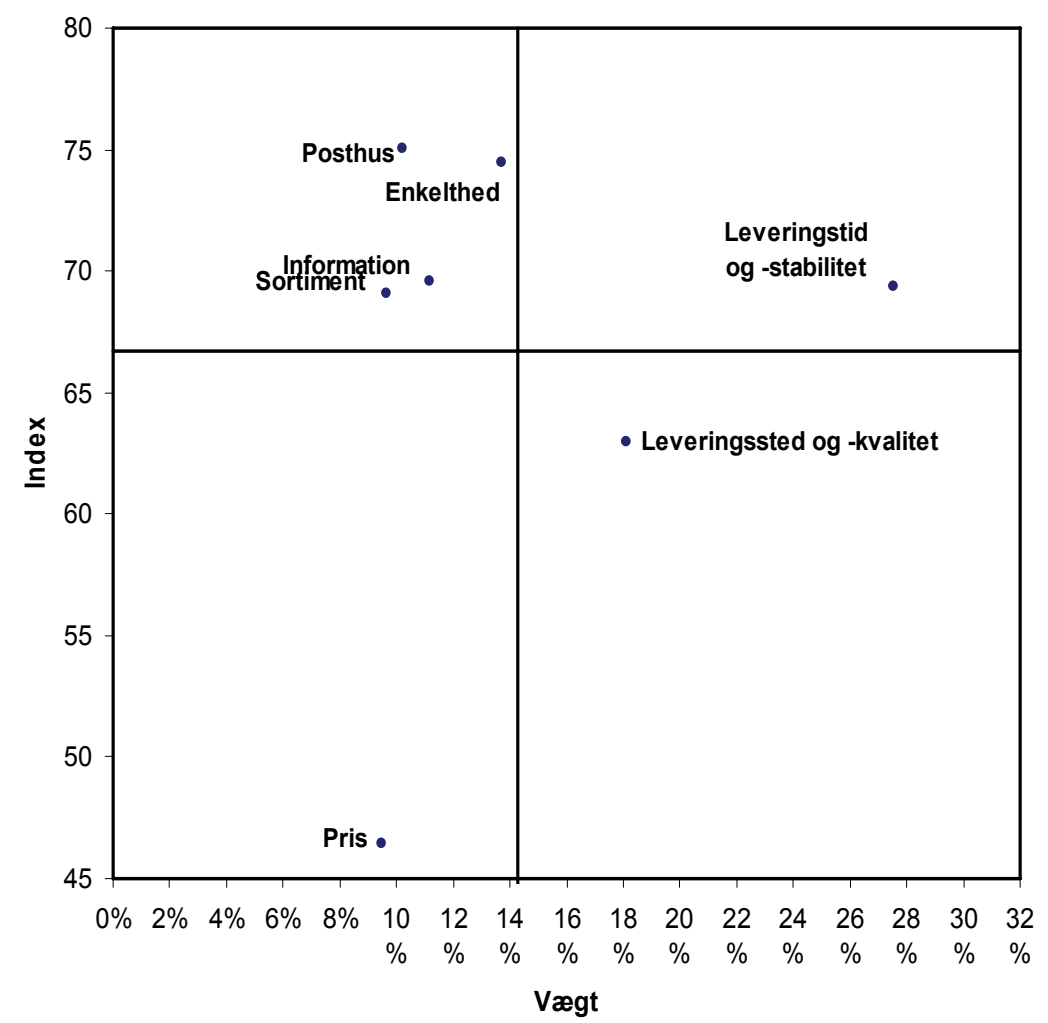

Tabel 7: Forbedringsområder ved leveringssted og -kvalitet

Forbedringsområder:

Breve leveres altid på rette adresse

Post Danmark reagerer hurtigt ved fejllevering af breve

Omadressering af post fungerer tilfredsstillende

Pakker leveres altid ubeskadiget

Kilde: Post Danmark

Efter en analyse som denne er Post Danmark i besiddelse af viden om kundernes vurdering af Post Danmarks produkter og serviceydelser, hvilket således kan anvendes i produktudviklingen.

Anvendelsen

På baggrund af resultaterne fra Post Danmarks kundetilfredshedsanalyser arbejdes der med at øge kundetilfredsheden. På udpegede områder laves indsatsplaner, som skal udmøntes i praksis. Post Danmark foretager på baggrund af analyserne dog ikke de store produktudviklinger, men mere løbende forbedringer af nuværende produkter og services. 
I 2000 udvalgte Post Danmark to af de ovenstående fire forbedringsområder som indsatsområder: "Breve leveres altid på rette adresse" og "Pakker leveres altid ubeskadiget". Årsagen til, at ikke alle forbedringsområder vælges som indsatsområde, kan formentlig henføres til, at produkter og serviceydelser overordnet set ikke er en trussel for Post Danmark. Måden, hvorpå Post Danmark forsøgte at forbedre de to områder, var gennem virksomhedens Gennemførelsesprogram. Gennemførelsesprogrammet introducerede Drejebogen, som bruges til at beskrive, hvordan en proces eller aktivitet skal udføres. Eksempelvis beskriver Drejebogen, hvordan omdeling af pakker og breve skal foregå ${ }^{8}$.

Ud over ovenstående eksempel på løbende forbedringer så har Post Danmark i årenes løb også foretaget forbedringer på en række andre områder. Kundetilfredshedsmålingerne har vist, at der blandt kunderne har været et ønske om en forbedring af posthusnettet. Her syntes kunderne eksempelvis, at posthusenes indretning var for rodet. Dette har medført nyudvikling af inventar - postreoler, skranker m.m. Herudover valgte Post Danmark at få færre, men bedre varer i posthusene ${ }^{9}$. På erhvervsmarkedet har Post Danmark fundet ud af, at der ønskes individuelle løsninger og bedre rådgivning. For at kunne lave flere og bedre individuelle løsninger er Post Danmark eksempelvis gået over til IP-telefoni, hvilket har gjort det muligt at agere mere fleksibelt overfor kunderne ${ }^{10}$. For at kunne tilbyde kunderne en bedre rådgivning, oprettede Post Danmark et uddannelsesforløb, der kunne geare medarbejderne til bedre at kunne rådgive især erhvervskunderne.

Evaluering

Post Danmark har været meget tilfredse med kundetilfredshedsanalyserne. Analyserne giver Post Danmark en god indsigt i, hvilke områder det er nødvendigt at foretage forbedringer på for at kunne opretholde en høj kundetilfredshed og dermed en høj kundeloyalitet.

Tabel 8: Resultatet af Post Danmarks forbedringstiltag i 2000

\begin{tabular}{lcc}
\hline & \multicolumn{2}{c}{ Index: } \\
Forbedringsområder: & år 2000 & år 2001 \\
\hline Breve leveres altid på rette adresse & 50 & 59 \\
Pakker leveres altid ubeskadiget & 66 & 76 \\
\hline
\end{tabular}

Kilde: Post Danmark

For at vurdere hvorvidt kundetilfredshedsanalyserne har haft en egentlig effekt, kan man se på, hvordan tilfredshedsindeksene på de forskellige

\footnotetext{
${ }^{8}$ http://www.postdanmark.dk/cms/da-dk/files/Ansoegningsdokument_5.pdf

http://www.postdanmark.dk/iis/nyheder/vis_nyhed.asp?ID=144\&NyhedType=generelle \&vis=arkiv\& usr $=\&$ year $=2000$

${ }^{10}$ www.netdesign.dk/pdf/netnews.10.05_web.pdf
} 
indsatsområder har udviklet sig fra år til år. I nedenstående tabel ses udviklingen i tilfredshedsindeksene på de to områder, som Post Danmark i år 2000 valgte at forbedre.

Stigningerne på ovenstående to områder demonstrerer, at de tiltag, som Post Danmark iværksatte i år 2000, og de tiltag som de enkelte postområder har iværksat, har haft den ønskede effekt. Tilfredshedsindeksene er steget med henholdsvis $18 \%$ og $15 \%$.

Samtidig med kundetilfredshedsanalyserne har det dog været nødvendigt for Post Danmark at foretage effektiviseringer i processerne for distributionen af brevforsendelser, og via avanceret produktionsudstyr er processerne i høj grad automatiseret ${ }^{11}$. Disse effektiviseringer har blandt andet medført introduktionsproblemer med de nye maskiner samt en del afskedigelser blandt Post Danmarks personale ${ }^{12}$, hvilket har trukket virksomhedens overordnede kundetilfredshedsindeks i nedadgående retning. Dette indikerer, at effekten af Post Danmarks forbedringstiltag formodentlig er større end det tallene i tabel 8 antyder.

\subsection{Dean Foods}

Etablering af en consumer affairs afdeling. ${ }^{13}$

Virksomhedsbeskrivelse

Dean Foods er et amerikansk mejeriselskab, der forarbejder og distribuerer mælk samt andre mejeriprodukter. Produktsortimentet spænder fra mælk, is og oste til vand samt forskellige slags juices. Med sine cirka 8 milliarder \$ i omsætning er selskabet et af de største mejeriselskaber i verden, kun overgået af den schweiziske mejerigigant Nestlé.

Dean Foods, der har hovedsæde i Dallas, har eksisteret siden 1925, hvor det første mælkeanlæg blev købt. Mælken bliver behandlet i cirka 110 fabrikker, der er placeret i USA, Spanien, Portugal og England. Dean Foods har ansat mere end 26.000 personer til produktionen af produkterne.

På grund af manglende forbrugerorientering påbegyndte Dean Foods i 1995 søgningen efter et service bureau, der kunne hjælpe selskabet med at få implementeret en consumer affairs afdeling. En sådan afdeling ville kunne give Dean Foods de oplysninger om forbrugerne, som produktudviklingsteamet manglede for at kunne udvikle produkter, der levede op til forbrugernes behov og forventninger.

\footnotetext{
${ }^{11} \mathrm{http} / / / \mathrm{www}$.postdanmark.dk/cms/da-dk/files/Formandens_beretning_gen.fors.2003.pdf

${ }^{12} \mathrm{http}: / /$ www.apk2000.dk/netavisen/artikler/arbejdsplads/2002-na1230_postdk_fyrer.htm

${ }^{13}$ Hovedsageligt baseret på http://valueofx.telerx.com/pages/pdf/telerx_dean.pdf.
} 
Problemstilling

Før 1995 havde Dean Foods ingen consumer affairs afdeling. På langt de fleste produkter var der ingen henvisning til servicenumre, som forbrugeren kunne ringe til, hvis de havde spørgsmål om produktet eller eventuelle klager. På de produkter, hvor der trods alt var en henvisning til et nummer, var det til de lokale produktionsfabrikker. Ved en så decentraliseret kundeservice var det umuligt for Dean Foods at anvende oplysningerne systematisk til at forbedre forbrugerorienteringen. I Dean Foods var der således en mangel på forbrugeroplysninger, idet man ikke formåede at indsamle og analysere de data, der kunne opnås gennem interaktion med kunderne.

Det der igangsatte Dean Foods' fokusering på at få implementeret en central consumer affairs afdeling var, at selskabet var ved at planlægge en markedsekspansion gennem erhvervelsen af yderligere mejerier. Ledelsen indså, at den nuværende decentrale kundeservice ikke var tilstrækkelig ensrettet og dermed ikke god nok til, at der kunne opnås succes på dette udvidede marked. Da Dean Foods' ledelse blev klar over de oplysninger, der kunne opnås gennem kundeinteraktion og kundefeedback, besluttede ledelsen sig således for, at der skulle implementeres en consumer affairs afdeling.

Metode

En consumer affairs afdeling er en afdeling, der tager sig af kundehenvendelser. Disse henvendelser fra kunderne skyldes ofte, at kunderne ringer ind angående klager, vejledning eller forbedringsforslag til de produkter, som producenten har på markedet.

Den primære hensigt med at implementere en consumer affairs afdeling er, at afdelingen kan bidrage med informationer til markedsplanlægningen, produktudviklingen og kvalitetsforbedringer. Således er målet med en consumer affairs afdeling at opdage og udnytte mulighederne på markedet, opbygge strategisk viden og opnå viden om, hvilke produkter der er behov for i fremtiden.

Dean Foods' ledelse vurderede, at selskabet ikke selv havde kompetencerne til at få implementeret consumer affairs afdelingen på den bedst mulige måde. På baggrund af dette valgte Dean Foods at kontakte Telerx. Telerx er et servicebureau, der hjælper virksomheder med at implementere consumer affairs initiativer. Dean Foods valgte at indgå i et partnerskab med Telerx omkring consumer affairs afdelingen. Dette partnerskab betød, at Dean Foods kunne koncentrere sig som sine kernekompetencer, men samtidig få større indsigt i forbrugeroplysninger.

Halvdelen af medarbejderne i den nye consumer affairs afdeling i Dean Foods blev rekrutteret fra andre afdelinger i virksomheden for at opnå en blanding af medarbejdere med indsigt i produkterne og medarbejdere med indsigt $\mathrm{i}$ håndtering af forbrugerhenvendelser. Alle skulle gennem 5-7 ugers intensiv træning omkring produkter, procedurer og 
brugen af det nye informationssystem til kundehenvendelser. Der blev udarbejdet et standardiseret sæt af kundevenlige politikker og procedurer med en dertil hørende online manual. Denne manual udarbejdede Dean Foods sammen med Telerx. Ud over at manualen indeholdt informationer om politikker og procedurer, indeholdt den også oplysninger omkring alle virksomhedens produkter med hensyn til ingredienser og emballage.

Resultater

Etableringen af consumer affairs afdelingen medførte, at al kundekontakt, uanset om det var i form af telefonisk henvendelse, brevpost, e-mail eller fax, blev indtastet i det dertil oprettede kundekontaktsystem. Disse henvendelser gav Dean Foods adskillige oplysninger om forbrugerpræferencer, trends, potentielle muligheder og eventuelle kvalitetsproblemer.

Det rapporteringssystem, som Dean Foods nu var i besiddelse af, gjorde det også muligt at spore helt specifikke produktdata. Eksempelvis kunne consumer affairs teamet opspore alle kvalitetsproblemer, der havde at gøre med selskabets innovative dunkebeholdere. Det var herudover muligt at trække oplysninger frem angående de 10 hyppigst opståede bekymringer, som kunderne havde omkring dunkebeholderne i det første år, hvor produkterne var på markedet.

Tabel 9: Produktforbedringer på baggrund af kundehenvendelser

\begin{tabular}{|l|l|}
\hline Produktforbedring: & Baggrund for kundehenvendelse: \\
\hline $\begin{array}{l}\text { Tilføjelse på emballage om, } \\
\text { hvordan flasken åbnes. }\end{array}$ & $\begin{array}{l}\text { Consumer affairs afdelingen fik så mange henvendelser omkring problemer med at } \\
\text { åbne flasken, at marketingafdelingen valgte at tilføje ordet "Twist Off" på alle flasker. } \\
\text { Dette medførte at antallet af kundehenvendelser blev stærkt reduceret. }\end{array}$ \\
\hline $\begin{array}{l}\text { Tydeliggørelse af holdbar- } \\
\text { heden på ultra- } \\
\text { pasteuriserede produkter }\end{array}$ & $\begin{array}{l}\text { Consumer affairs afdelingen fandt ud af, at mange kunder ikke vidste, at ultra- } \\
\text { pasteuriserede produkter, i uåbnet stand, havde en længere holdbarhed end alminde- } \\
\text { lige produkter. Det var dog vigtigt, at produktet blev konsumeret inden for kort tid efter, } \\
\text { at det var åbnet. Consumer affairs afdelingen havde mange klager over, at produktet } \\
\text { ikke holdt indtil sidste anvendelsesdato. På grund af denne tilbagemelding tilføjede } \\
\text { Dean Foods bemærkningen "Once opened consume within seven days" på produktet. } \\
\text { Denne lille information gjorde, at der kom langt færre klager. }\end{array}$ \\
\hline $\begin{array}{l}\text { ÆEndring af farven på et } \\
\text { produkt. }\end{array}$ & $\begin{array}{l}\text { Mange kunder kontaktede Dean Foods' consumer affairs afdeling på grund af, at de } \\
\text { undrede sig over, hvorfor mælk med jordbærsmag var hvid i stedet for pink. Det viste } \\
\text { sig, at den pink farve forsvandt på grund af kombinationen af pasteurisering og den } \\
\text { lange holdbarhedsperiode. På baggrund af dette ændrede Dean Foods den type af } \\
\text { farve, der blev brugt, således at problemet blev løst. }\end{array}$ \\
\hline
\end{tabular}

Anvendelsen

Dean Foods har implementeret adskillige forbedringer på baggrund af data fra consumer affairs afdelingen. Forbedringerne har primært været $\mathrm{i}$ form af ændrede tiltag omkring emballageelementer. Tabel 9 viser en række eksempler på sådanne forbedringer.

Ovenstående produktforbedringer er kun eksempler på de mange forbedringer, der er sket på baggrund af kundehenvendelser. Forbedringerne har medført store fald i antallet af klager. I den første produktforbedring i tabel 9, skete der efter tilføjelsen "Twist Off" et fald på 78 \% i antallet af klager. 
Evaluering

Dean Foods' realisering af consumer affairs afdelingen har i mange tilfælde medført en øjeblikkelig feedback fra kunderne. Consumer affairs afdelingen har fået mulighed for at være blandt de første, der får at vide, hvad kunderne tænker om nye produkter. Ud over at indsamle og systematisere disse kundehenvendelser har man i Dean Foods også formået at sprede disse informationer rundt til de relevante afdelinger, således at det har været muligt for produktudviklingsafdelingen at implementere forbedringsforslagene i produkterne.

Casen viser, at de produktforbedringer, der kommer ud af en systematisk analyse af uopfordrede kundehenvendelser, for det meste er marginale. Der er her tale om forbedringer på emballage, information, eller mindre aspekter ved selve produktet. Inden for denne kategori kan der dog være tale om detaljer, som var til stor irritation for forbrugerne.

Langt de fleste kundehenvendelser er klager. Klager fører oftere til henvendelser end gode idéer til nye produkter. Den kan overvejes, om denne tendens kan ændres ved specielle incitamenter til forbrugere, der kommer med positive forbedringsforslag, for eksempel gennem prøver, gratis produkter eller lodtrækning om priser. 



\section{Innovations- og forbrugerpolitik}

I denne sidste del af rapporten vil vi komme ind på nogle af de politiske aspekter omkring brugerdrevet innovation. Vi starter med at se på innovationspolitikken. Innovationspolitik findes som etableret eller ligefrem prioriteret politikområde $\mathrm{i}$ alle nordiske lande, men har indtil for nylig ikke haft ret meget fokus på den brugerdrevne del af innovation. Vi ser på de klassiske begrundelser for og redskaber inden for innovationspolitik og spørger så, om de kan overføres på forbrugerdrevet innovation.

Derefter følger vi en lignende fremgangsmåde med henblik på forbrugerpolitik. Vi tager udgangspunkt i de klassiske forbrugerpolitiske instrumenter og spørger, hvordan de påvirker innovation. Vi formulerer så endeligt en række forslag til, hvordan forbrugerpolitik kan støtte forbrugerdrevet innovation.

Som del af input til denne del af rapporten er der blevet gennemført en række ekspertinterviews i Danmark, Finland og Norge. ${ }^{14}$

\subsection{Innovationspolitik - begrundelse og instrumenter}

Den grundlæggende økonomiske begrundelse for, at den offentlige sektor blander sig i innovationsprocessen er, at innovationsniveauet ellers ville være lavere, end hvad der er samfundsgavnligt, eller sagt på anden måde, at markedskræfterne, når man overlader dem til sig selv, ville resultere $\mathrm{i}$ et suboptimalt innovationsniveau.

Der er mindst fire begrundelser for, hvorfor dette måtte være tilfældet (Jaumotte \& Pain, 2005; Nyholm \& Langkilde, 2003); fire begrundelser som hver især begrunder de klassiske instrumenter i innovationspolitikken. For det første kan innovation muligvis fremmes gennem viden af mere grundlagsskabende karakter, hvis kommercielle anvendelsesmuligheder kan være usikre, og hvor den nytte, som den enkelte virksomhed kan drage af det, ikke står mål med de omkostninger, frembringelsen af denne viden vil medføre. Dette er begrundelsen for, at der findes offentligt finansieret forskning, som frembringer ny viden, som så senere kan bruges i produktudviklingsprocesser i virksomhederne. Den mere grundlæggende forskning er prækompetitiv og skal derfor støttes med offentlige midler. Det gælder for eksempel grundlæggende forskning i nye tek-

\footnotetext{
${ }^{14}$ Listen over interviews findes i appendiks. Jeg takker Henriette Boel Nielsen for hendes store hjælp med gennemførelsen af interviewene.
} 
nologier som bioteknologi, nanoteknologi og it. Jo mere anvendelsesorienteret forskningen bliver, jo mere skal industrien selv bidrage - her har vi et bredt spektrum af samarbejds- og samfinansieringsformer mellem den grundlæggende og rent offentligt finansierede forskning på den ene side og den virksomhedsinterne forskning og udvikling på den anden side.

For det andet vil den samfundsmæssige nytte af innovation være større, hvis viden kan flyde frit derhen, hvor den vil gøre mest gavn, og hvis den potentielle modtager af ny viden har et beredskab, der tillader at kunne forstå og anvende denne viden. Dette er begrundelsen for politiske tiltag, der fremmer videnstransfer fra vidensproducerende til vidensanvendende aktører, og især tiltag der skal fremme samarbejde mellem forskningsinstitutioner (især universiteter) og potentielle brugere af forskningsresultater. Blandt sidstnævnte har man haft specielt meget fokus på små og mellemstore virksomheder, ud fra en antagelse om at de store selv kan finde ud af at knytte de nødvendige kontakter til forskningsinstitutionerne og desuden også allerede har det modtagerapparat, der skal til for at have gavn af denne type kontakter. Sådanne tiltag i innovationspolitikken beskrives tit under overskriften teknologitransfer, hvilket indikerer, at den type viden, man mest har i tankerne, er viden om nye teknologier, og at anvendelsen, man tænker på, er ibrugtagning af denne viden i produktionsvirksomheder.

For det tredje kan der være mangel på kvalificerede folk, der kan bære innovation både i forskningsinstitutioner og i virksomheder, hvilket afleder en offentlig opgave $i$ at uddanne sådanne folk. Endeligt kan der for det fjerde være problemer med at de private finansmarkeder ikke stiller tilstrækkeligt meget risikovillig kapital til rådighed som grundlag for de mere risikable former for innovation, hvilket kan imødegås gennem forskellige former for innovationsstøtte.

De klassiske instrumenter i innovationspolitikken er dermed:

- finansiering af offentlig forskning

- innovationsstøtte enten gennem direkte tilskud til innovation eller gennem tilvejebringelse af risikovillig kapital

- uddannelse af kvalificeret arbejdskraft

- tiltag der fremmer videnstransfer

- beskyttelse af intellektuelle rettigheder, fx gennem patenter

Alle disse fem instrumenter har traditionelt været rettet mod udvikling og anvendelse af ny teknologi. Vi kan derfor sige, at innovationspolitikken har været teknologiorienteret. Dette er ikke et dansk eller nordisk fænomen, men gælder alle OECD lande. I Danmark er brugerdrevet innovation dog kommet på den politiske dagsorden (fx Danmarks Erhvervsråd, 2005), og man kan rejse spørgsmålet, om begrundelserne for innovati- 
onspolitiske tiltag kan være de samme for forbrugerdrevet som for teknologiorienteret innovation, om de klassiske innovationspolitiske instrumenter kan bruges også her, hvordan de evt. skal tilpasses, og om der muligvis er behov for nye instrumenter.

\subsection{Teknologi- vs. forbrugerorienteret innovationspolitik}

At innovationspolitikken indtil nu for det meste har været teknologiorienteret kan skyldes, at man ikke har været opmærksom på de (for)brugerorienterede aspekter ved innovation. Det kan også skyldes, at man mener, at markedet er bedre til af sig selv at frembringe brugerdrevet end teknologidrevet innovation.

Det var faktisk et gennemgående træk i de gennemførte ekspertinterviews, at informanterne var tilbøjelige til at mene, at den kunderettede del af innovationen var op til virksomhederne. Når virksomhederne ikke er gode nok til at tolke forbrugernes ønsker og behov, så vil de blive straffet gennem manglende efterspørgsel, hvilket jo er et af grundprincipperne i en markedsøkonomi. Kan det dermed argumenteres, at de ovenfor nævnte begrundelser for de klassiske innovationspolitiske instrumenter kun gælder for teknologiorienteret innovation?

For det første kan det konstateres, at eventuelle problemer med at skaffe risikovillig kapital selvfølgelig gælder alle former for risikofyldt innovation, uanset hvor meget teknologi- eller brugerorienterede de måtte være, og at der derfor ikke er nogen argumenter for, hvorfor finansielle former for innovationsstøtte skal begrænses til innovation, hvor ny teknologi er involveret.

Det er ikke så entydigt med argumenterne om en eventuel mangel på kvalificeret arbejdskraft. De teknologiorienterede aspekter af innovation kræver åbenlyst andre kvalifikationer end de brugerorienterede. De teknologiorienterede aspekter kræver kvalifikationer, der erhverves gennem uddannelser inden for ingeniør- og naturvidenskaberne. De brugerorienterede aspekter kræver kvalifikationer inden for samfundsvidenskaberne. De eneste samfundsvidenskabelige uddannelser, hvor forbrugerbehov og -ønsker og deres betydning for innovation eksplicit bliver behandlet i dag, er marketing specialiseringerne inden for de erhvervsøkonomiske uddannelser, og vægten emnet får i disse uddannelser varierer meget fra sted til sted. Der er ikke umiddelbart noget der tyder på, at der er en overflod af kandidater med specialkompetencer inden for forbrugerdrevet innovation, og ønsket om flere uddannelsesforløb, der kan støtte denne kompetence, har da også været fremtrædende i Danmarks Erhvervsråds handlingsplan for brugerdrevet innovation.

Hvad så med frembringelse af mere grundlagsskabende viden? Kan man forvente, at virksomhederne selv er både motiverede og har evnen til 
at skaffe den viden om forbrugerbehov og -ønsker, som danner grundlag for forbrugerdrevet innovation?

Her kan man forvente, at mekanismerne, der bestemmer arbejdsdelingen mellem forskellige potentielle vidensproducenter, fungerer på samme vis som når det handler om produktion af teknologirelateret viden - både hvad angår motivationen og evnen. En virksomhed vil almindeligvis være motiveret til at prøve at forstå forbrugerønsker rettet mod deres egne produkter, og vil desuden ikke være motiveret til at dele disse oplysninger med andre, især ikke konkurrenterne. Mange virksomheder, specielt de mindre og mellemstore, vil dog måske ikke have evnen til selv at anvende nogle af de mere komplicerede redskaber omtalt i første hoveddel af denne rapport. De kan så outsource noget af opgaven til et markedsanalysebureau eller en konsulentvirksomhed med speciale i denne type redskaber, hvilket dog stadigvæk kræver, at virksomheden selv på kvalificeret vis har evnen til at indgå $i$ et samarbejde.

Når det handler om mere generel viden om $\mathrm{fx}$ forbrugertrends $\mathrm{i}$ den produktkategori, virksomheden arbejder inden for, så vil forholdet mellem omkostninger og forventet nytte for den enkelte virksomhed måske ikke opfattes sådan, at man vil investere i at fremskaffe denne viden. Produktion af denne type viden varetages dog ofte af markedet på den måde, at specialiserede virksomheder gennemfører branchestudier og sælger dem til de produktionsvirksomheder i branchen, der måtte være interesseret $i$ det.

Endelig er der produktionen af mere generel viden om, hvordan forbrugerbehov skabes, udvikler og forandrer sig - viden om de grundlæggende psykologiske, sociologiske og økonomiske processer, der påvirker de faktorer, der skaber værdiskabelse i forbrugernes bevidsthed. Denne form for grundlagsskabende viden er afgørende for forbrugerorienteret innovation, som jo netop ikke handler om at afdække de behov, der allerede eksisterer, men om at forstå de mekanismer, der medfører, at behovene opstår, og nyttiggøre dem i innovationsprocessen. Denne form for viden er ikke umiddelbart knyttet til enkelte innovationsprocesser, men skaber grundlag for de mere branche- og produktspecifikke analyser, og er dermed en opgave, som man med samme argumentation, som inden for teknologiudvikling, vil henvise til offentligt finansieret forskning. Det gælder også udviklingen af generiske instrumenter til at analysere forbrugerbehov og -ønsker, som dem der er omtalt i første hoveddel af denne rapport - disse er typisk udviklet i universitetsforskningsmiljøer og diffunderer derfra først til markedsanalyse- og konsulentvirksomheder og til sidst til produktionsvirksomheder.

Til sidst er der spørgsmålet om videnstransfer. Når det handler om teknologirelateret viden, er der åbenbart et erkendt behov for tiltag, der fremmer udveksling og anvendelse af den viden, der bliver produceret de forskellige steder. De væsentlige aktører, der skal dele viden, er forskningsinstitutioner og erhvervslivet, dvs. produktionsvirksomheder. Der 
findes i mange lande desuden særlige aktører, der skal være bindeled mellem forskningsinstitutioner og produktionsvirksomheder inden for teknologianvendelse, som fx GTS institutionerne i Danmark.

Gælder dette også forbrugerrelateret viden?

Der er ingen oplagt grund til at tro, at vidensdelingen mellem forskningsinstitutionerne og produktionsvirksomhederne fungerer bedre her. Der findes desuden almindeligvis ingen GTS-lignende institutioner, der hjælper med implementering og anvendelse af forbrugerrelateret viden, selv om SIFO i Norge og det nationale forbrugerforskningscenter i Finland er begyndt at bevæge sig lidt i denne retning. Til gengæld er der mange private mellemled $\mathrm{i}$ form af markedsanalysevirksomheder og innovationskonsulenter, der nogle gange har informationsudveksling både med forskningsinstitutioner og produktionsvirksomheder. Desuden er der både statslige og private organisationer med et forbrugerpolitisk sigte, der tit har ganske betydelig viden, der kan være relevant for at tolke forbrugerbehov, fx gennem håndteringen af forbrugerklager. Disse organisationer har for det meste ingen organiseret vidensdeling med den private sektor, ud over den som vedrører den konkrete klagebehandling. Hovedkonklusionen omkring videnstransfer er således, at behovet for tiltag der kan fremme vidensdeling om forbrugerforhold, er mindst lige så stor som behovet for tiltag, der kan fremme vidensdeling omkring teknologirelaterede forhold.

Hovedkonklusionen fra dette afsnit er, at de klassiske innovationspolitiske instrumenter (måske med undtagelse af patentbeskyttelse) er lige så relevante for forbrugerorienteret som for teknologidrevet innovation:

- finansiering af offentlig forskning omkring opståen, forandring og analyse af forbrugerbehov

- innovationsstøtte enten gennem direkte tilskud til innovation eller gennem tilvejebringelse af risikovillig kapital også til innovationsprojekter, som er forbrugerdrevet

- uddannelse af kvalificeret arbejdskraft, der har kompetencer i at analysere forbrugerbehov og omsætte denne viden $\mathrm{i}$ innovationsprocesser

- tiltag der fremmer videnstransfer om forbrugerrelaterede forhold, især mellem forskningsinstitutioner, markedsanalyse- eller konsulentvirksomheder, forbrugerpolitiske organisationer og produktionsvirksomheder

At sådanne tiltag kunne give den forbrugerdrevne innovation et løft til gavn for samfundet, kan aflæses i den meget høje fejlrate, der gælder for nye konsumentvarer, der bliver introduceret på markedet. Selv om de konkrete tal varierer afhængig af opgørelsesmetode og kriterier, så er det et kendt fænomen, at langt de fleste produkter, der søges introduceret på markedet, forsvinder igen efter kort tid. For eksempel er i Danmark kun 
$20 \%$ af nyintroducerede konsumentvarer stadigvæk på markedet efter et år (Martensen, 1993). Det tyder jo på, at den informationstransfer mellem forbrugere og virksomhederne, som ligger til grund for udviklingen af nye produkter, er mangelfuld, og at mange ressourcer bliver spildt $i$ innovationsprocesserne. Tiltag til fremme af forbrugerdrevet innovation vil derfor ikke nødvendigvis øge mængden af nye produkter, der kommer på markedet, men vil kunne resultere $\mathrm{i}$ at de produkter, der lanceres på markedet, er i bedre overensstemmelse med forbrugernes behov og ønsker.

\subsection{Forbrugerpolitik og innovation}

Også de klassiske forbrugerpolitiske instrumenter har innovationseffekter, selv om de traditionelt ikke har været i fokus.

En stor del af de klassiske forbrugerpolitiske instrumenter - forbrugerinformation, rådgivning, uddannelse, adgang til klagemuligheder - går ud på at forbedre forbrugernes muligheder for at opfylde deres rolle $\mathrm{i}$ en markedsøkonomi: at træffe købsbeslutninger der styrer allokeringen af ressourcerne. I den udstrækning det lykkes, at forbrugerne bliver bedre til at give udtryk for deres ønsker og behov gennem deres købsbeslutninger, vil det også medføre, at udbuddet af produkter bliver i bedre overensstemmelse med disse - fordi de i forbrugernes øjne 'dårlige' produkter vil forsvinde fra markedet hurtigere, og i forbrugernes øjne 'gode' produkter vil få øget efterspørgsel. Ved at styrke markedsmekanismen og ved at hjælpe forbrugerne med at opfylde deres rolle i markedet bliver udviklingen af nye produkter styret hen mod større hensyn til forbrugerne.

Ud over denne generelle - og svært kvantificerbare - effekt er der dog også mere specifikke effekter. Disse er et resultat af, at markedets aktører - både forbrugere og producenter - almindeligvis vil ændre adfærd, når der kommer nye markedssignaler. Når man giver forbrugerne mere information, fx gennem mærkningsordninger, gennem standardiseret produktinformation eller gennem tests af produkter, så er man nødt til at vælge de produktegenskaber, man vil informere om, og fravælge andre. Selv om målet måtte være at give forbrugerne generel kvalitetsinformation, så er man jo nødt til at definere, hvad kvalitet er, og få den operationaliseret gennem en række produktegenskaber. Det gælder især for sammenlignende produkttests.

Hvis forbrugerne bruger denne type information, kan det derfor medføre, at deres købsbeslutninger baseres på et lidt andet sæt af kriterier, end de ellers ville, og markedet, der reagerer på ændringerne i efterspørgselsmønstrene, vil reagere på det ved i videreudviklingen eller nyudviklingen af produkter at prioritere netop de kriterier, som også blev prioriteret $\mathrm{i}$ forbrugerinformationen. Effekten på producenternes produktudvikling kan faktisk indtræde, før forbrugerne overhovedet har reageret på informationen: når producenterne forventer, at informationer fra produkt- 
tests eller fra mærkningsordninger vil få indflydelse på forbrugerne, kan de komme ændringer i forbrugernes efterspørgsel i forkøbet og forbedre eller tilpasse produkterne tilsvarende. Sådanne effekter er blevet påvist fx i forbindelse med information udsendt af det tyske Stiftung Warentest (Raffee \& Silberer, 1984).

Når den anvendte kvalitetsdefinition i denne type information er rimelig bred, så kan den medføre en generel forøgelse af kvaliteten af produkterne på markedet. Den kan desuden medføre, at kvaliteten af de udbudte produkter bliver mere ens, fordi kvalitetskriterierne er blevet mere transparente og tilgængelige for alle. Det kan til gengæld betyde, at mere radikale innovationer ikke bliver gennemført, fordi de vil falde uden for kriterierne og/eller vil få dårlige evalueringer i tests eller mærkningsordninger. Der er også blevet fremført det argument, at en øget kvalitetstransparence på markedet besværliggør mere radikale innovationer, fordi radikalt nye produkter tit vil være behæftet med børnesygdomme, som bliver mere synlige og straffet hårdere af markedet, når der er en stor kvalitetstransparence. Information, der fremmer kvalitetstransparence, men også en forbedret klageadgang, vil derfor sørge for, at produkter, der ikke er i overensstemmelse med forbrugernes ønsker, forsvinder hurtigere fra markedet, men kan også forsinke introduktionen af nye produkter.

Effekten på producenternes innovationsproces er selvfølgelig mere udtalt i de tilfælde, hvor informationen prioriterer eller er begrænset til enkelte produktegenskaber, som har fået politisk prioritet. Det gælder fx energimærkning, som retter producenternes produktudvikling mod produkter med et lavere energiforbrug.

De ovenfor omtalte innovationseffekter af forbrugerpolitiske tiltag gælder alle tiltag, der direkte eller indirekte har til formål at øge kvalitetstransparencen for forbrugerne. Derimod er tiltag, der er rettet mod øget priskonkurrence, som udgangspunkt innovationsneutrale, medmindre de medfører en større vægt på prisen i forhold til kvaliteten. Lettere tilgængelighed af prisinformation i forhold til kvalitetsinformation kan føre til en større vægt af prisen i købsbeslutningen, selv om forbrugeren godt er klar over, at der også kan være kvalitetsforskelle mellem produkterne. Et særligt argument, der har været fremme i den forbindelse, vedrører detaillisternes konkurrence om forbrugerne ved hjælp af serviceydelser som god rådgivning og gode indkøbsforhold - det kan argumenteres, at innovationer, som vedrører den type tillægsserviceydelser, bliver forhindret, når forbrugerne opmuntres til at søge og købe varer der, hvor de er billigst. Den øgede tilgængelighed af sammenlignelig prisinformation gennem internettet, som man oplever i disse år, kan have en lignende effekt.

Man kan derfor sige, at de klassiske forbrugerpolitiske instrumenter har påvirket innovation hovedsageligt gennem to mekanismer: 
- Ved at forbedre forbrugernes muligheder for at træffe beslutninger, som så påvirker producenterne

- Ved at rette særlig fokus på politisk prioriterede produktegenskaber, som fx energiforbrug og miljøvenlighed

Der har derimod ikke været fokus på instrumenter, der medfører en analyse eller forståelse af forbrugernes behov og ønsker og deres udvikling, og heller ikke på andre mekanismer for at formidle denne type viden til producenterne end den der ligger i til- og fravalget af de produkter, der kommer på markedet. Grundidéen med forbrugerdrevet innovation er derimod, at der skal tages hensyn til eller ligefrem udgangspunkt i forbrugernes behov og ønsker før produkter kommer på markedet.

Der ligger heri en grundlæggende ændring i rammebetingelserne for innovation, som har medført et større behov for informationsstrømme mellem producenter og forbrugere, ud over dem der ligger i salgstallene for de produkter, der er kommet på markedet. Produktinnovation har igennem de seneste årtier fået betydeligt flere parametre end før. Der er større fokus på tjenesteydelser, på kombinationer af fysiske produkter og tjenesteydelser og på 'intangible' aspekter ved produktet; aspekter der kommer til udtryk mest i kommunikationen omkring produktet og mindre i produktets fysiske egenskaber. Alt det tilsammen medfører, at information om forbrugerne er en væsentlig del af produktudviklingsprocessen, før produktet lanceres på markedet - og at der derfor er behov for flere og andre kommunikationsstrømme mellem producent og forbruger.

\subsection{Muligheder for forbrugerpolitikken}

Vi har i ovenstående prøvet at argumentere for, at der er behov for politiske tiltag, der fremmer forbrugerorienteret innovation, som komplement til tiltag, der fremmer teknologiorienteret innovation. Sådanne tiltag ligger i spændingsfeltet mellem traditionel innovationspolitik og forbrugerpolitik. I det følgende kommer vi med en række forslag om disse. De er i fire kategorier: forbrugerforskning, videnstransfer i forhold til forbrugerforskning, dialogværktøjer, og tilpasning af klassiske forbrugerpolitiske værktøjer.

\subsubsection{Forbrugerforskning}

Som grundlag for forbrugerorienteret innovation er forskning om forbrugere lige så vigtigt, som teknologisk forskning er det for teknologiorienteret innovation. Relevante forskningsemner er for eksempel hvordan forbrugerbehov opstår og forandrer sig; hvordan forbrugerønsker opstår i interaktion mellem grundlæggende behov, udbuddet af produkter og andre relevante faktorer; hvordan forbrugere træffer beslutninger; hvordan købsbeslutninger indgår i forbrugernes samlede livsstil; hvilke generelle 
trends der findes, som kan påvirke mere langsigtede udviklinger i forbrugernes behovsdannelse; udvikling af nye analyseværktøjer, der kan bruges i forbrugerorienterede innovationsprojekter. Den type forskning findes til dels og er tidligere blevet kortlagt. I universitetssektoren er den spredt over en del forskellige fagdiscipliner; især marketing, psykologi og sociologi. Denne forskning finansieres af mange forskellige kilder, herunder det statslige forskningsstøttesystem. Når forbrugerorienteret innovation skal være et politisk satsningsområde under forbrugerpolitikken, er det oplagt, at den tit meget fragmenterede statslige støtte til forbrugerforskningen bliver mere systematisk orienteret mod de behov for vidensgenereringen, som netop en anvendelse af denne viden inden for innovation medfører. Udarbejdelse af et egentligt forskningsprogram for forbrugerorienteret innovation var et vigtigt første skridt. I de lande, hvor der allerede findes deciderede forbrugerforskningsinstitutter, som SIFO i Norge og Kuluttajatutkimuskeskus i Finland, vil disse kunne spille en vigtig rolle i formuleringen af et sådant forskningsprogram. Det samme gælder tilsvarende kompetencecentre i universitetssektoren, som Centrum för konsumentvetenskap ved Handelshögskolan Göteborg og MAPP Centret ved Handelshøjskolen i Århus.

\subsubsection{Videnstransfer i forhold til forbrugerforskningen}

Ligesom der som en del af den traditionelle innovationspolitik skabes mekanismer, der skal fremme udbredelsen og anvendelsen af ny teknologisk viden i praksis, bør der findes lignende tiltag, hvad angår udbredelsen og anvendelsen af viden om forbrugerforhold og om redskaber, der kan anvendes til analyse af forbrugerne - redskaber som dem, der omtales i første hoveddel af denne rapport. Det kan starte med beskedne tiltag, der skal vække interesse hos virksomhederne, give de første, grundlæggende oplysninger og hjælpe dem i gang; et eksempel på en pjece med netop dette formål gives i appendikset til denne rapport. Mere vidtgående tiltag kunne være konferencer om emnet, kurser og efteruddannelsesfor$1 ø b$.

Den infrastruktur, der findes til udbredelse af teknologisk viden, kunne udvides sådan, at den også omfatter forbrugerrelateret viden. Det gælder for eksempel de nye teknologicentre i Danmark og Innovation Norge.

Den på længere sigt måske vigtigste form for videnstransfer mellem universitetsforskningen og praksis er også her de videregående uddannelser. Som tidligere nævnt indgår forskningsbaseret viden om forbrugerforhold i dag hovedsageligt i marketing-specialiseringerne inden for de erhvervsøkonomiske uddannelser, og også der er det meget forskelligt, hvor meget vægt det får. Der findes også spæde forsøg på at integrere denne type viden $\mathrm{i}$ ingeniøruddannelserne. Her kunne der gøres meget mere, gerne i samarbejde mellem universiteterne, industrien og de politiske instanser, der har interesse i forbrugerorienteret innovation. Dette er i tråd 
med de forslag, der er kommet fra Danmarks Erhvervsråd vedr. brugerdrevet innovation.

\subsubsection{Dialogverktøjer}

De ovenfor omtalte tiltag til fremme af videnstransfer skaber dialog mellem producenter af forskningsbaseret viden om forbrugerforhold og mulige aftagere af denne viden. Desuden kan der være instrumenter, der fremmer udveksling af erfaring med forbrugerorienteret innovation mellem virksomheder, og der kan være instrumenter, der skaber nye former for informationsflow mellem forbrugere og virksomheder. Det første kan være ERFA grupper og meeting places, hvor det politiske tiltag er begrænset til at tage initiativet og sørge for den nødvendige infrastruktur. De tiltag, der involverer deltagelse fra selve forbrugerne, skal derimod være en del mere innovative. Her kunne der fx være tale om foresightstudier, hvor forbrugerne involveres i strukturerede processer, hvor der skal udvikles branchespecifikke fremtidsscenarier. Der kunne også være tale om konsensus-møder, hvor forbrugere og producenter bliver enige om, hvor centrale udfordringer inden for en given branche ligger.

Et vanskeligt spørgsmål med denne type tiltag er, hvilke forbrugere der bør indgå. Skal det være et repræsentativt udsnit, skal det være forbrugere, der er på forkant med udviklingen, dvs. lead users, eller skal det være forbrugerrepræsentanter, som forbrugerorganisationerne stiller med? Det sidste sker jo allerede i nogen omfang, men det er tit lidt uklart, om repræsentanterne fra forbrugerorganisationerne optræder som eksperter eller som egentlige repræsentanter for en større gruppe forbrugere, og hvis det sidste er tilfældet, hvilken gruppe drejer det sig så om? I hvert fald er det værd at tænke over, om andre fora med ikke-professionelle forbrugerrepræsentanter kunne være nyttige, fx oprettelsen af et egentligt repræsentativt forbrugerpanel, som kan bruges til at undersøge trends i forbrugsmønstre, trends i livsstile og forbrugerværdier samt forandringer i de faktorer, der medfører, at forbrugere ser en værdi i nye produkter. Det kunne også være et lead user panel med forbrugere, der efter fastlagte kriterier vurderes som værende på forkant med udvalgte trends.

Nogle af de her omtalte forslag kunne gennemføres gennem en udvidelse af de mere klassiske forbrugerpolitiske instrumenter, jvf. forslagene i næste afsnit.

\subsubsection{Tilpasning af klassiske forbrugerpolitiske varktøjer}

Et klassisk forbrugerpolitisk instrument $\mathrm{i}$ de nordiske lande er at give forbrugerne en let klageadgang, enten ved at oprette uafhængige nævn eller ved at skabe centrale klageinstanser hos forbrugermyndighederne. Disse nævn og myndigheder kommer derfor i besiddelse af omfattende viden om problemer, som forbrugerne opfatter i forbindelse med produkter og serviceydelser, og som kunne være en vigtig informationskilde til forbrugerorienterede produktforbedringer hos producenterne. De institu- 
tioner, der står for klagebehandlingen, kunne foretage en bearbejdning af klagerne og stille den aggregerede viden til rådighed for producenterne. Forslaget er specielt oplagt i lyset af den diskussion der har været om complaint management som vigtig informationskilde for virksomhederne, og i lyset af forsøgene på at oprette lignende funktioner virksomhedsinternt $\mathrm{i}$ form af consumer affairs departments. Et lignende forslag er blevet fremlagt $i$ en rapport med anbefalinger om tiltag til fremme af brugerdrevet innovation $\mathrm{i}$ den danske Forbrugerstyrelse (Competence House, 2005).

Et andet klassisk forbrugerpolitisk instrument er at gennemføre produkttests. Disse går traditionelt ud på, at man måler udvalgte produkters objektive kvalitet på en række dimensioner. Resultaterne er, som omtalt ovenfor, mest beregnet til at forbedre forbrugernes beslutningsgrundlag, men påvirker indirekte også produktinnovation mod en forbedring af kvaliteten i retning af de dimensioner, der bliver målt i testen. Man kunne erstatte eller supplere den objektive kvalitetsvurdering med en undersøgelse af forbrugernes subjektive kvalitetsopfattelse, for eksempel ved at gennemføre en række workshops hvor forbrugerne skal afprøve produkterne under forskellige betingelser, eller ved at observere forbrugernes brug af produkterne i deres ejet hjem. Ligesom ingeniører almindeligvis har ansvaret for måling af den objektive kvalitet, så bør specialister med kompetence i analyse af forbrugerbehov og -ønsker få ansvar for at analysere de data, der kommer ud af denne form for workshops eller in-home tests. Resultaterne skal så bearbejdes i en sådan form, at de kan kanaliseres videre til alle aktører, der er interesseret $\mathrm{i}$ inspiration til forbrugerorienteret innovation. 



\section{Konklusion}

Denne rapport handler om muligheder for mere forbrugerdrevet innovation. Vi har defineret begrebet som en proces mod udviklingen af et nyt produkt eller en ny serviceydelse, hvor en analyse og forståelse af forbrugernes behov og præferencedannelse spiller en afgørende rolle. Vi har skitseret en teoretisk ramme, der giver retningslinier for, hvilken type oplysninger der er vigtige for at kunne gennemføre forbrugerdrevet innovation. Vi har så gennemgået en lang række værktøjer, der kan hjælpe virksomheder med at være mere forbrugerdrevne i deres innovationsproces - nogle velkendte og nogle af nyere dato. En række cases har illustreret anvendelsen af nogle af disse værktøjer.

Vi har så sat fokus på de politiske rammebetingelser, der kan fremme forbrugerdrevet innovation. Der er her tale om et grænseområde mellem innovationspolitik og forbrugerpolitik: innovationspolitik traditionelt har det formål at fremme innovation, mens forbrugerpolitik har traditionelt det formål at fremme forbrugernes vilkår. Her mødes begge formål: det handler om at fremme forbrugernes vilkår gennem innovation. Der er derfor lagt op til et samarbejde mellem disse to traditionelle politikområder, som hver især kan bidrage med deres særkompetencer. Vi har argumenteret for, at de klassiske argumenter for overhovedet at have innovationsfremmende tiltag gælder i lige så høj grad for forbrugerdrevet som for teknologidrevet innovation. Vi har desuden argumenteret for, at en udvidelse af nogle klassiske forbrugerpolitiske instrumenter kunne yde et vigtigt bidrag til fremme af forbrugerdrevet innovation.

Forbrugerdrevet innovation som politikemne er forholdsvist nyt, men må forventes at få stigende betydning. Der er en bred erkendelse af, at konkurrenceevnen i stigende grad skal hvile på både god kundeforståelse og fremadrettet teknologi, og at særlige gode evner i forhold til det ene ikke kan kompensere for mangler ved det andet. Der er også en bred erkendelse af, at ny teknologi skal være til gavn for forbrugerne, og at en god forståelse af forbrugerholdninger og -præferencer er en forudsætning for udnyttelse af ny teknologi. 



\section{Sammenfatning: Innovation og forbrugerkvalitet}

Innovation knyttes ofte til teknologisk forskning og udvikling. Men innovation handler også om at opspore uopfyldte behov blandt forbrugerne og udvikle produkter og serviceydelser, som matcher disse behov. Rapporten fokuserer på forbrugerinvolvering og brugerdreven innovation, som er 'en proces mod udviklingen af et nyt produkt eller en ny serviceydelse, hvor en analyse og forståelse af brugernes behov og præferencedannelse spiller en afgørende rolle.'

Det undersøges:

- Hvordan koblingen mellem forbrugernes behov og producenternes innovationsprocessor forbedres.

- Hvordan forbrugerpolitikken kan bidrage til bedre forbrugerorienteret innovation i virksomhederne.

Det er dog ikke let at være innovativ eller udføre brugerdreven innovation. Det viser sig ved, at de fleste nye produkter ikke bliver en succes. Hermed har producenterne spildt ressourcer, og forbrugerne får ikke de produkter, de kunne ønske sig. Det er derfor oplagt at undersøge, hvorledes forbrugerne mere aktivt kan involveres i innovationsprocessen. Hvordan kan kommunikationen mellem forbrugere og virksomheder forbedres, så nye produkter målrettes til forbrugernes behov før de kommer på markedet?

I en tidligere rapport (Forbrugerkvalitet, TemaNord 2004:566) blev der sat fokus på virksomhedernes rolle i forbrugerpolitikken. Det skete ved at kortlægge og vurdere initiativer, som virksomheder og brancher har igangsat for at fremme forbrugerkvaliteten i form af god service og positive kundeforhold. Rapporten identificerede tre områder (complaint management systems, skræddersyet forbrugerinformation og nye former for forbrugerinvolvering), som værende særlig interessante for fremme af god forbrugerkvalitet og positive forbrugerforhold.

Denne rapport gennemgår en række værktøjer, som virksomhederne kan benytte i forbindelse med indsamling af viden om forbrugernes præferencer. Dernæst følger syv virksomhedscases med eksempler på brug af redskaberne $\mathrm{i}$ innovationssammenhæng. 
Casene omhandler:

- Amager Strandpark: En tidlig anvendelse af fokusgrupper til brug for indsamling af oplysninger om brugernes ønsker til stranden.

- Nutana: Vha. laddering-interviews undersøges forbrugernes vurderinger af mulige nye produkter. Hvilke egenskaber vurderer forbrugerne vigtige? Og hvorfor netop disse?

- 3M: En målsætning om, at 30 pct. af omsætningen hvert år skal komme fra produkter, som er mindre end fem år gamle, søges opfyldt ved brug af lead users.

- Marriott: Gennem conjoint analyse belyses produktegenskabers relative betydning for kundernes tilfredshed med den samlede ydelse.

- Post Danmark: Kundetilfredshedsanalyse bruges til at identificere virksomhedens udfordringer.

- Dean Foods: Etableringen af en consumer affairs afdeling, der tager sig af, indsamler og systematiserer kundehenvendelser.

På baggrund af en række ekspertinterviews i de nordiske lande er det undersøgt, hvorvidt traditionelle innovationspolitiske instrumenter, det være sig finansiering af offentlig forskning mm., er lige så relevante for forbrugerorienteret som for teknologidrevet innovation. Hovedkonklusionen er, at behovet for tiltag til fremme af vidensdeling om forbrugerforhold, er mindst lige så stor som behovet for tiltag, der kan fremme vidensdeling omkring teknologirelaterede forhold.

Sidste del af rapporten indeholder en pjece om forbrugerdrevet innovation rettet mod virksomheder. Der er tale om en art værktøjskasse, som er tænkt som en vidensdeling til og indgangshjælp for virksomheder, der står foran at involvere forbrugerne i deres innovations- og udviklingsbestræbelser. Fokus er på at identificere muligheder for nye produkter eller produktforbedringer gennem øget forbrugerforståelse og -involvering. Guiden illustrerer, at der er mange forskellige måder og muligheder for at involvere forbrugerne, samt at det er vigtigt på forhånd at gøre sig ambitionsniveauet klart.

Et eksempel fra Dean Foods viser, at en begrænset innovation som tilføjelse af et 'twist off' på emballagen kan reducere antallet af forbrugerklager med 78 pct. Det illustrerer, at forbrugernes vilkår kan fremmes gennem innovation, samt at innovationen kan gøres mere effektiv gennem involvering af forbrugerne. Forhåbentlig vil sammenhængen mellem innovations- $\mathrm{g}$ forbrugerpolitik blive mere eksplicit $\mathrm{i}$ tiden fremover. 


\section{Summary: Innovation Processes and Consumer Quality}

Innovation is often considered part and parcel of technological research and development. Yet innovation is also related to the discovery of unfulfilled needs - and how to come up with products and services to meet these needs. This report focuses on direct consumer input and user driven innovation which is defined as "a process towards developing new product or service concepts in which the ability to understand and address consumer needs and preference formation on the basis of analysis is crucial".

This report discusses:

- How the interaction between consumer needs on the one hand and producer innovation processes on the other can be improved

- How consumer policies may contribute to more efficient consumeroriented innovation in business and trade

It is not easy to be innovative or pursue user driven innovation. This is evident from the fact that most new product concepts flop. Short of having developed the desired product for the market and the consumers, the trader has also wasted valuable resources. Therefore it seems highly pertinent to examine how direct consumer input could play a part in the innovation process. How do we best facilitate user/producer communication to ensure that new product concepts are tailored to suit specific needs before they are launched?

A previously released report (Consumer Quality, Tema Nord 2004:566) focused on the influence exerted on consumer policies by business and trade. By mapping out and assessing initiatives launched to enhance consumer quality as regards good service and positive customer relations, the report identified three areas - complaint management systems, targeted consumer information and new types of consumer input as being of paramount interest in relation to further development of consumer quality and positive conditions for consumers.

This report goes through a number of tools available to business and trade in connection with the collection of information about consumer preferences. This is followed by seven business case studies which look into how the enterprises have used these tools for innovation purposes. 
These cases focus on:

- Amager Beach - Focus groups were involved early on in the process in order to collect information about user preferences for the beach.

- Nutana - laddering interviews are conducted to map out how new product concepts are received by the consumers. Which properties are deemed important - and why?

- $3 \mathrm{M}$ - The goal that 30 per cent of the annual turnover should come from product concepts not going further back than five years was sought achieved by means of using lead users.

- Mariott - Conjoint analysis techniques are applied when investigating the relative importance of product properties in connection to customer satisfaction with the overall performance.

- Post Danmark - customer satisfaction surveys are conducted to pin down and identify the challenges faced by the postal service itself.

- Dean Foods - a consumer affairs department has been introduced to handle, collect and systematise customer enquiries.

On the basis of a number of expert interviews in the Nordic countries it was examined whether conventional ways of thinking about innovation and how to kick-start the processes behind, e.g. by funding public research etc. had the same bearing on consumer-oriented innovation as it is known to have on technology-driven innovation. The need to spur information exchange initiatives regarding the market conditions consumers are facing turned out to be at least as important as the need for initiatives that lead to more exchange of information in relation to technological conditions.

The last part of the report contains a leaflet about demand-driven innovation targeted to business and trade. A kind of guide to information exchange, the leaflet is meant as a start kit for businesses which wish to employ consumer inputs for innovation or development purposes. The leaflet focuses on how to identify and discover new product concepts or improvements through a better understanding of consumer demand and involvement. The leaflet also explicates that, while the possibilities and ways in which consumers can be involved in innovation processes are numerous, it remains important to have decided on one's level of ambition beforehand.

An example from Dean Foods shows how even a rather small innovation initiative such as adding a "twist off" to the packaging reduced the number of consumer complaints by 78 per cent. It drives home the point that consumer welfare can be improved by means of innovation processes. These processes may then also become more efficient and profitable through consumer input. Hopefully the interconnection between innovation and consumer policies will become all the more evident in the near future. 


\section{Yhteenveto: Innovaatioprosessit ja kuluttajalaatu}

Innovaation katsotaan usein olevan olennainen osa teknologista tutkimusta ja kehitystä. Innovaatio liittyy kuitenkin myös tyydyttämättömien tarpeiden havaitsemiseen - ja siihen miten näiden tarpeiden tyydyttämiseksi voidaan tarjota tuotteita ja palveluja. Tämä raportti keskittyy suoraan kuluttajapanokseen ja käyttäjälähtöiseen innovaatioon, joka määritellään "uusien tuote- tai palvelukonseptien kehittämisprosessiksi, jossa analyysiin perustuva kuluttajan tarpeiden ja toiveiden muodostuksen ymmärtäminen ja niihin vastaaminen on olennaisen tärkeää".

Tässä raportissa pohditaan:

- Miten kuluttajatarpeiden ja tuottajan innovaatioprosessien välistä vuorovaikutusta voidaan parantaa

- Miten kuluttajapolitiikka voi vaikuttaa tehokkaampien kuluttajalähtöisten innovaatioiden syntymiseen elinkeinoelämässä

Innovatiivisuus ja kuluttajalähtöisten innovaatioiden kehittäminen ei ole helppoa. Tämä näkyy siinä, että useimmat uudet tuotekonseptit epäonnistuvat. Paitsi että halutun tuotteen kehittäminen markkinoille ja kuluttajille on epäonnistunut, yritys on myös kuluttanut arvokkaita resursseja. Tämän vuoksi on paikallaan tutkia, millä tavoin suora kuluttajapanostus voisi toimia osana innovaatioprosessia. Miten voimme parhaiten helpottaa käyttäjän ja tuottajan välistä yhteydenpitoa varmistaaksemme, että uudet tuotekonseptit on räätälöity sopimaan yhteen tiettyjen tarpeiden kanssa ennen kuin ne tuodaan markkinoille?

Aiemmin julkistettu raportti (Consumer Quality, Tema Nord 2004:566) keskittyi selvittämään elinkeinoelämän vaikutusta kuluttajapolitiikkaan. Kartoittamalla ja arvioimalla aloitteita, jotka on käynnistetty kuluttajalaadun parantamiseksi hyvän palvelun ja positiivisten asiakassuhteiden osalta, raportti löysi kolme aluetta - valitusten hallintajärjestelmät, suunnatun kuluttajainformaation ja uudentyyppiset kuluttajapanokset - jotka ovat erittäin kiinnostavia kuluttajalaadun ja myönteisten kuluttajaolosuhteiden edelleenkehittämisen kannalta.

Tämä raportti käy läpi elinkeinoelämän käytettävissä olevia työkaluja, jotka soveltuvat kuluttajamieltymyksiä koskevan tiedon keruuseen. Tämän jälkeen esitellään seitsemän tapaustutkimusta yrityksistä, jotka ovat käyttäneet näitä välineitä innovaatiotarkoituksiin. 
Nämä ovat:

- Amagerin ranta - Tutkimusryhmät tulivat mukaan prosessiin varhaisessa vaiheessa keräämään tietoa käyttäjien rantaa koskevista mieltymyksistä

- Nutana - portaittaisten haastattelujen avulla kartoitetaan, miten kuluttajat vastaanottavat uudet tuotekonseptit. Mitä ominaisuuksia pidetään tärkeinä - ja miksi?

- $3 \mathrm{M}$ - Yrityksen tavoitteena oli, että 30 prosenttia vuotuisesta liikevaihdosta tulisi viittä vuotta tuoreemmista tuotekonsepteista. Tähän tavoitteeseen yritettiin päästä johtavien käyttäjien avulla.

- Mariott - Yhdistettyjä analyysitekniikoita käytetään tutkittaessa tuotteen ominaisuuksien merkitystä sille, miten tyytyväisiä kuluttajat olivat tuotteen kokonaissuorituskykyyn.

- Post Danmark - asiakastyytyväisyyskyselyjä tehdään postipalvelun ongelmakohtien selvittämiseksi.

- Dean Foods - yritykseen on perustettu kuluttaja-asiain osasto, jonka tehtävänä on käsitellä, kerätä ja systematisoida asiakkaiden tiedusteluja.

Lukuisten Pohjoismaissa suoritettujen asiantuntijahaastattelujen perusteella tutkittiin, oliko perinteisillä tavoilla ajatella innovaatiota ja antaa potkua jälkeen jääneille prosesseille - esimerkiksi rahoittamalla tutkimustoimintaa julkisin varoin - sama vaikutus kuluttajalähtöiseen innovaatioon kuin sillä tiedetään olevan teknologiavetoiseen innovaatioon. Tarve edistää aloitteita, jotka koskevat tiedonvaihtoa niistä markkinaolosuhteista, joissa kuluttajat elävät, osoittautui ainakin yhtä tärkeäksi kuin tarve edistää aloitteita, jotka johtavat teknologisia olosuhteita koskevan tiedonvaihdon lisääntymiseen.

Raportin viimeinen osa sisältää elinkeinoelämälle suunnatun esitteen kysyntävetoisesta innovaatiosta. Esite on eräänlainen tiedonvälityksen opas, ja se on tarkoitettu aloituspaketiksi yrityksille, jotka haluavat hyödyntää kuluttajien panosta innovaatio- tai kehitystyössä. Esite keskittyy uusien tuotekonseptien tai parannusten tunnistamiseen ja löytämiseen kulutuskysynnän ja kuluttajien paremman ymmärtämisen kautta. Esitteessä painotetaan myös, että vaikka kuluttajat voivat olla mukana innovaatioprosesseissa monella eri tavalla, tavoitetasosta on hyvä päättää etukäteen.

Dean Foodsilta peräisin oleva esimerkki osoittaa, miten melko pienikin innovaatioaloite, kuten twist-off-kannen lisääminen pakkaukseen, vähensi kuluttajavalituksia 78 prosenttia. Tämä on konkreettinen osoitus siitä, että kuluttajien hyvinvointia voidaan parantaa innovaatioprosessien avulla. Nämä prosessit saattavat tällöin myös kuluttajien panoksen avulla muuttua tehokkaammiksi ja tuottavimmiksi. Olisi toivottavaa, että innovaation ja kuluttajapolitiikan välinen yhteys kävisi lähitulevaisuudessa entistä selvemmäksi. 


\section{Referencer}

Akao, Y. (1990). Quality function deployment integrating customer requirements into product design. Cambridge, MA: Productivity Press.

Bech-Larsen, T., \& Nielsen, N. A. (1999). A comparison of five elicitation techniques for elicitation of attributes of low involvement products. Journal of Economic Psychology, 20, 315-341.

Beyer, H., \& Holtzblatt, K. (1998). Contextual design: Defining customer-centered systems. San Francisco, CA: Kaufman.

Biemans, W. G. (1991). User and thirdparty involvement in developing medical equipment innovations. Technovation, 11(3), 163-182.

Calder, B. J. (1977). Focus groups and the nature of qualitative marketing research. Journal of Marketing Research, 14, 353-364.

Carroll, J. D., \& Green, P. E. (1995). Psychometric methods in marketing research: Part i, conjoint analysis. Journal of Marketing Research, 32, 385-391.

Carroll, J. D., \& Green, P. E. (1997). Psychometric methods in marketing research: Part II, multidimensional scaling. Journal of Marketing Research, 34, 193-204.

Christensen, G. L., \& Olsen, J. C. (2002). Mapping consumers' mental models with zmet. Psychology \& Marketing, 19, 477-502.

Comptencehouse (2005). Brugerdreven innovation - Forslag til Forbrugerstyrelsens arbejde med brugerdreven innovation. København: Competencehouse.

Cooper, R. G. (1984). New product strategies: What distinguishes the top performers? Journal of Product Innovation Management, 1, 151-164.

Coulter, R. A., Zaltman, G., \& Coulter, K. S. (2001). Interpreting consumer perceptions of advertising: An application of the Zaltman Metaphor Elicitation Technique. Journal of Advertising, 30(4).
Crawford, C. M. (1997). New products management (5th ed.). Chicago, IL: Irwin.

Danmarks Erhvervsråd (2005). Danmarks Erhvervsråds handlingsplan for brugerdreven innovation. København: Danmarks Erhvervsråd.

Darby, M. R., \& Karni, E. (1973). Free competition and the optimal amount of fraud. Journal of Law and Economics, 16, 67-88.

Day, R. G. (1993). Quality function deployment: Linking a company with its customers. Milwaukee, WI: ASQC Quality Press.

Epting, F. R., Suchman, D. I., \& Nickeson, C. J. (1971). An evaluation of elicitation procedures for personal constructs. British Journal of Psychology, 62, 513-517.

Fahey, L., \& Randall, R. M. (Eds.). (1998). Learning from the future. New York: Wiley.

Fornell, C. (1978). Corporate consumer affairs departments - a communications perspective. Journal of Consumer Policy, 2, 289-302.

Fornell, C. (1992). A national customer satisfaction barometer: The Swedish experience. Journal of Marketing, 56, 6-21.

Fornell, C., \& Wernerfelt, B. (1988). A model for customer complaint management. Marketing Science, 7, 287298.

Fornell, C., Johnson, M. D., Anderson, E. W., Cha, J., \& Bryant, B. E. (1996). The American Customer Satisfaction Index: Nature, purpose, and findings. Journal of Marketing, 60(4), 7-18.

Franke, N., \& Shah, S. (2003). How communities support innovative activities: An exploration of assistance and sharing among end users. Research Policy, 32, 157-178.

Fuller, G. W. (1994). New food product development, from concept to marketplace. Boca Raton: CRC Press. Gassmann, O., \& Wecht, C. H. (2005). Early customer integration into the 
innovation process. Paper presented at the 12th International Product Development Conference, Copenhagen.

Godet, M., \& Roubelat, F. (1996). Creating the future: The use and misuse of scenarios. Long Range Planning, 29, 164-171.

Goldenberg, J., \& Mazursky, D. (2002). Creativity in product innovation. Cambridge: Cambridge University Press.

Green, P. E., \& Rao, V. R. (1972). Applied multidimensional scaling: A comparison of approaches and algorithms. New York: Holt, Rinehart and Winston.

Green, P. E., Krieger, A. M., \& Wind, Y. (2001). Thirty years of conjoint analysis: Reflections and prospects. Interfaces, 31(3), 56-73.

Griffin, A., \& Hauser, J. R. (1993). The voice of the customer. Marketing Science, 12, 1-27.

Grunert, K. G. (1990). Kognitive Strukturen in der Konsumforschung Entwicklung und Erprobung eines Verfahrens zur offenen Erhebung assoziativer Netzwerke. Heidelberg: Physica.

Grunert, K. G. (2005a). Consumer behaviour with regard to food innovations: Quality perception and decision-making. In W. M. F. Jongen \& M. T. G. Meulenberg (Eds.), Innovation in agri-food systems (1st ed., pp. 57-85). Wageningen: Wageningen Academic Publishers.

Grunert, K. G. (2005b). Food quality and safety: Consumer perception and demand. European Review of Agricultural Economics, 32, 369-391.

Grunert, K. G., \& Grunert, S. C. (1995). Measuring subjective meaning structures by the laddering method: Theoretical considerations and methodological problems. International Journal of Research in Marketing, 12, 209-225.

Gutman, J. (1982). A means-end chain model based on consumer categorization processes. Journal of Marketing, 46(2), 60-72.

Hansen, U., Jeschke, K., \& Schöber, P. (1995). Beschwerdemanagement - die Karriere einer kundenorientierten Unternehmensstrategie im Konsumgütersektor. Marketing. ZFP, 17(2), 7788.
Hart, S. (Ed.). (1996). New product development: A reader. London: The Dryden Press.

Heijden, K. v. d. (1996). Scenarios: The art of strategic conversation. Chichester: Wiley.

Henard, D. H., \& Szymanski, D. M. (2001). Why some new products are more successful than others. Journal of Marketing Research, 38, 362-375.

Henderson, C. (2000). Finding, examining lead users push $3 \mathrm{~m}$ to leading edge of innovation, The CEO Refresher. http://www.refresher.com/!leadusers

Herstatt, C., \& von Hippel, E. (1992). From experience: Developing new product concepts via the lead user method: A case study in a "low-tech" field. Journal of Product Innovation Management, 9, 213-221.

Holt, K., Geschka, H., \& Peterlongo, G. Need assessment - a key to useroriented product innovation. Chichester: Wiley.

Jaumotte, F. \& Pain, N. (2005). An overview of public policies to support innovation. Paris: OECD.

Juhl, H. J., Kristensen, K., \& Østergaard, P. (2002). Customer satisfaction in European food retailing. Journal of Retailing and Consumer Services, 9, 327-334.

Kaul, A., \& Rao, V. (1995). Research for product positioning and design decisions: An integrative review. International Journal of Research in Marketing, 12, 293-320.

Kelly, G. A. (1955). The psychology of personal construct. New York, NY: Norton.

Ketola, P., \& Ahonen, M. (2005). Learning and innovating between users and developers within new technology development. Paper presented at the 12th International Product Development Conference, Copenhagen.

Kristensen, K., Martensen, A., \& Grønholdt, L. (2000). Measuring customer satisfaction: A kye dimension of business performance. International Journal of Business Performance Management, 2, 157-170.

Leonard, D., \& Rayport, J. F. (2000). Spark innovation through empathic design. Harvard Business Review, 48(6), 102-113. 
Leonard-Barton, D. (1995). Wellsprings of knowledge. Boston, MA: Harvard Business School.

Lilien, G. L., \& Rangaswamy, A. (1998). Marketing engineering: Computer-assisted marketing analysis and planning. Reading, MA: AddisonWesley.

Lilien, G. L., Morrison, P. D., Searls, K., Sonnack, M., \& von Hippel, E. (2002). Performance assessment of the lead user idea-generation process for new product development. Management Science, 48, 1042-1059.

Lüthje, C. (2003). Characteristics of innovating users in a consumer goods field: An empirical study of sportrelated product consumers. Technovation, 24, 683-695.

Mangold, W. (1960). Gegenstand und Methode des Gruppendiskussionsverfahrens. Frankfurt: Europäische Verlagsanstalt.

Martensen, A. (1993). A model for marketing planning for new products. Marketing and Research Today, 247267.

Mayhew, D. J. (1999). The usability engineering lifecycle. San Francisco, CA: Kaufman.

McQuarrie, E. F., \& McIntyre, S. H. (1986). Focus groups and the development of new products by technologically driven companies: Some guidelines. Journal of Product Innovation Management, 1, 40-47.

Moore, W. L., Louviere, J. J., \& Verma, R. (1999). Using conjoint analysis to help design product platforms. Journal of Product Innovation Management, 16, 27-39.

Nelson, P. (1970). Information and consumer behavior. Journal of Political Economy, 7, 311-329.

Nielsen, N. A., Sørensen, E., \& Grunert, K. G. (1997). Consumer motives for buying fresh or frozen plaice: A means end chain approach. In J. B. Luten, T. Børresen \& J. Oehlenschläger (Eds.), Seafood from producer to consumer: Integrated approach to quality (pp. 31-43). Amsterdam: Elsevier.

Nijssen, E. J., \& Lieshout, K. F. M. (1995). Awareness, use and effectiveness of models and methods for new product development. European Journal of Marketing, 29(10), 27-44.
Nyholm, J. \& Langkilde, L. (2003). Et benchmark studie af innovation og innovationspolitik - hvad kan Danmark lære? København: FORA.

Oliver, R. L. (1997). Satisfaction: A behavioral perspective on the consumer. Boston, MA: Irwin/McGrawHill.

Olson, J. C., \& Jacoby, J. (1972). Cue utilization in the quality perception process. In Third annual conference of the association for consumer research (pp. 167-179). Chicago.

Ozer, M. (1999). A survey of new product evaluation models. Journal of Product Innovation Management, 16, 77-94.

Poh, K. L., Ang, B. W., \& Bai, F. (2001). A comparative analysis of r\&d project evaluation methods. R \& D Management, 31, 63-75.

Raffee, H., \& Silberer, G. (1984). Warentest und Unternehmen - Nutzung, Wirkungen und Beurteilung des vergleichenden Warentests in Industrie und Handel. Frankfurt: Campus.

Reynolds, T. J., \& Gutman, J. (1988). Laddering theory, methods, analysis, and interpretation. Journal of Advertising Research, 18(1), 11-31.

Rochford, L. (1991). Generating and screening new product ideas. Industrial Marketing Management, 20, 287296.

Rokeach, M. (1973). The nature of human values. New York, NY: Free Press.

Rosted, J. (2005). Brugerdreven innovation - resultater og anbefalinger. København: FORA.

Sampson, P. (1972). Using the repertory grid test. Journal of Marketing Research, 9, 78-81.

Schwartz, P. (1991). The art of the long view: Currency Doubleday.

Schwartz, S. H., \& Bilsky, W. (1987). Toward a universal psychological structure of human values. Journal of Personality and Social Psychology, 53, 550-562.

Søndergaard, H. A. (2003). Markedsorienteret produktudvikling med en means-end chain tilgang. Ph.d.afhandling, Handelshøjskolen i Århus.

Souder, W. E. (1989). Managing new product innovations. Lexington, MA: Lexington Books. 
Steenkamp, J.-B. E. M. (1990). Conceptual model of the quality perception process. Journal of Business Research, 21, 309-333.

Stephens, N., \& Gwinner, K. P. (1998). Why don't some people complain? A cognitive-emotive process model of consumer complaint behaviour. Journal of the Academy of Marketing Science, 26, 172-189.

Thomson, D. M. H., \& McEwan, J. A. (1988). An application of the repertory grid method to investigate consumer perceptions of foods. Appetite, 10, 181-193.

Tidd, J., \& Bodley, K. (2002). The influence of project novelty on the new product development process. R\&D Management, 32, 127-138.

Urban, G. L., \& Hauser, J. R. (1993). Design and marketing of new products (2nd ed.). Englewood Cliffs, NJ: Prentice-Hall.

Urban, G. L., \& von Hippel, E. (1988). Lead user analyses for the development of new industrial products. Management Science, 34, 569-582.

van Kleef, E., van Trijpa, H. C. M., \& Luningb, P. (2005). Consumer research in the early stages of new product development: A critical review of methods and techniques. Food Quality \& Preference, 16, 181201.

von Hippel, E. (1978). Successful industrial products from customer ideas. Journal of Marketing, 42(1), 39-49.

von Hippel, E. (1986). Lead users: A source of novel product concepts. Management Science, 32(7), 791-805. von Hippel, E. (1988). The sources of innovation. Oxford: Oxford University Press.

von Hippel, E., \& Sonnack, M. (1999). Breakthroughs to order at 3M. MITSSM Working Paper. Cambridge, MA: MIT.

Wind, J., Green, P. E., Shifflet, D., \& Scarbrough, M. (1989). Courtyard by marriott: Designing a hotel facility with consumer-based marketing models. Interfaces, 19(1), 25-47.

Wright, G., \& Ayton, P. (Eds.). (1987). Judgmental forecasting: John Wiley \& Sons Ltd.

Zaltman, G. (1997). Rethinking market research: Putting people back in. Journal of Marketing Research, 34, 424-437.

Zaltman, G., \& Higie, R. A. (1993). Seeing the voice of the customer: The zaltman metaphor elicitation technique (Working paper No. 93-114). Cambridge, MA: Marketing Science Institute.

Zeithaml, V. A. (1998). Consumer perceptions of price, quality, and value: A means-end model and synthesis of evidence. Journal of Marketing, 52(3), 2-22 


\section{Appendiks A: Liste over interviews}

Interview med Bent Sunde, afdelingsdirektør i sektion for innovationspolitik, Nærings- og Handelsdepardementet, Oslo - Onsdag d. 19.10.05 kl. 12.00

Interview med Eivind Stø, forskningschef i Statens Institutt for Forbruksforskning (SIFO), Oslo - Onsdag d. 19.10.05 kl. 14.00

Interview med Hans Müller Pedersen, vicedirektør i Ministeriet for Videnskab, Teknologi og Udvikling (VTU), København - Mandag d. 05.12.05 k1. 12.30

Interview med Henrik Nepper-Christensen, departementschef i Ministeriet for Familie- og Forbrugeranliggender, København - Mandag d. 05.12.05 kl. 14.00

Interview med Petteri Repo Research Manager ved National Consumer Research Centre, Helsinki - Fredag d. 16.09.05 kl. 10.00

Interview med Tero Kuitunen, Senior Advisor ved The Technology Department in the Ministry of Trade and Industry, Helsinki - Fredag d. 16.09 .05 kl. 14.00

Interview med Tove Frederiksen, projektleder i Amager Strandpark, København - Onsdag d. $16.11 .05 \mathrm{kl} .13 .00$

Interview med Peter Hatlö, analysechef i Post Danmark, København Torsdag d. $26.01 .06 \mathrm{kl} .10 .00$ 



\section{Appendiks B: Interviewguides}

Nedenstående interviewguides er versionen, der blev brugt i Norge; interviewguides i Danmark og Finland var let tilpassede versioner.

\section{Interview guide consumer policy}

1. What are generally the aims of Norwegian consumer policy, and what are its main instruments (e.g., consumer protection, information, advice)?

2. To which extent aims Norwegian consumer policy at improving the supply of goods and services?

a) In terms of the quality of goods and services?

b) In terms of the price of goods and services?

c) In terms of aligning the supply of goods and services with the wishes of consumers?

3. Measures to improve the supply of goods and services to consumers can be aimed at producers/sellers, at consumers, or at intermediaries, for example those providing information.

a) Which measures are aimed at producers?

b) Which measures are aimed at consumers - for example making it easier for them to voice complaints are otherwise be heard?

c) Which measures are aimed at third parties?

4. In many Western countries, innovation is regarded as desirable from a societal point of view. How is innovation viewed from the consumer policy perspective?

a) Is innovation in the private sector viewed as beneficial for the consumer? Which types of innovation are viewed as beneficial, which not?

b) Much innovation is technology-driven. Do you regard technologically-driven innovation as beneficial to the consumer? What determines whether it is beneficial or not?

c) Other types of innovation result from that companies, for example based on market research, believe they have found a niche in the market which is not yet taken by others. Do you regard this type of innovation as beneficial to the consumer? What determines whether it is beneficial or not?

d) Are there types of innovation which you, from the perspective of benefits for consumers, would regard as desirable, but which are not occurring? 
5. Can you briefly describe Norwegian government policy with regard to innovation?

6. Do you think this policy is beneficial to the consumer?

7. How would you describe innovation that is in the consumer interest?

a) Is this type of innovation occurring in Norway?

b) What may be barriers against more innovation that is in the consumer interest?

c) What facilitates innovation that is in the consumer interest?

8. In your opinion, is innovation a topic for consumer policy? If yes, how should consumer policy deal with it?

a) In terms of affecting companies?

b) In terms of helping consumers?

c) In terms of addressing the interface between consumers and companies?

d) In terms of other actors like research institutions? 


\section{Interview guide innovation policy}

9. What are generally the aims of Norwegian innovation policy, and what are its main instruments (e.g., research, technology transfer, public-private cooperations) ?

10. To which extent aims Norwegian innovation policy at

a) Improving the competitiveness of Norwegian industry?

b) Improving the welfare of Norwegian citizens?

11. Measures to encourage innovation can be aimed at research institutions, at industry, and at intermediaries, for example those providing technology transfer.

a) Which measures are aimed at research institutions?

b) Which measures are aimed at industry?

c) Which measures are aimed at third parties?

12. How is innovation viewed in society?

a) As beneficial for the Norwegian economy?

b) As beneficial to the individual citizen/consumer?

13. Much innovation is technology-driven, and sometimes there are opinions that technological progress is not always to the benefit of mankind. Is this view present in Norway, and how is it dealt with in Norwegian policy?

14. In Denmark, there is currently a lot of discussion about user-driven innovation.

a) Is this term discussed in Norway, too?

b) What is the role of user driven innovation as compared to technology-driven innovation?

c) Does user-driven innovation play a role in Norwegian innovation policy?

15. Successful innovation involves reconciling technological progress with the needs and wants of people who may be customers for new products resulting from the technological progress. In other words, the commercialization of innovation involves the acceptance of new products on the market.

a) To which extent does Norwegian innovation policy deal with this commercialization aspect of innovation?

16. This interview is part of a project dealing with innovation as a possible topic of consumer policy. In your opinion, can innovation be a topic for consumer policy? If yes, how should consumer policy deal with it?

a) In terms of affecting companies?

b) In terms of helping consumers?

c) In terms of addressing the interface between consumers and companies?

d) In terms of other actors like research institutions? 



\section{Appendiks C: Pjece om forbrugerdrevet innovation rettet til virksomheder ${ }^{15}$}




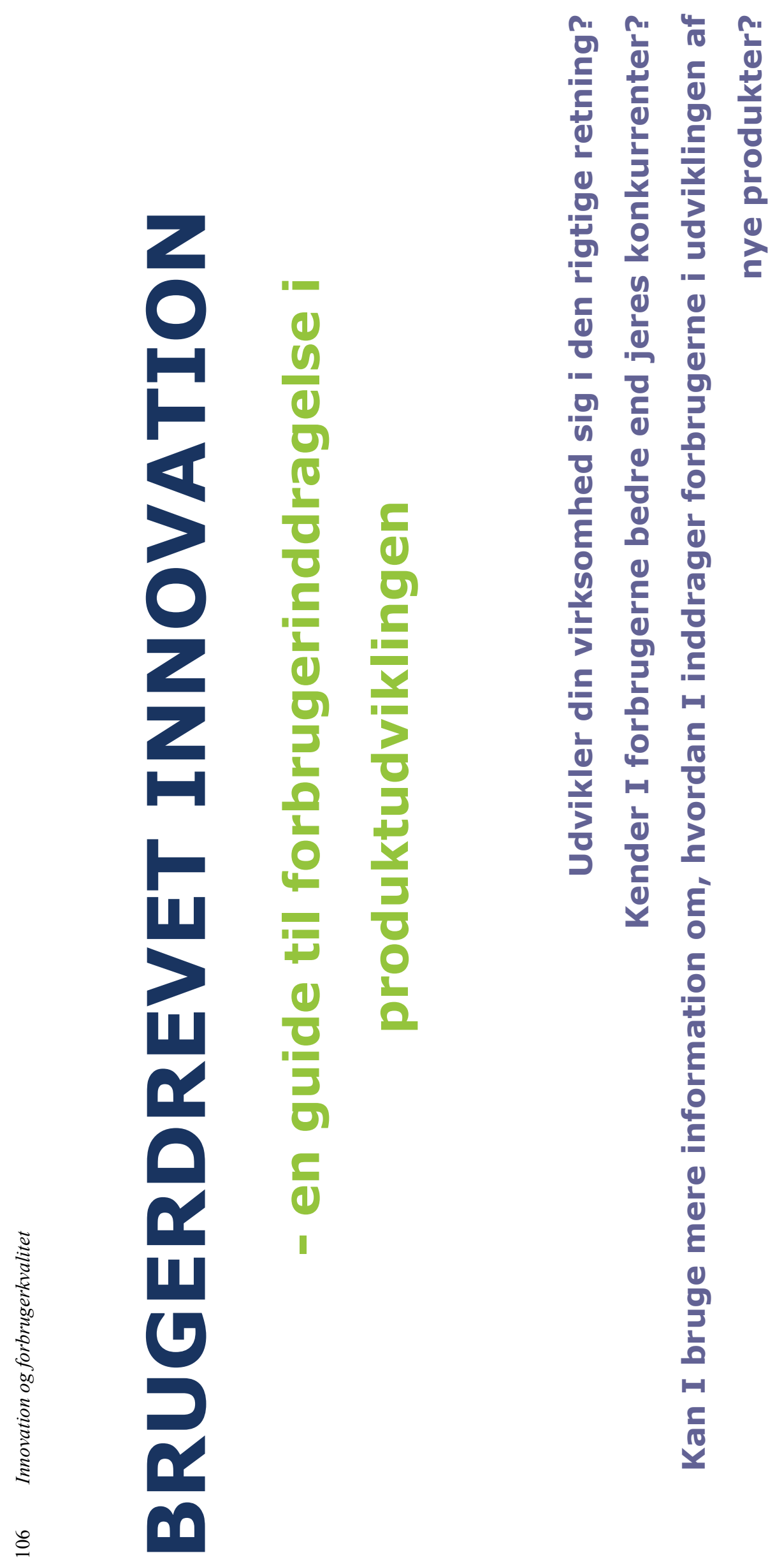


๓ำ ป

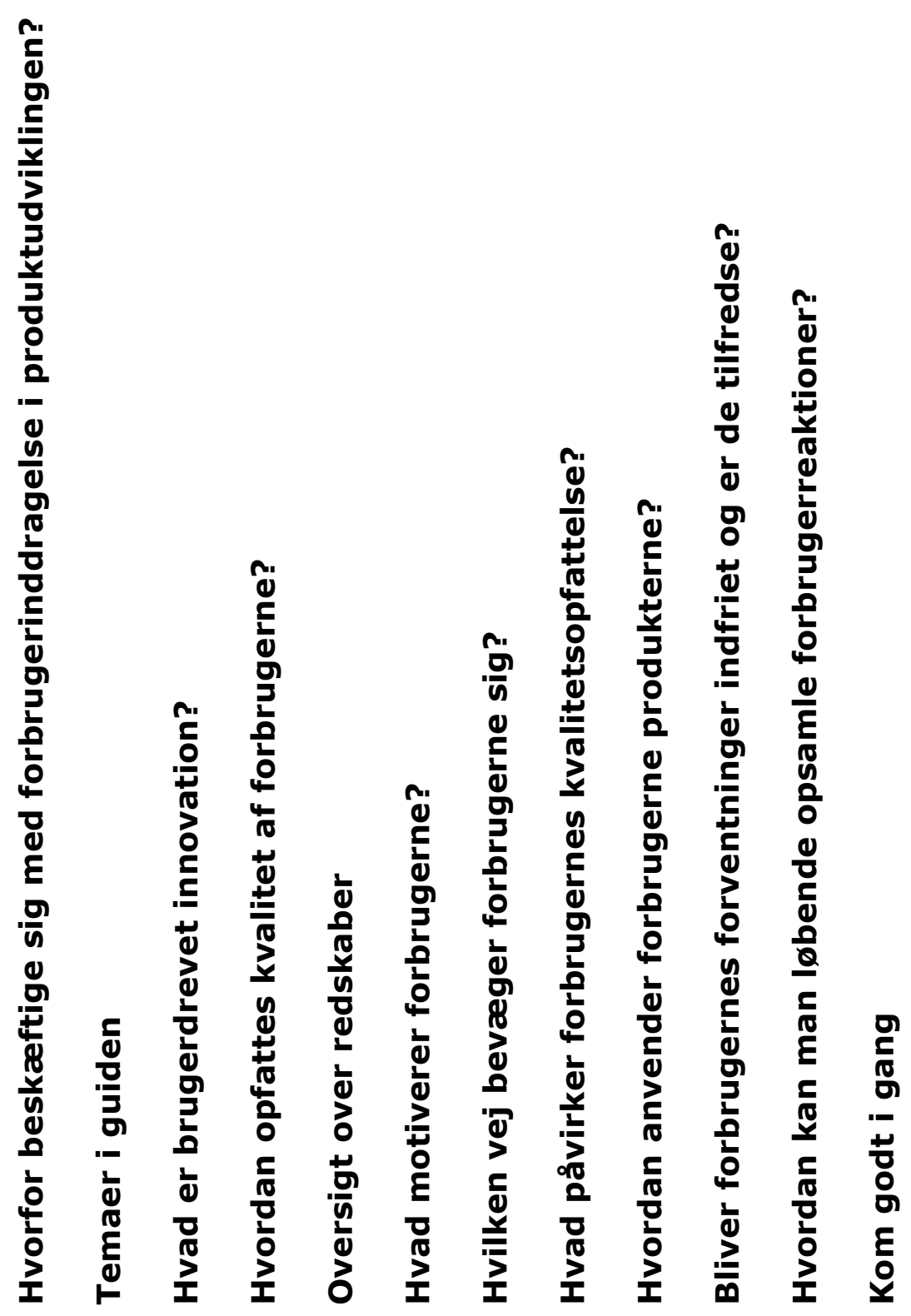




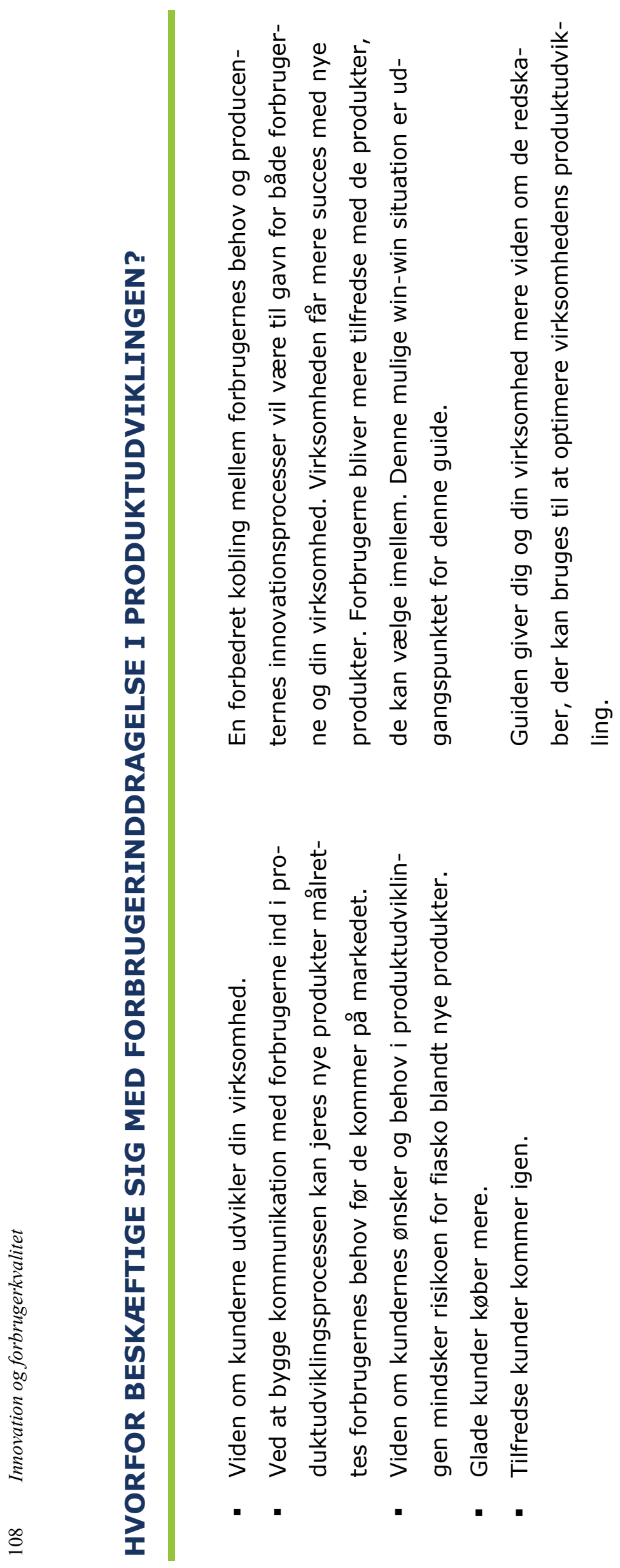



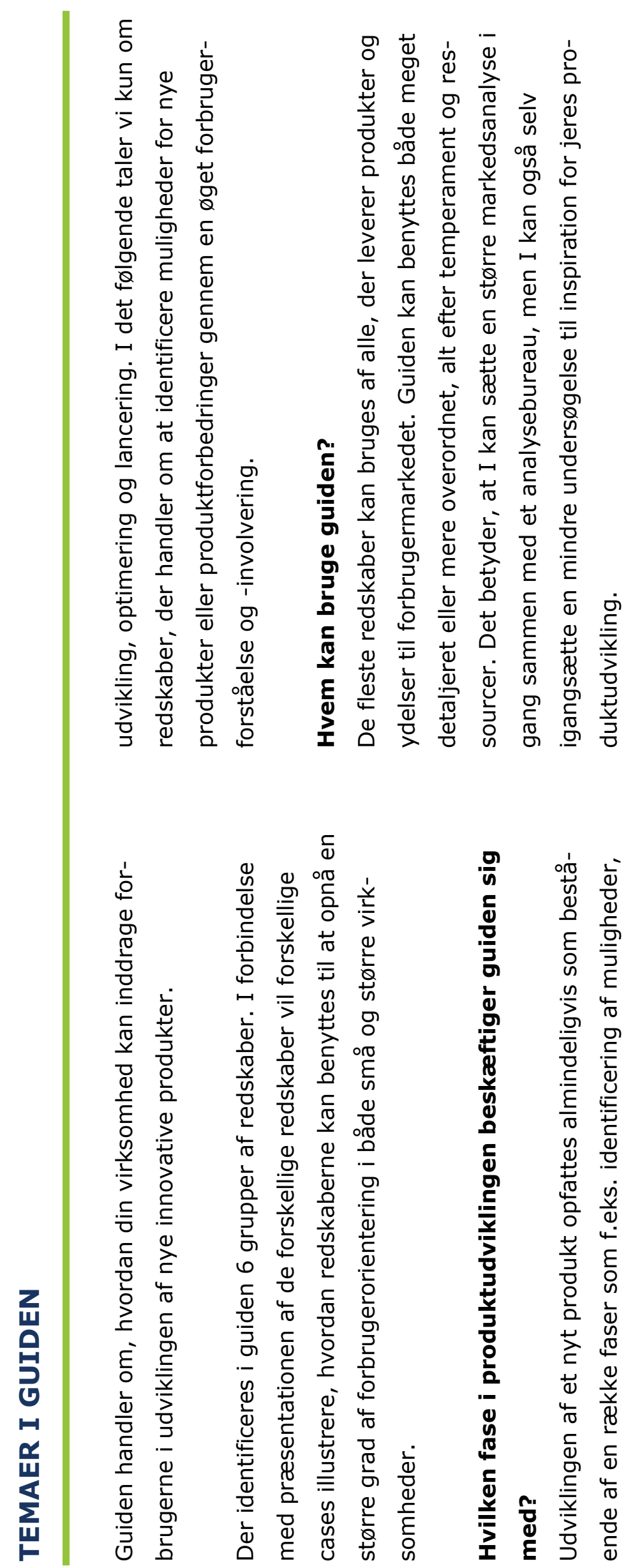


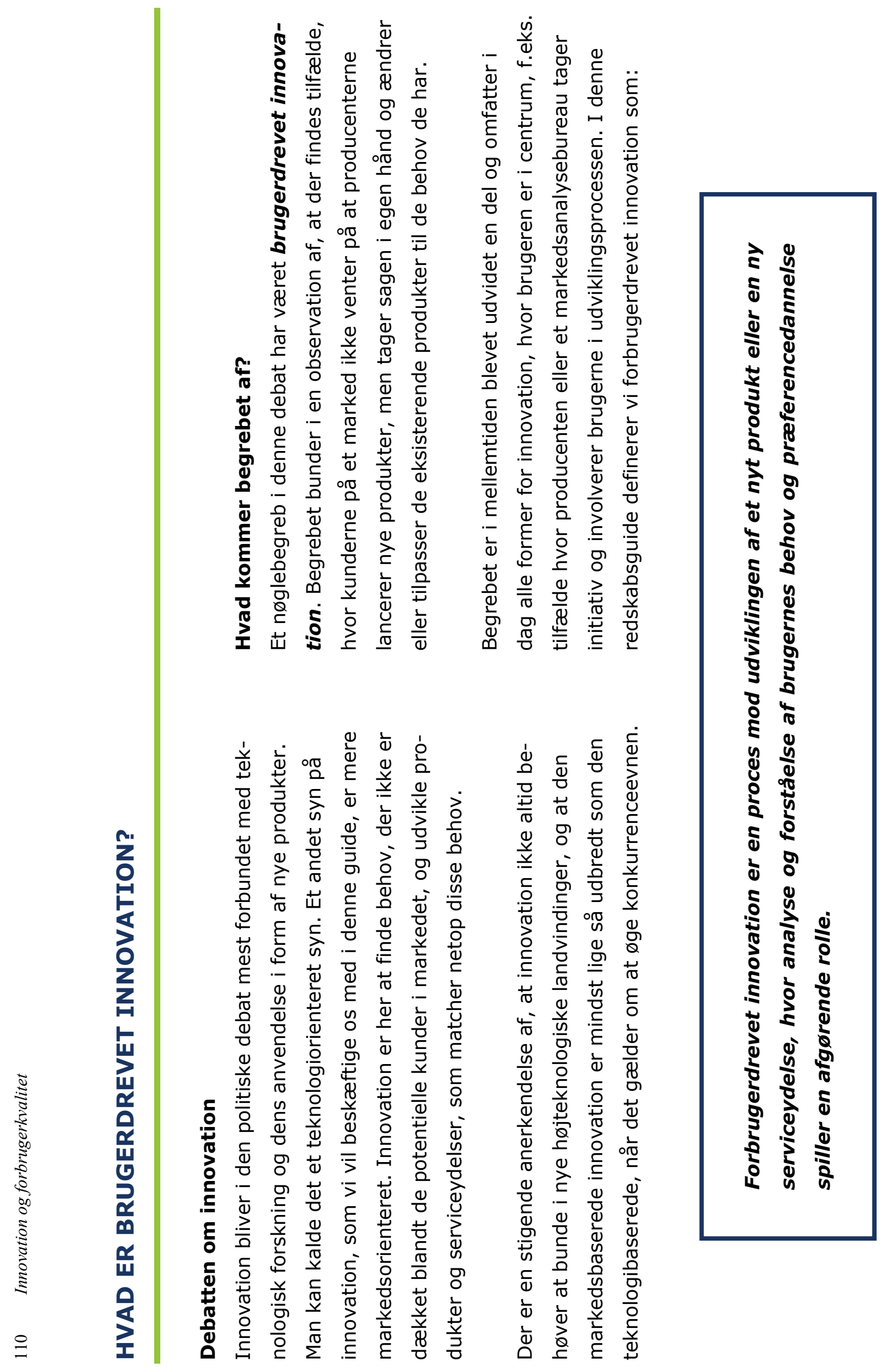




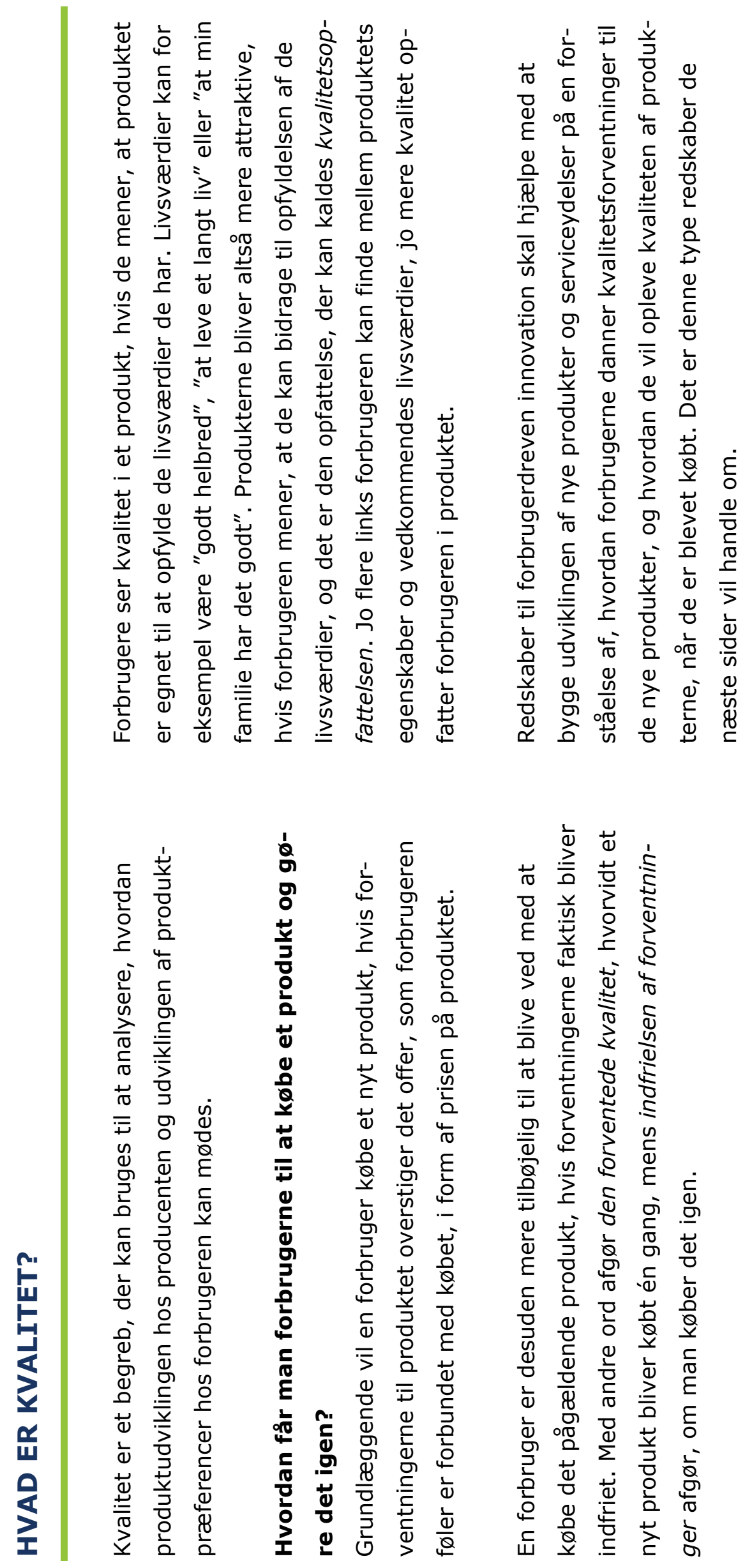




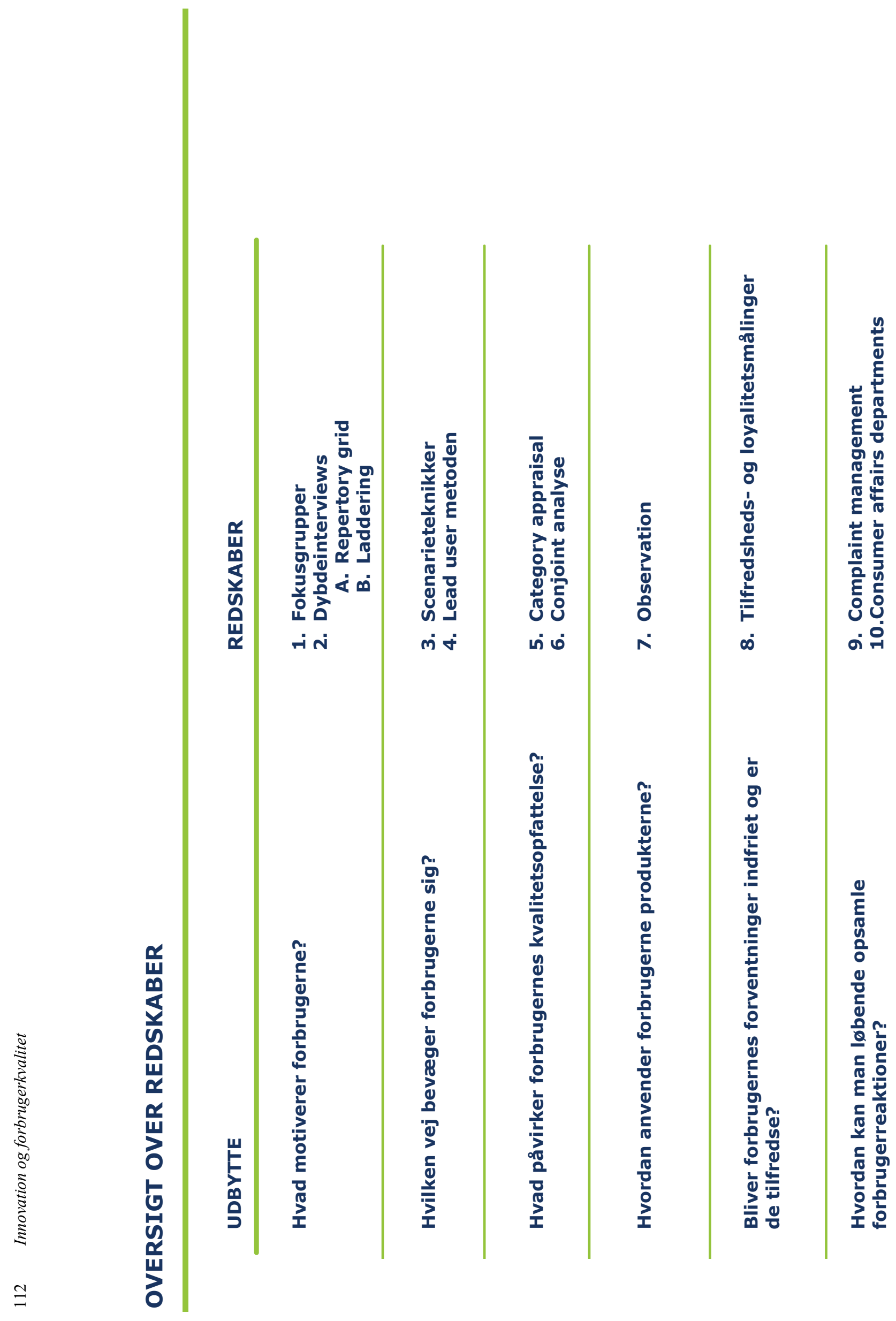




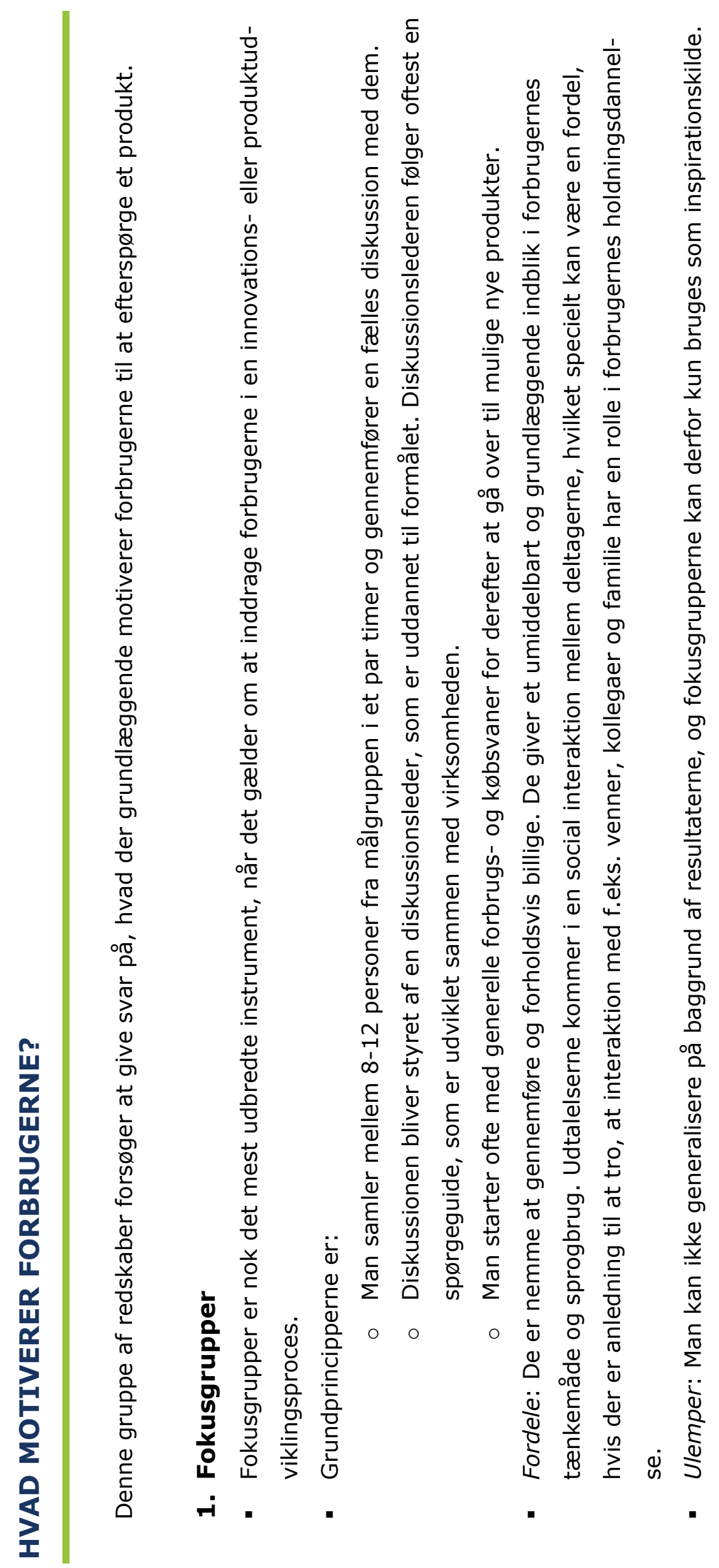




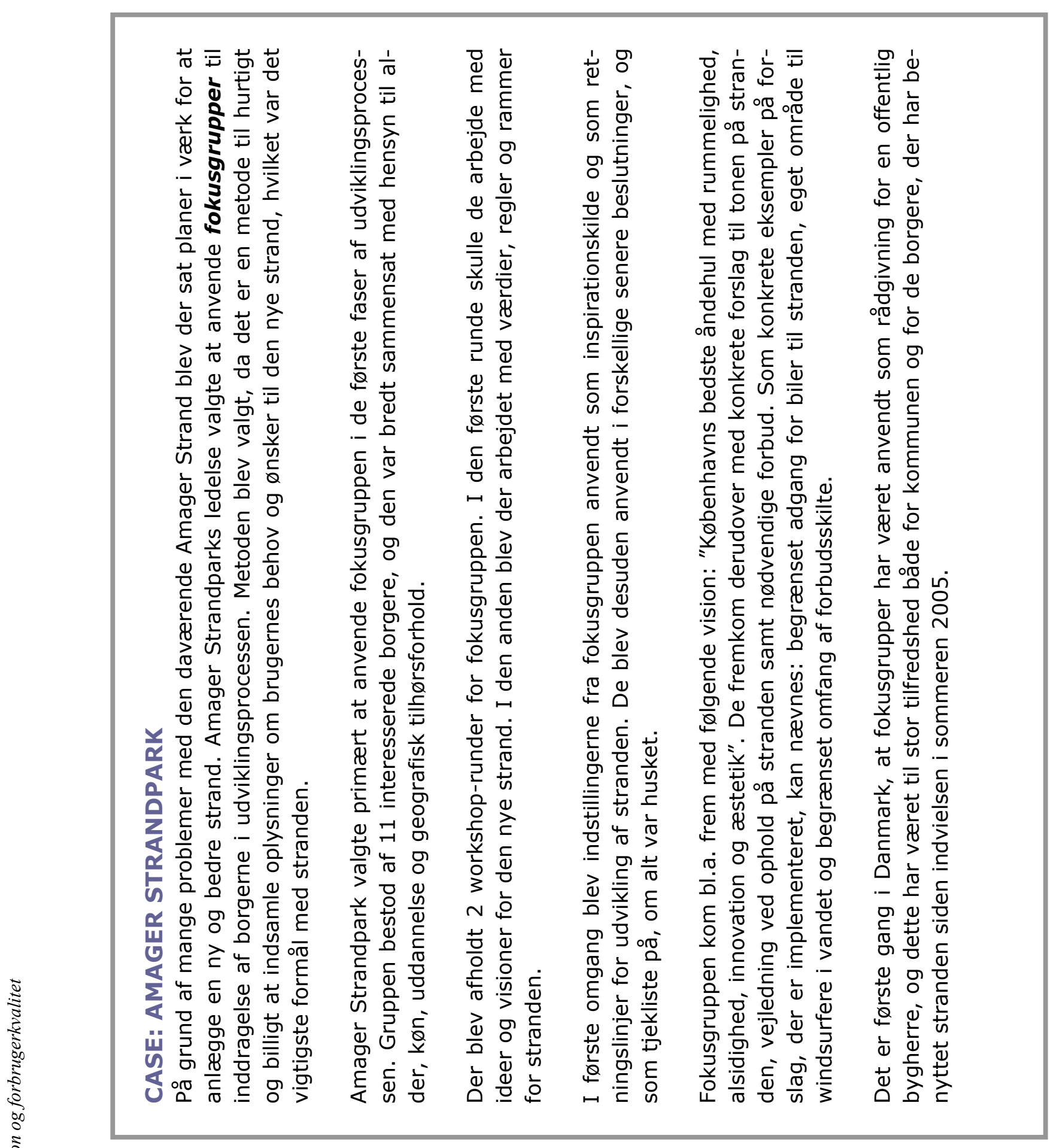




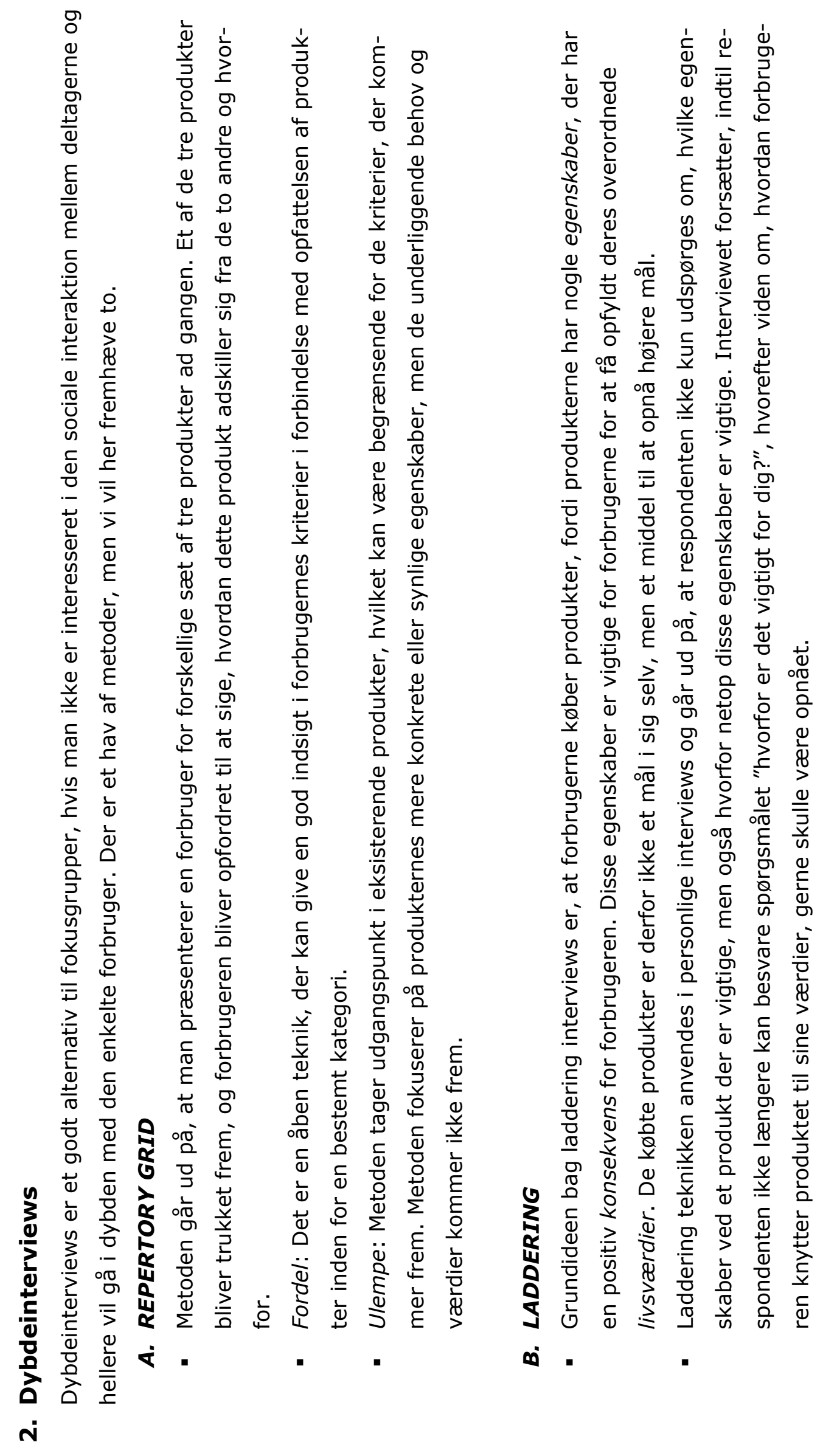


든

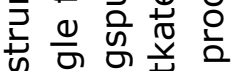
ब

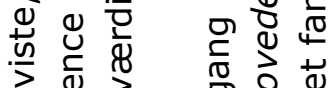

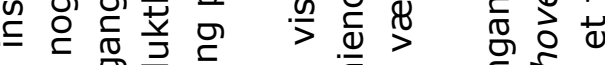

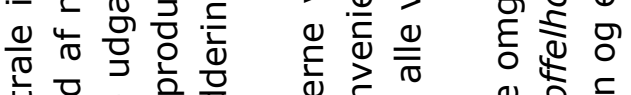
可 \&

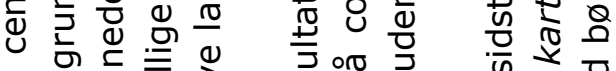

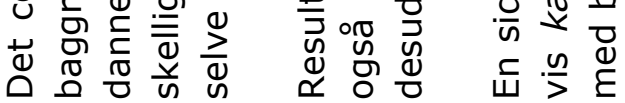




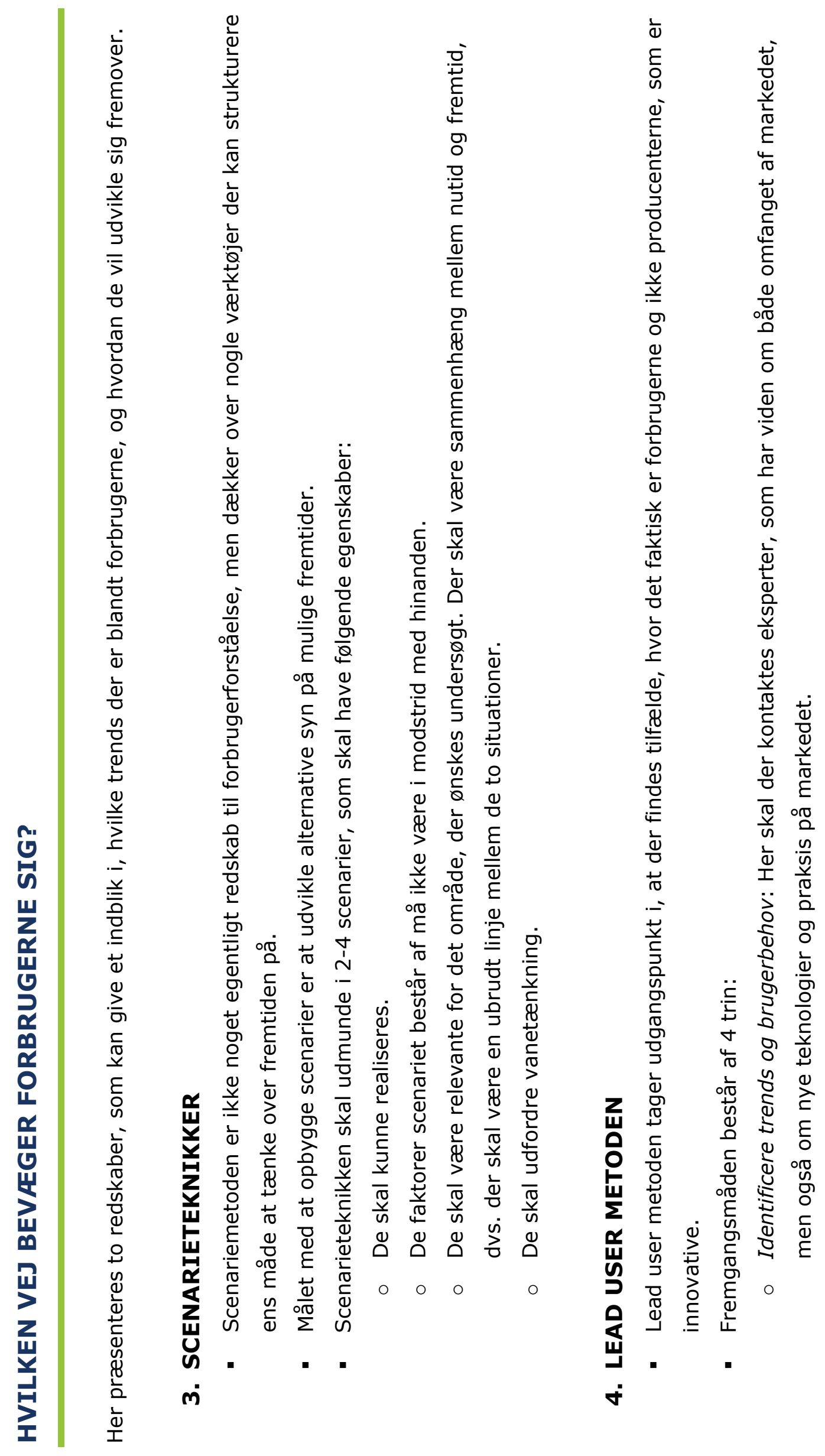




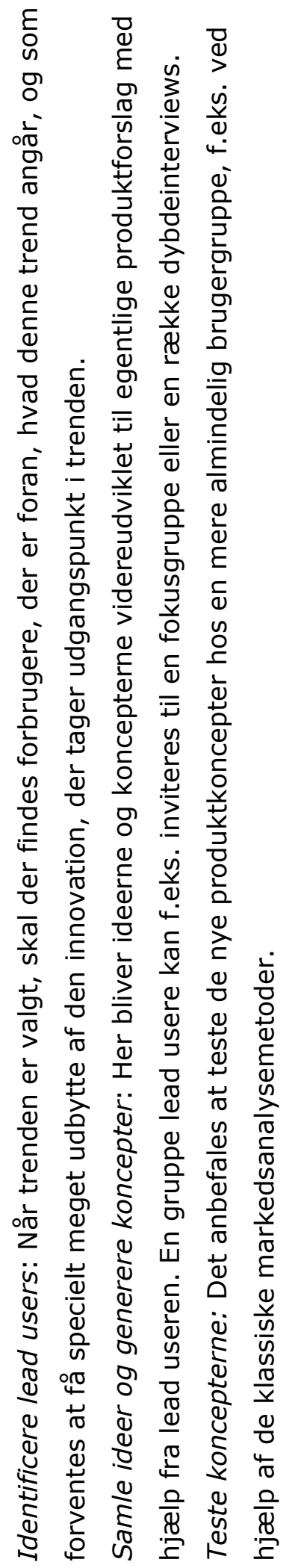

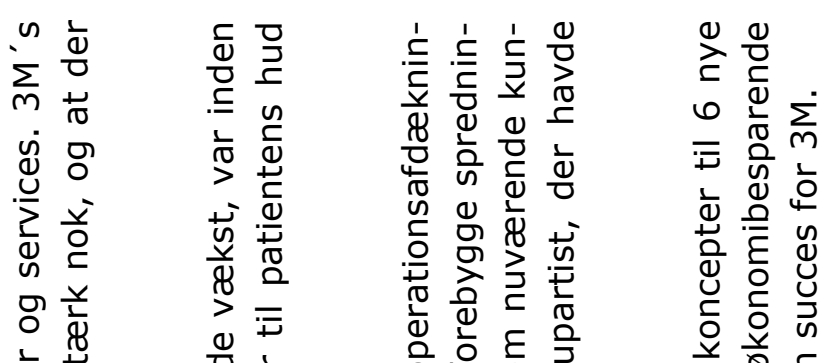

㐫䓠 过 立

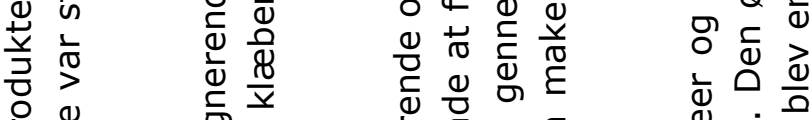

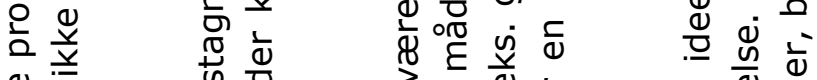

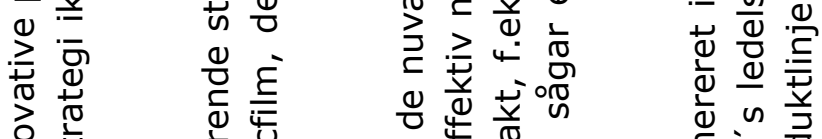

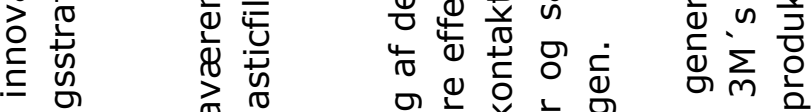

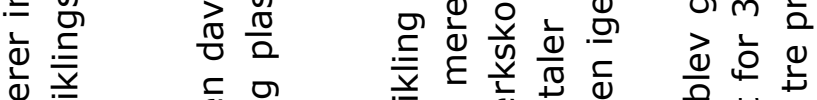

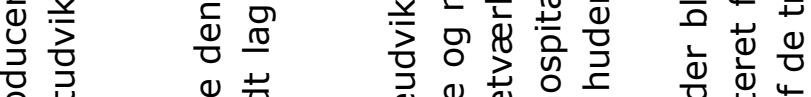

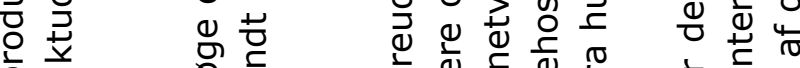

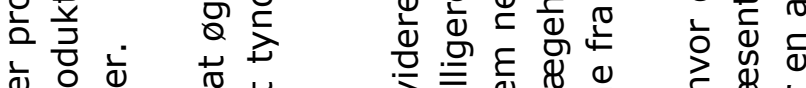

㐫过㐫

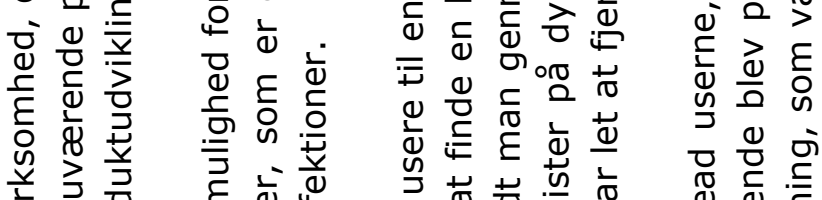

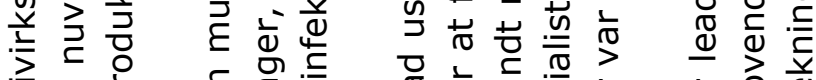

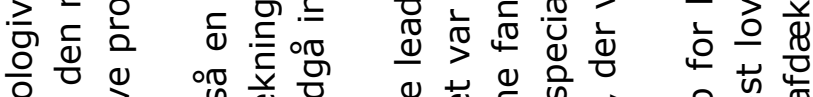

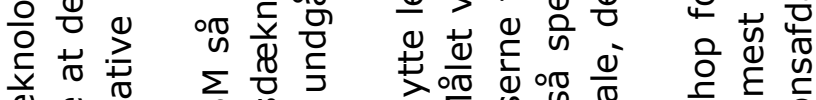

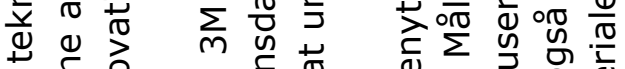

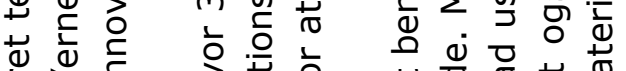

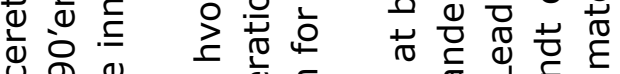

बू ब

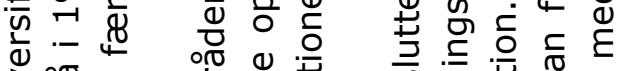

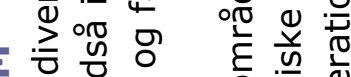

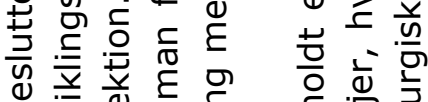

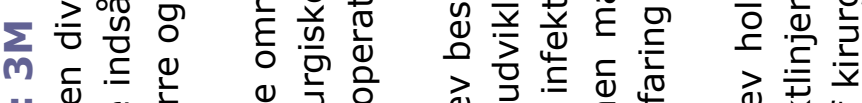

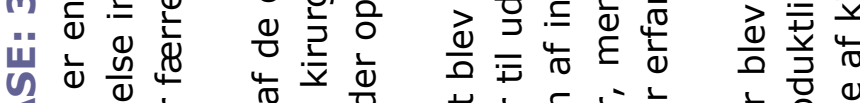

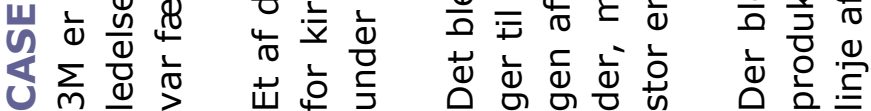




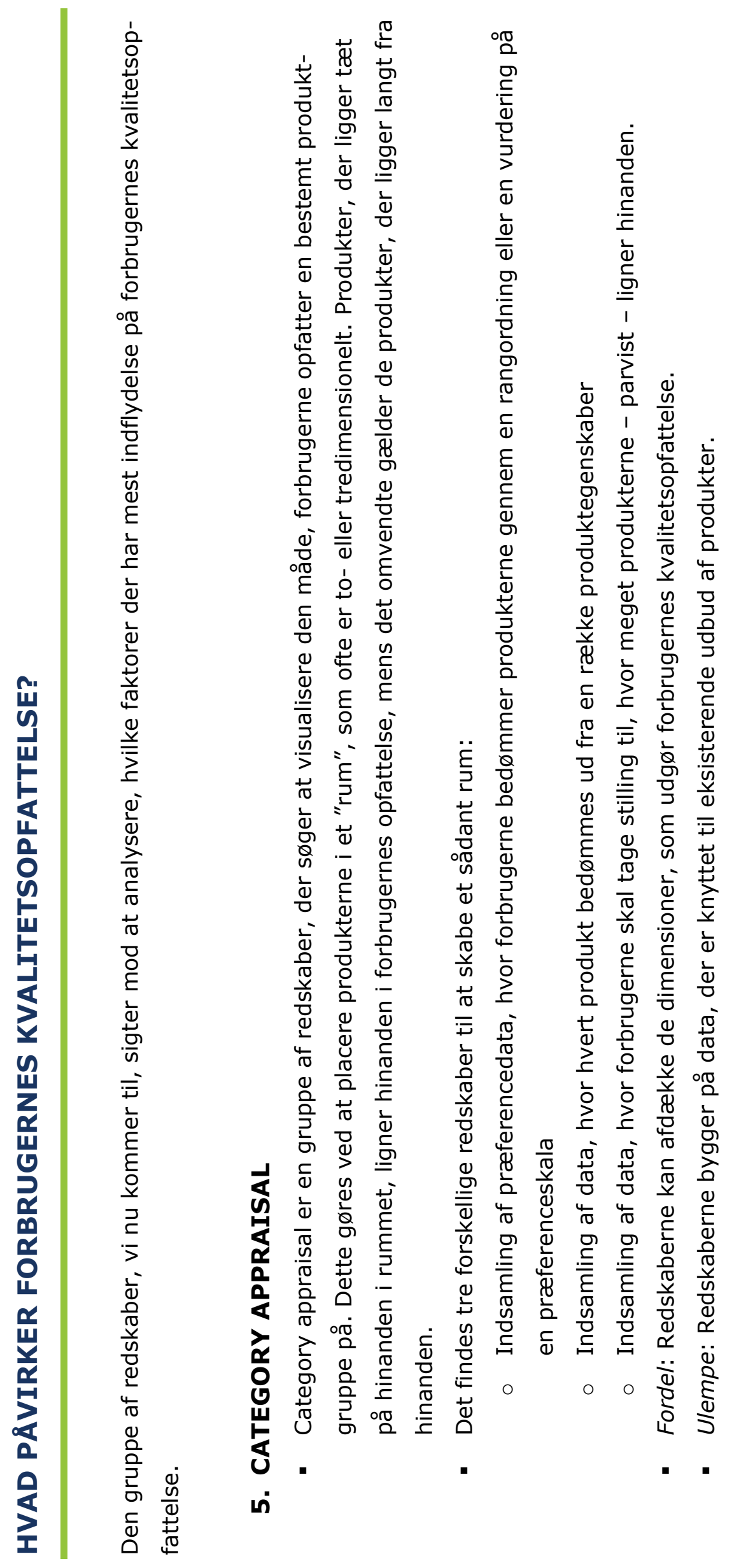




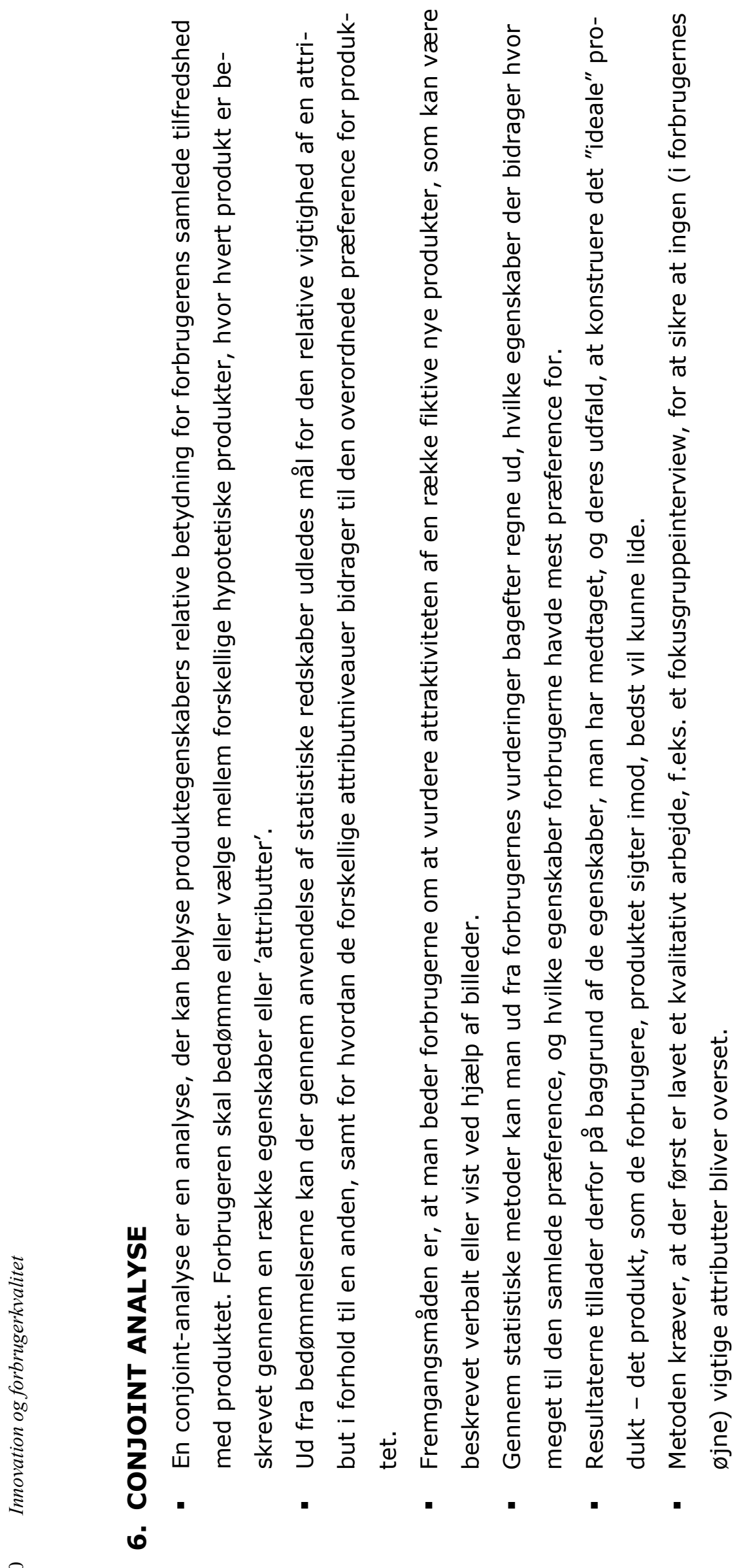




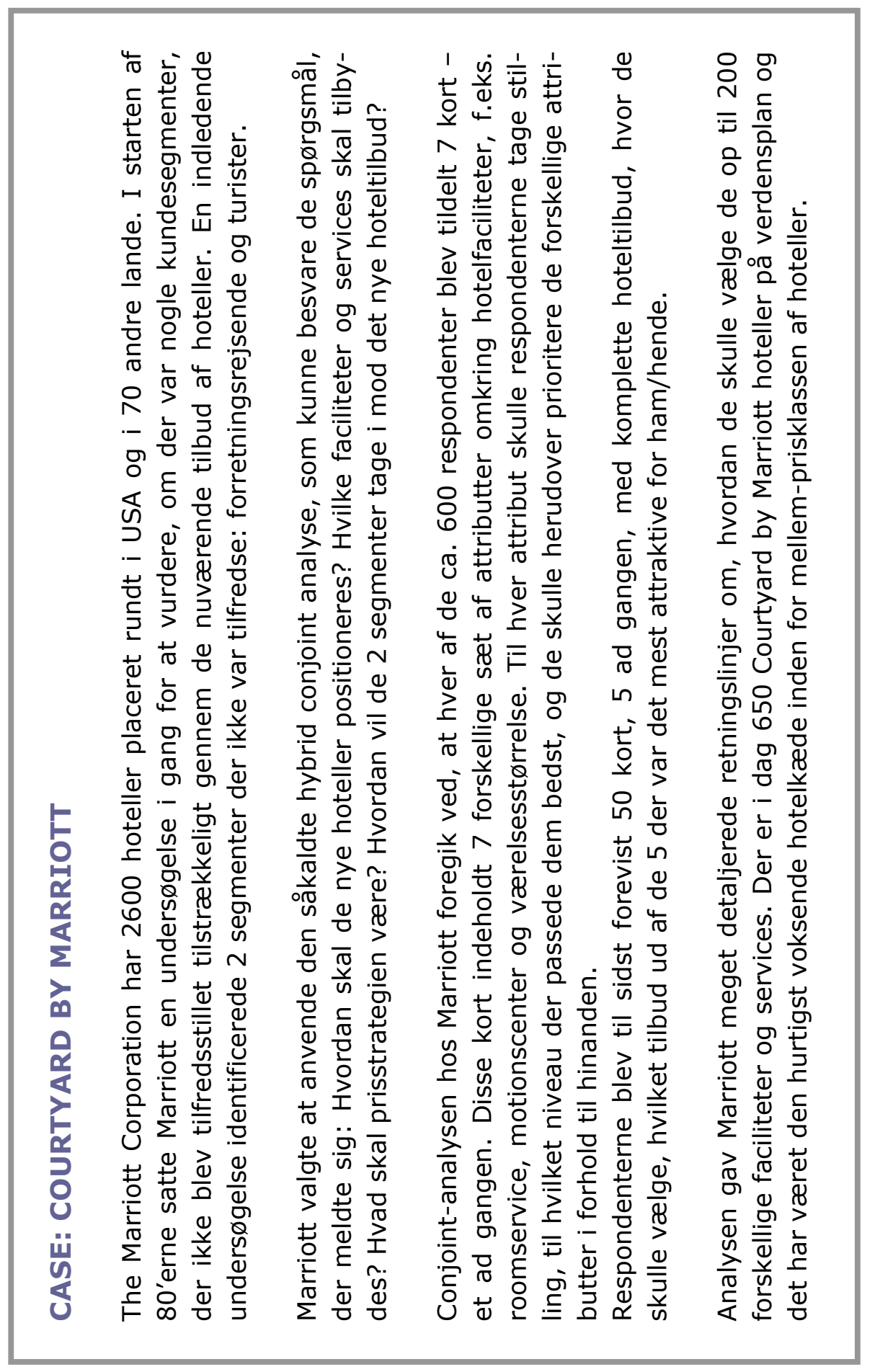




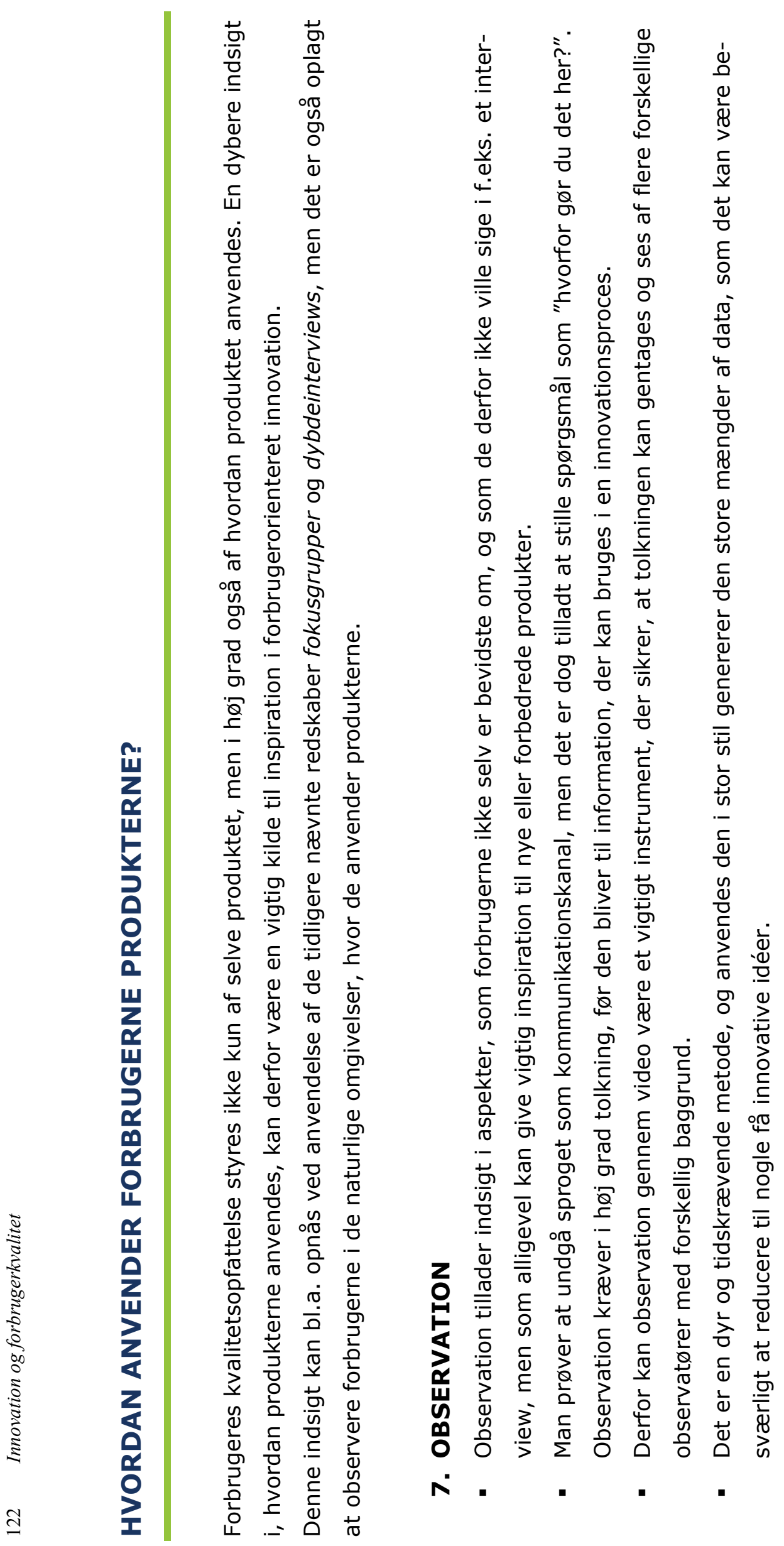




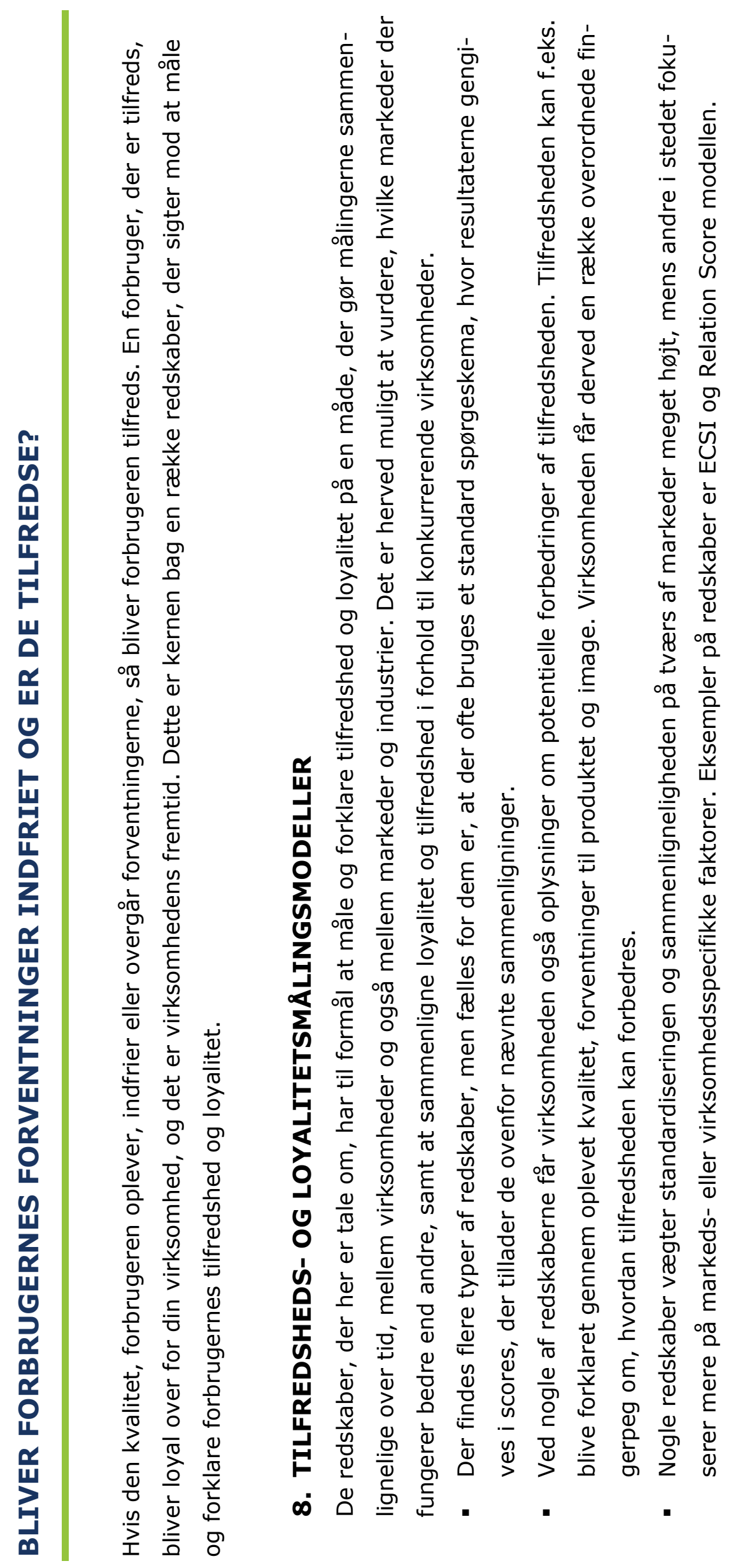




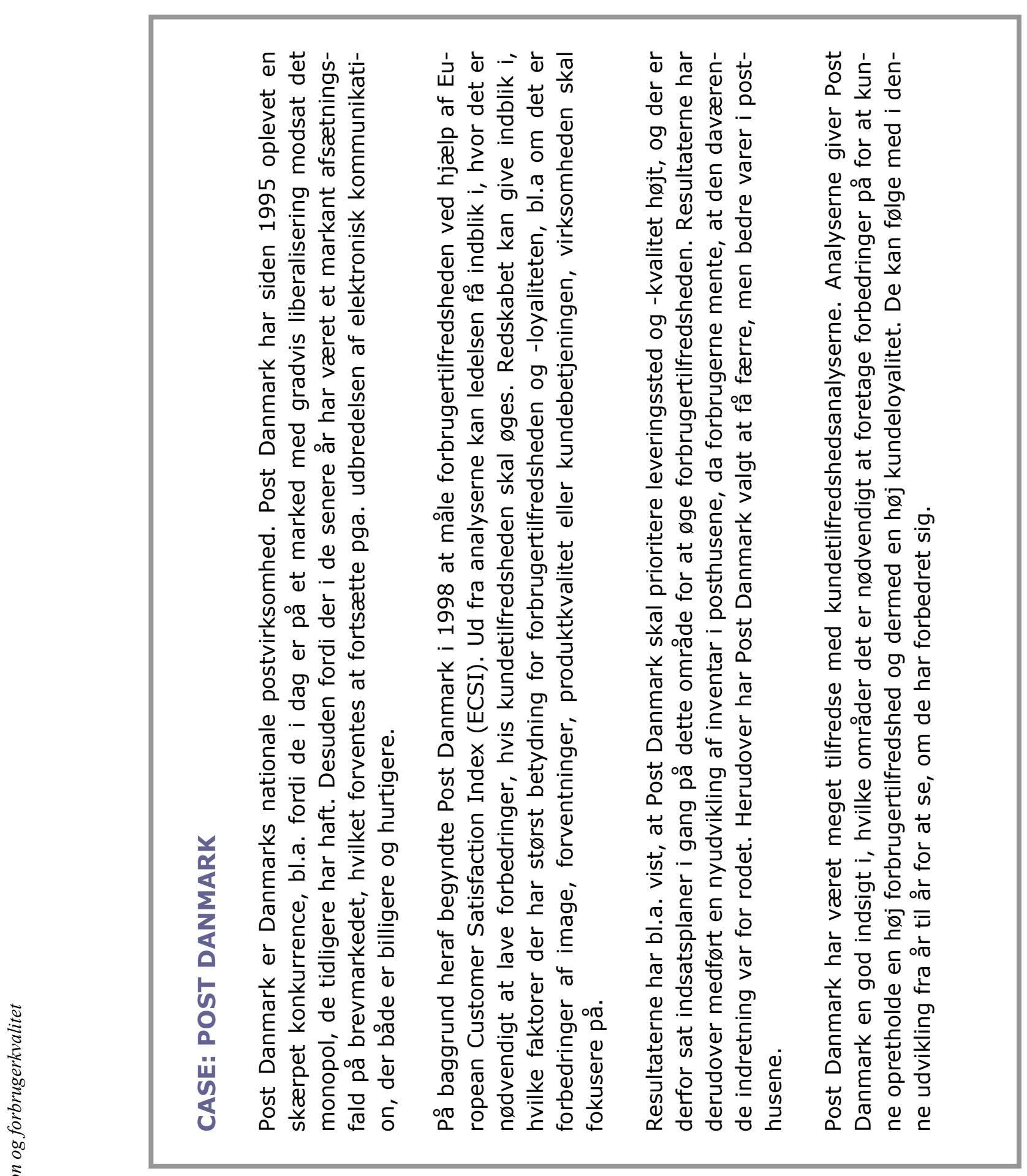




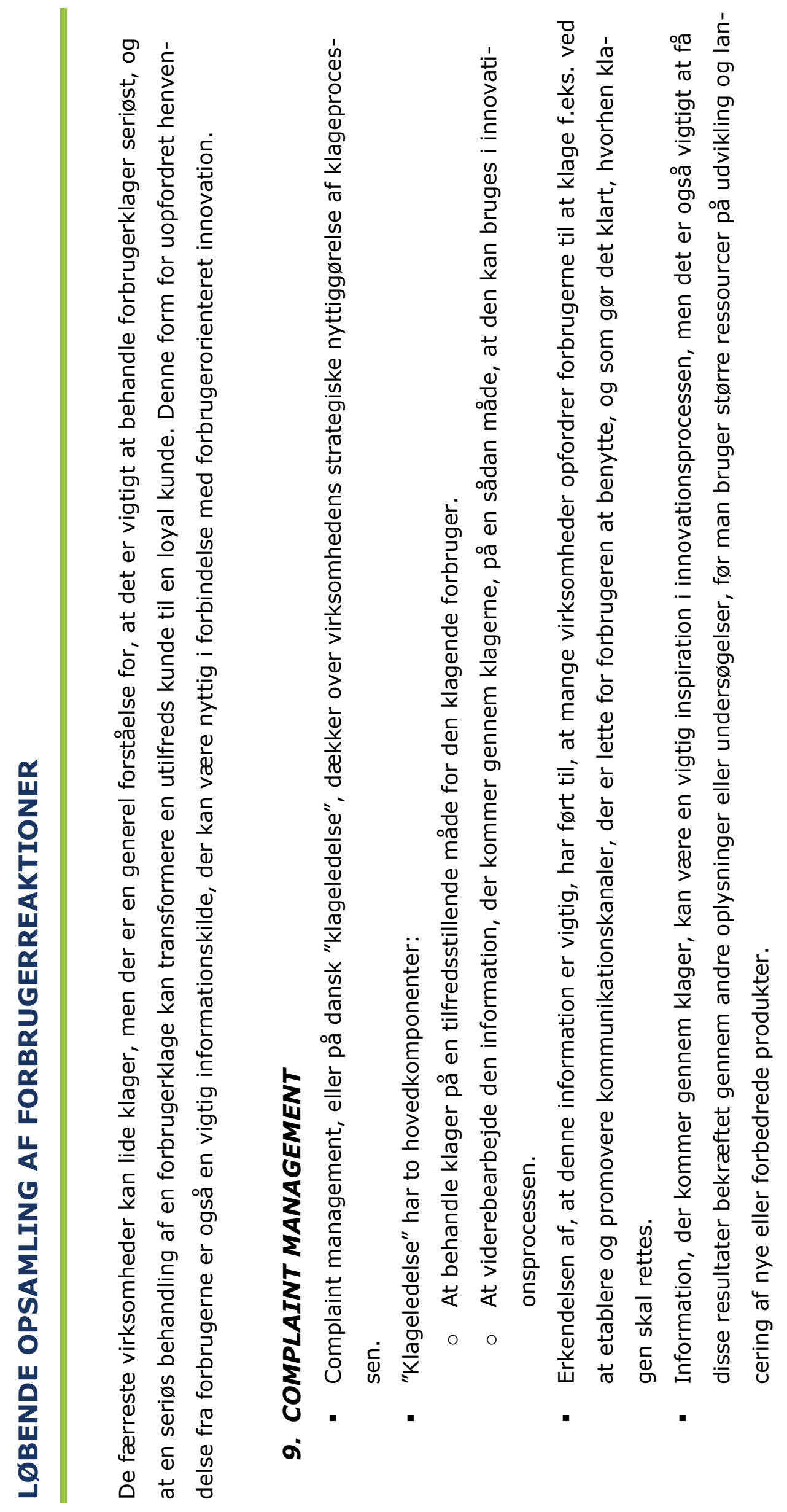




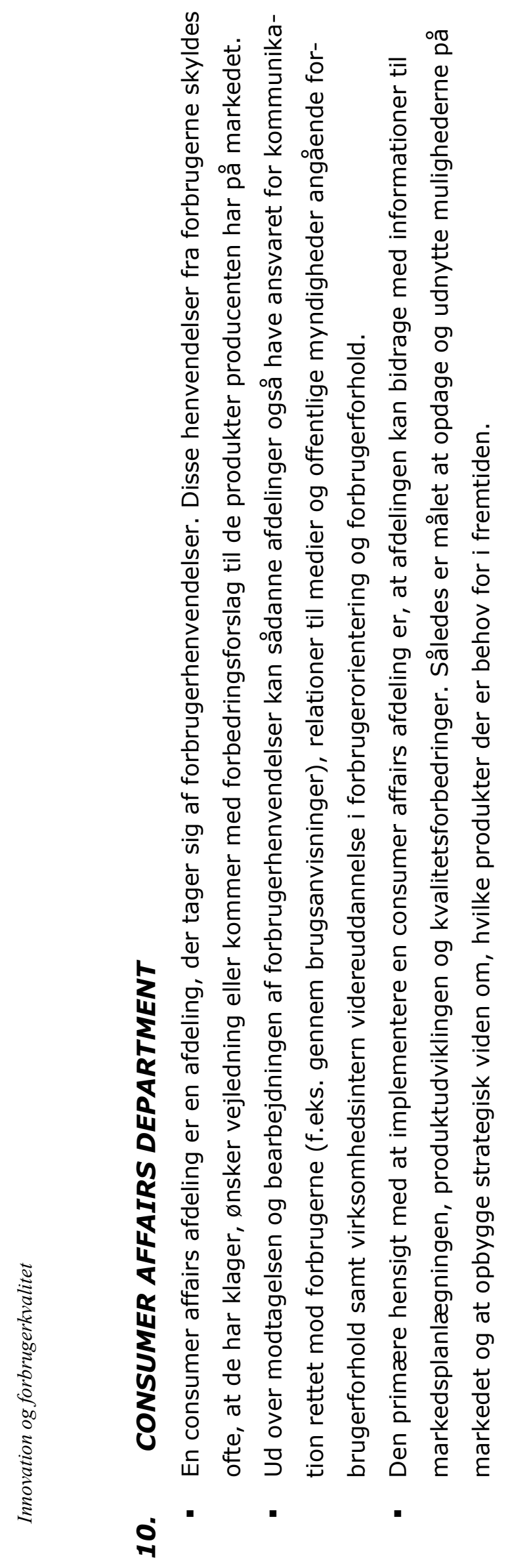




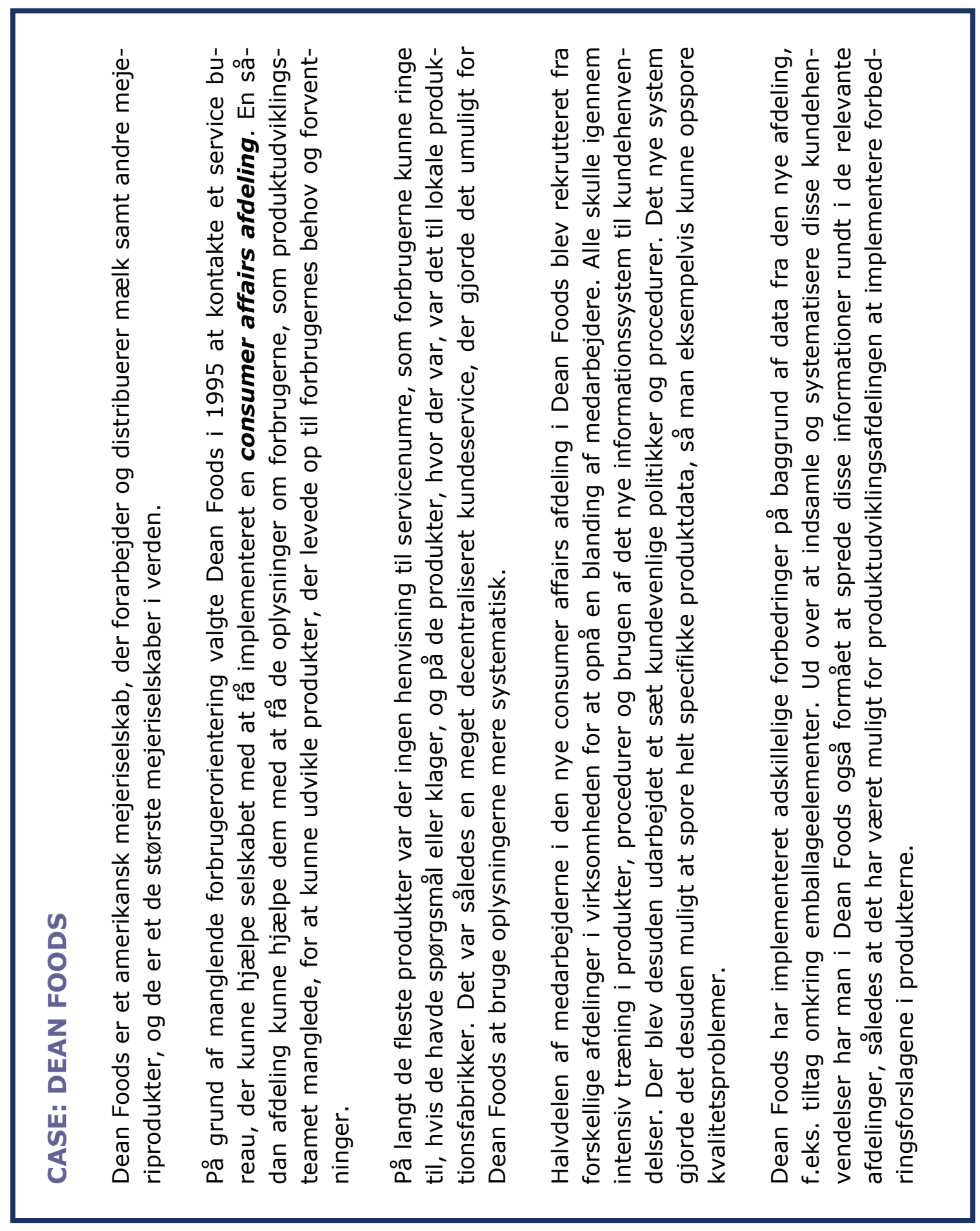




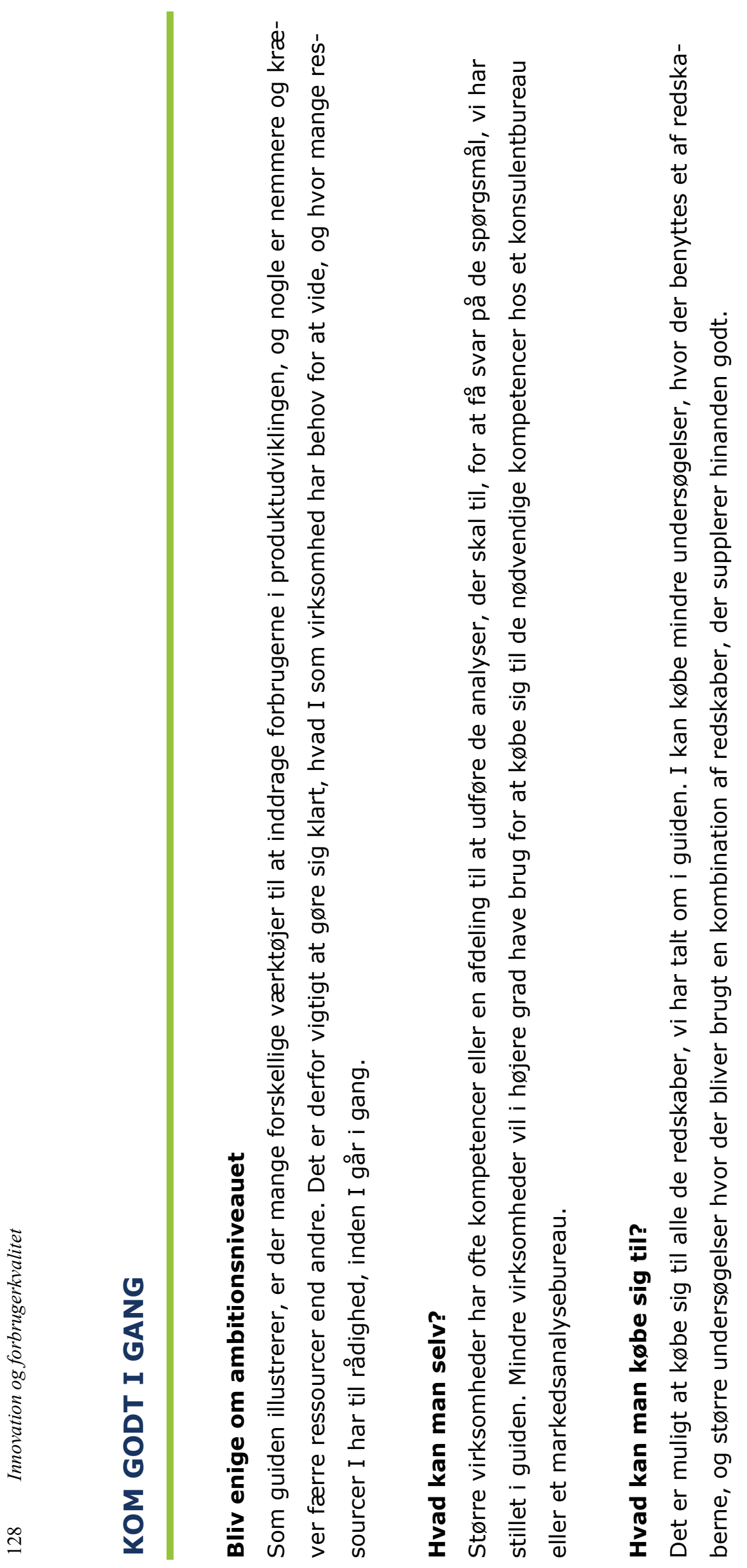




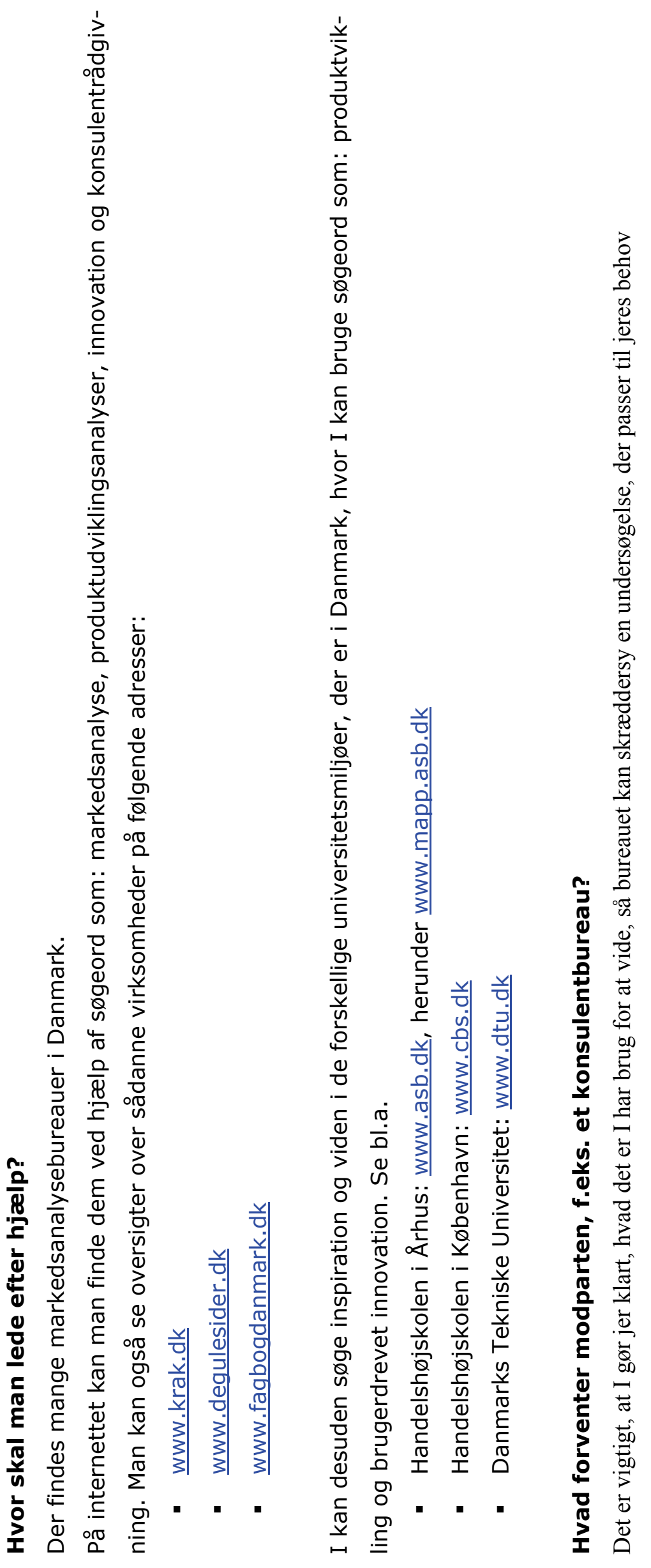

